



\section{TOPLUMSAL DEĞişíM RAPORLARI}

TÜRKIYE'DE SIVIL TOPLUM KURULUŞLARI VE AILE

Doç. Dr. Mehmet Fatih AYSAN

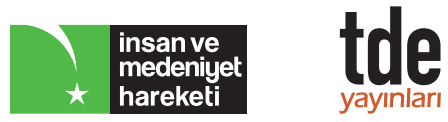




\title{
Proje Yürütücüsü
}

Doç. Dr. Mehmet Fatih Aysan

\author{
Katkıda Bulunanlar \\ Esra Coşkun \\ Ceylan Çıplak \\ Tuba Doğan \\ Elif Hüma Doğruel \\ Esma Küçükbay \\ Elif Sabır \\ Beyza Şahin \\ Elif Yalman \\ Elif Nur Yeniçeri
}

Tasarım ve Uygulama

VIC T O RMOR B I S

Yayın Türü

Türkçe E-Rapor

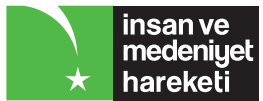

\section{İletişim}

İnsan ve Medeniyet Hareketi

Bahariye Mevlevihanesi, Eyüp Merkez Mahallesi, Silahtarağa Cad. No: 12 Eyüp, İstanbul

Telefon: +90 (212) 501-3171 Web: http://toplumsaldegisim.com

Elektronik posta: admin@toplumsaldegisim.com 


\section{İlk Söz}

Toplumsal Değişim Enstitüsü kurulduğu günden bu yana pek çok akademik faaliyete imza atmıştır. Faaliyete geçirdiği atölyeler kapsamında öncelikli amaç toplumsal değişim kavramının güncel literatür bağlamında nitelikli değerlendirmesini yapmak ve kavramın özgün bir yorumunu akademi ile buluşturmaktır. Atölye çıktıları olarak hazırlanan raporlarda Türkiye İstatistik Kurumu gibi resmi ve gayrı resmi kurumlardan edinilen veriler kullanılmakta ve rapor çıktıları toplumun değişim tecrübesine katkı sağlamaktadır. Bu minvalde Aile, Din, Eğitim, Kent, Göç ve Siyaset temalarında yürütülen çalışmaların çıktıları rapor dizisi haline getirilip okuyucularla buluşturulacaktır. İnsan ve Medeniyet Hareketi bünyesinde faaliyetlerini sürdüren Toplumsal Değişim Enstitüsü olarak modernleşmenin en kritik olgularından bir tanesi olan değişim olgusunu atölyelerimizde hazırladığımız raporlarla yazılı hale getirmek temel çalışma faaliyetlerimizdendir.

Okumakta olduğunuz bu çalışma, enstitümüz bünyesinde faaliyetlerine devam eden, Aile atölyesinin ilk yazılı ürünü olarak ortaya çıkmıştır. Aynı zamanda Toplumsal Değişim Enstitüsü olarak başlattığımız Toplumsal Değişim rapor dizisinin de ilk ürünü olan bu çalışmanın Türk akademisinin tüm üyeleri başta olmak üzere atölyemizin değerli hocası Mehmet Fatih Aysan'a ve atölye katılımcıları kıymetli öğrencilerimize faydalı olmasını ümit ediyorum. Bu vesile ile diğer atölyelerde çalışmalarını sürdüren hocalarımız ve katılımcılarımıza çalışmalarında başarılar diliyorum.

\section{Haluk Nas}




\section{İçindekiler}

Yazarın Özgeçmişi

Sunuş

09

Özet

10

Giriş

STK'lar ve Aile

Veri ve Yöntem

STK'ların Nicel Tasnifi

Mülakat Bulguları

Aile

Kadın ve Anne

Derneklerin Eğitim ve Seminer Faaliyetleri

Aileye Yönelik Tehditler

STK ve Devlet İlişkisi 
Aile ve Kadın

Ailede Baba

58

Türkiye’de Ailenin Güçlü Yönleri

62

STK'lar ve Organizasyonel Yapıları

68

STK'larda Eleştirilen Durumlar

75

SONUÇ VE ÖNERİLER

79

KAYNAKÇA

86 


\section{Yazarın Özgeçmişi}

Doç. Dr. Mehmet Fatih Aysan Marmara Üniversitesi Sosyoloji Bölümü öğretim üyesidir. 2011 yılında University of Western Ontario'da sosyoloji doktorasını tamamlamış, yine aynı üniversitede 2010-2012 yılları arasında öğretim görevlisi olarak dersler vermiştir. Mehmet Fatih Aysan, İstanbul Şehir Üniversitesinde 2012-2020 yılları arasında Sosyoloji Bölümü öğretim üyesi ve 2016-2020 yılları arasında Sosyal Bilimler Enstitüsü müdürü olarak görev yapmıştır. Temel ilgi alanları demografi, aile, iktisadi sosyolojisi ve sosyal politikalar olan Aysan'ın çalışmalarının merkezini iş piyasası, nüfus yapısı, sosyal politikaların toplum refahı üzerindeki etkileri oluşturmaktadır. Aysan'ın araştırmaları; TÜBA, Avrupa Birliği, IDRC, ve TÜBİTAK tarafindan desteklenmiş olup çalışmalarından bazıları Routledge, Palgrave, Springer, Population \& Development Review, Canadian Journal of Sociology ve Emerging Markets \& Finance gibi dergi ve yayınevlerinde yayımlanmıștır. 


\section{Sunuş}

Bu rapor Toplumsal Değişim Enstitüsü bünyesinde faaliyet gösteren Aile Atölyesi'nin uzun soluklu çalışmasının bir ürünüdür. Yaklaşık dokuz ay boyunca gerçekleştirdiğimiz okumaların, tartışmaların, sahadaki mülakatların ve sonunda bunların tamamının yazıya dökülmesinden oluşmaktadır. Bu çalışmanın mülakat ve yazım aşamasında atölye katılımcıları Esra Coşkun, Ceylan Çıplak, Tuba Doğan, Elif Hüma Doğruel, Esma Küçükbay, Elif Sabır, Beyza Şahin, Elif Yalman ve Elif Nur Yeniçeri'nin önemli katkıları vardır.

$\mathrm{Bu}$ çalışma aileye ve sivil topluma dair ortak bir çalışma yapılması arzusuyla başlamış; mülakatlar yapıldıkça aile odaklı sivil toplum kuruluşlarını incelemenin ne kadar önemli olduğu daha net görülmüştür. Mülakat ve gözlemler, atölye katılımcılarının tamamının veri toplama sürecine dâhil olmasını sağlamıştır. Haftalık toplantılarda tartışılan mülakat bulguları analizlerin daha rafine hale getirilmesini kolaylaştırmıştır.

Bize kapılarını açan sivil toplum kuruluşlarına, kısıtlı vakitlerini ayırıp aile ve sivil topluma dair değerli görüşlerini paylaşan STK temsilcilerinin her birine ayrı ayrı teşekkür ederiz. Onların ilgisi ve özverili katkıları olmasaydı bu çalışma gerçekleşemezdi. Bu süreçte Aile Atölyesi'nden desteğini esirgemeyen ve bu çalışmanın gerçekleşmesini sağlayan İnsan ve Medeniyet Hareketi'ne, Toplumsal Değişim Enstitüsü ve onun direktörü Haluk Nas Bey’e teşekkürü bir borç biliriz.

Doç. Dr. Mehmet Fatih Aysan 


\section{Özet}

Yaşanan hızlı sosyal değişimler bir yönüyle aile yapısındaki değişimleri tetiklerken diğer taraftan ailenin dönüşümü de sosyal değişimin hızlanmasına neden oluyor. Bu baş döndürücü değişim furyası doğal olarak sivil toplumun da dönüssmesine, aile odaklı hizmet veren kurumların odaklarının ve faaliyetlerinin yeniden şekillenmesine neden oluyor. Diğer taraftan son yirmi yıldır devlet yapılanmasının ve uluslararası gelişmelerin de katkısıyla devlet-sivil toplum, devlet üstü güçler-sivil toplum ve sivil toplum-sivil toplum ilişkileri de dönüşüm içine giriyor.

Bu çalışma, aile merkezli çalışan sivil toplum kuruluşlarının genel yapısını ve aile kurumu üzerine görüsslerini inceleyerek sivil topluma ve politika yapıcılara genel politika önerileri getirmeyi amaçlar. Bu amaç doğrultusunda nitel ve nicel yöntemler kullanılarak veriler toplanmış ve bunların analizi yapılmıştır. Araştırmanın nicel kısmında aile merkezli çalışan dernek ve vakıfların listesi T.C. İçişleri Bakanlığı ile T.C. Vakıflar Genel Müdürlüğü'nün verileri çerçevesinde tasnif edilmiştir. Çalışmanın ikinci aşamasında Kasım 2018 ile Nisan 2019 tarihlerinde aile merkezli çalışan 20 sivil toplum kuruluşunun yöneticisi ve üst düzey temsilcisiyle yarı yapılandırılmış derinlemesine mülakatlar yapılmıştır. 
Araştırma bulguları şu şekilde özetlenebilir:

* Veri toplanan STK'ların önemli bir kısmında kurumsallaşma adına sıkıntılar yaşanmaktadır.

* Birçok kurum finansal olarak sürdürülebilmekte zorlanmaktadir.

* Birçok STK'nın net olarak tanımlanmış, sınırları belli bir faaliyet alanı yoktur.

* Kurumların bazılarında genç kalifiye gönüllü bulmakta s1kıntılar yaşanmaktadır.

* Özellikle son yıllarda birçok STK, devlet ve uluslararası kurumlarla yakın ilişkiler geliştirmektedir.

* Diğer STK'larla yapılan iş birlikleri istenilen düzeyde değildir.

* Erkeklerin aile ve ilgili alanlarda sivil toplum faaliyetlerine katılımı oldukça düşüktür.

* Geleneksel aileye ve aile değerlerine karşı artan tehditler olduğu birçok katılımcı tarafindan vurgulanmıştır. Katılımc1ların önemli bir bölümü artan boşanmalar, Türk aile geleneğinde olmayan farklı birlikteliklerin ortaya çıkışı, demografik yaşlanma, sosyal medya, aile içi ilişkileri temel sorun alanı olarak ifade etmişlerdir.

* Aile ve çocuklar ile ilgili konularda kadının yalnız bırakılması sıklıkla dile getirilmektedir.

* Çalışmaya katılan tüm sivil toplum temsilcileri her türlü aksaklıklarına rağmen aileyi ve onun bireyi koruyucu özelliğinin toplumumuzun en güçlü yönlerinden biri olduğunu ve ailenin korunması gerektiğini vurgulaması ailenin korunması ve güçlendirilmesine dair politikaları gündeme getirmektedir. 
Mülakat bulguları ışığında aile ve sivil toplum kuruluşlarına dair genel öneriler aşağıdaki gibi sıralanabilir:

* $\quad$ Aile kurumunun toplumun önemli bir parçası olduğu unutulmadan toplumsal değişimin getirdiği firsatlar ve riskler doğru anlaşılarak değişen toplumun ve ailenin ihtiyaçlarını dikkate alan politikalar ve faaliyetler geliştirilmelidir.

* Ailenin anne, çocuk, yaşlı demeden bir bütün olduğu ve ailedeki fertlerin tamamının ihtiyaçlarını dikkate alan bütüncül planlamalarla faaliyetlerin yapılması gerektiği unutulmamalıdır. Bu bütüncül politikalara ek olarak engelli, tek ebeveynli, yaşlı, yoksul vb. dezavantajlı ailelerin ihtiyaçlarını gözeten özel faaliyetler de ihmal edilmemelidir.

* STK'larda gönüllülük ruhu zedelenmeden bu kurumların profesyonelleşmesi önemlidir. Bunun için gerekli olan kurumsal altyapının sağlanması gerekmektedir.

* STK'ların finansal olarak sürdürülebilir hale gelmesi, kaynaklarını çeşitlendirmesi ve tek bir finansal kaynağa bağlı kalmaması sivil toplum kuruluşlarının sürekliliği için hayati önem taşımaktadır.

* STK'lar her alanda farklı faaliyetler düzenlemek yerine çalışma odaklarını netleştirmeli ve bu odaklarda derinleşmelidirler. Önceden belirlenmiş şeffaf amaçlar doğrultusunda faaliyetler düzenlemeli ve bunların çıktılarını ise sistemli bir biçimde analiz etmelidirler.

* STK'lar kendi aralarında devlet, piyasa ve uluslararası kurumlar gibi paydaşlarla daha etkin iş birlikleri kurmalıdırlar.

* STK'lar kuruluş gayeleri çerçevesinde ulusal ve uluslararası çevrelerde daha aktif lobi faaliyetleriyle aileye dair meselelerde kamuoyu oluşturmalı, sorunlu gördükleri meseleleri gündemde tutmalı ve bu sorunların çözümüne aktif destek sunmalıdirlar. 


\section{Giriş}

Aile kurumu ve ilgili alanlarda hararetli tartışmalar uzun süredir Türkiye gündemini işgal ediyor. Bir başka tartışma konusu alanı ise dernek ve vakıflardır. Hızlı bir sosyal değişimden geçen Türkiye'de bu iki tartışma alanını incelemek; kendisi de hızla dönüşen sivil toplumun aileye dair neler söylediğini, sosyal değişime nasıl cevaplar ürettiğini veya üretemediğini göstermesi açısından oldukça önemlidir.

Yaşanan sosyal değişimler bir yönüyle aile yapısındaki değişimi tetiklerken diğer taraftan ailenin dönüşümü de sosyal değişimin hızlanmasına neden oluyor. Bu baş döndürücü değişim furyası doğal olarak sivil toplumun da dönüşmesine aile odaklı hizmet veren kurumların ihtiyaçlarının, odaklarının ve faaliyetlerinin yeniden şekillenmesine neden oluyor. Diğer taraftan son yıllarda devlet yapılanmasının ve uluslararası gelişmelerin de katkısıyla devlet-sivil toplum, devlet üstü güçler-sivil toplum ve sivil toplum-sivil toplum ilişkileri de dönüşüm içine giriyor.

Günümüz Türkiye'sinde, uzun yıllar boyunca karar alma mekanizmalarından dışlanmış ve devlet kurumlarına şüphe ile bakan muhafazakâr kesimin sivil toplum kurumlarının önemli bir kısmı devlet ile yakın ilişkiler kurarak seküler kabul edilebilecek kurumlara kıyasla önemli destekler elde etmekte ve politika yapımına katkı sunmaktadır.

Bu çalışma, aile odaklı çalışan sivil toplum kuruluşlarının genel yapısını ve aile kurumu üzerine görüşlerini inceleyip bu çerçevede genel politika önerileri getirmeyi amaçlar. Bu amaç doğrultusunda nitel ve nicel yöntemler kullanarak veriler toplanmış ve bunların analizi yapılmıştır. 


\section{STK'lar ve Aile}

Aile ve sivil toplum kuruluşları (STK) üzerine yapılan gerek ulusal gerekse uluslararası çalışma sayısı oldukça azdır. Birçok çalışmada aile bir bütün olarak ele alınmamış, aileyi oluşturan çocuk, kadın, yaşlı gibi belirli grupların refahını etkileyen STK'ların rolleri incelenmiştir. Örneğin, Rosy (2016) insan ticareti mağduru Bangladeşli kadınların topluma tekrar sağlayabilmesinde STK'ların rolünü incelerken Ivica Petrikova (2015) ise El Salvador'da çocuk iş̧̧ilerle çalışan üç STK'nın meseleye bakışını ve faaliyetlerini analiz etmektedir. Sıklıkla aile içi şiddetin önlenmesi ve kadınların statüsünün geliştirilmesinde STK'ların rolleri üzerine çalışmalar mevcuttur (Sloat 2005; Nalini \& Krishnakumar 2017). Bununla birlikte ailenin korunmasında STK'lar ve sosyal hizmet uzmanlarının görevleri üzerine az da olsa çalışmalar vardır (Strydom 2010; Van Huyssteen \& Strydom 2016). Ancak bunlar da STK'ların aile üzerine yaptığı çalışmalardan ziyade sosyal hizmet uzmanlarına odaklanmışlardır.

Türkiye'deki çalışmalar incelendiğinde benzer alanlara odaklanıldığı görülmektedir. Daha çok kadınların refahı ve aile içi şiddet üzerine yapılan nitel çalışmalarda mukayeseli STK analizleri veyahut vaka incelemeleri yapılmıştır (Bener 2009; Sallan-Gül, Özen \& Kahya 2017). Bununla birlikte STK'lar ve gençlerin gönüllülükle ilgili düşünceleri üzerine yapılan çalışmalar da STK ve aile çerçevesinde değerlendirilebilir (Yentürk et al. 2006; Balaban \& İnce 2015). Ayrıca erkeklerin babalık rolleri ve çocuk yetiştirmedeki sorumluluklarına son dönemlerde literatürde değinilmeye başlanmış ve bu konuda özellikle Anne Çocuk Eğitim Vakfı (AÇEV) proje geliştirip raporlar sunmuştur (örneğin AÇEV 2017). Her ne kadar farklı gruplar için birçok çalışma olsa da STK'ların aile üzerindeki etkileri ve ailenin güçlendirilmesi üzerine detaylı bir çalışma yapılmamıştır. STK'lar ve ailelere odaklanan yegâne çalışma, Semra Demirkan'ın 2006 yılındaki "Türk Ailesinin Korunması ve Güçlendirilmesinde Sivil Toplum Kuruluşları ile İşbirliğinin Önemi” başlıklı makalesidir. Bu çalışmada ise Aile ve Sosyal Araştırmalar Genel Müdürlüğü ile aile üzerine odaklanan sivil toplum kuruluşlarının 2005 yılında gerçekleştirdiği toplantının öne çıkan başlıkları verilip genel öneriler sunulmuştur. 


\section{Veri ve Yöntem}

$\mathrm{Bu}$ çalışmada nitel ve nicel araştırma yöntemleri kullanılmıştır. Araştırmanın nicel kısmında aile merkezli çalışan dernek ve vakıfların listesi T.C. İçişleri Bakanlığı ile T.C. Vakıflar Genel Müdürlüğü'nün Şubat ile Nisan 2019 tarihleri arasında internet sayfalarındaki bilgilerden derlenmiş ve kurumların hedef kitleleri çerçevesinde tasnifler yapılmıştır. Çalışmanın ikinci aşamasında ise aile merkezli çalışan 20 sivil toplum kuruluşunun yönetici ve üst düzey temsilcisiyle yarı yapılandırılmış derinlemesine mülakatlar yapılmıştır. Mülakatlarda değişik alanlarda ve farklı siyasi görüşleri temsil eden vakıf ve dernekler seçilmiş; ancak aile odağını kaybetmemek için sadece kadına odaklanan kurumlar, sadece eğitim veren dernekler veya meslek örgütleri araştırma kapsamına dahil edilmemiştir. Yaklaşık 30 ile 120 dakika arasında süren mülakatlar, Kasım 2018 - Nisan 2019 tarihleri arasında çoğunlukla kurum merkezlerinde veya mülakat yapmaya müsait bir mekânda gerçekleştirilmiştir. 


\section{Stk'ların Nicel Tasnifi}

T.C. İçişleri Bakanlığı verilerine göre 2020 yılında Türkiye'de 119.387'si aktif 188.847'si pasif olmak üzere toplam 308.234 dernek bulunmaktadır (T.C. İçişleri Bakanlığı, 2020). İncelenen aktif dernekler içinde 1.865 tanesi aile ve ilgili alanlarda faaliyet göstermektedir. T. C. Vakıflar Genel Müdürlüğü (2019) istatistiklerine göre ise 2017 yılında 4.870 adet aktif yeni vakıf bulunmaktadır. İncelenen vakıflar içinde 2.012 tanesi aile ve ilgili alanlarda faaliyet göstermektedir. Tasnif yapılırken T.C. Vakıflar Genel Müdürlüğü’nün tasnifi dikkate alınarak eklemeler yapılmısstır. Kurumun bu tasnifinde hedef kitlesi bakımından aile yoktur; ancak çocuk ve genç, yaşlı, yoksul, kadın, engelli, belli hastalığı olanlar, çevre, belli bir kurumda çalışanlar veya meslek sahipleri ve diğer vakıflar olmak üzere toplam 9 hedef kitlesinde ayrım yapılmıştır. Vakıfların faaliyet alanları, vakıf isimleri ve varsa web sayfasındaki içeriğe göre yeniden tasnif edilmiştir. Dernekler ise yine dernek isimleri, T.C. İçişleri Bakanlığı'nın web sayfasında hedef kitleleri ve varsa web sitesindeki içeriğe göre tasnif edilmiştir. Tablo 1'de dernek ve vakıfların hedef kitleleri ve faaliyet alanları gösterilmektedir. Buna göre kodlaması yapılan 2.012 vakıftan 79'u aile üzerine odaklanırken, incelenen 1.865 dernekten 191'i aile ile ilgili faaliyetlerde bulunmaktadır. Hedef kitleleri incelendiğinde vakıfların çok büyük bir kısmı genç (1.693) ve çocuklara (1.655) odaklanmaktadır. Kadın (558) ve yaşl1 (495) üzerine faaliyet gösteren vakıflar da mevcuttur. Derneklerde ise yine en yüksek hedef kitlesini gençler oluşturmaktadır. Bunu sırasıyla kadın (528 adet) ve çocuk (448 adet) takip etmektedir.

\begin{tabular}{|l|l|l|l|l|l|l|}
\hline \multicolumn{6}{|l|}{ Tablo1: Hedef Kitlesine Göre Vakıf ve Dernek Sayıları } \\
\hline & Aile & Çocuk & Genç & Yaşlı & Kadın & Toplam \\
\hline Vakıf & 79 & 1.655 & 1.693 & 495 & 558 & 2.012 \\
\hline Dernek & 191 & 448 & 629 & 71 & 528 & 1.865 \\
\hline Toplam & 270 & 2.103 & 2.322 & 566 & 1.086 & 3.877 \\
\hline
\end{tabular}

Not: Vakıf ve dernekler birden fazla alanda faaliyet gösterdiklerinden ayrı alanların toplamı toplam vakıf ve dernek sayısından fazla çıkabilir. 
İller bazında incelendiğinde genel olarak aile odaklı çalışan vakıf ve derneklerin yaklaşı yüzde 25'inin İstanbul'da olduğu görülmektedir (Tablo 2). Bunu sirasiyla Ankara (yüzde 14), İzmir (3.8), İçel (2.6), Bursa (2.3), Adana (yüzde 2.0) ve Antalya (yüzde 2.0) izlemektedir. Bu yedi ildeki vakıflar ve dernekler Türkiye'de aile odaklı çalışan tüm sivil toplum kuruluşlarının yarısından fazlasını oluşturmaktadır. Birçok dernek merkezi de İstanbul'da bulunmakta ve diğer illerde şubeleri veya örgütleri bulunabilmektedir.

\begin{tabular}{|l|l|l|}
\hline \multicolumn{3}{|l|}{ Tablo2: İllere Göre Vakıf ve Dernek Sayıları } \\
\hline & Sayı & $\%$ \\
\hline Adana & 77 & 2,0 \\
\hline Ankara & 543 & 14,0 \\
\hline Antalya & 76 & 2,0 \\
\hline Bursa & 88 & 2,3 \\
\hline İçel & 101 & 2,6 \\
\hline İstanbul & 964 & 24,8 \\
\hline İzmir & 148 & 3,8 \\
\hline Diğer & 1880 & 48,5 \\
\hline Toplam & 3877 & 100,0 \\
\hline & &
\end{tabular}


Tablo 3'te sivil toplum kuruluşlarının internet ve sosyal medya kullanımları verilmiştir. Buna göre 2.012 vakfın yaklaşılk yüzde 38'inde web sayfası, yüzde 33'ünde Facebook hesabı ve yüzde 20,5'inde Twitter hesabı olduğu tespit edilmiştir. Dernekler analiz edildiğinde internet ve sosyal medya kullanımının vakıflara göre çok daha düşük olduğu görülmektedir. Buna göre 1.865 dernekten yüzde 18,1'inin bir web sayfası vardır. Yüzde 32,1'inin bir Facebook hesabı ve sadece yüzde 12,5'inin bir Twitter hesabı bulunmaktadır.

\begin{tabular}{|l|l|l|}
\hline \multirow{2}{*}{ Tablo 3 - 1: İnternet Kullanan Vakıf ve Dernek Sayıları } \\
\hline & \multicolumn{2}{|c|}{ Web Sayfası } \\
\cline { 2 - 3 } & Sayı & $\%$ \\
\hline Vakıf (N: 2.012) & 763 & 37,9 \\
\hline Dernek (N: 1.865) & 338 & 18,1 \\
\hline Toplam (N: 3.877) & 1101 & 28,4 \\
\hline
\end{tabular}

Tablo 3 - 2: İnternet Kullanan Vakıf ve Dernek Sayıları

\begin{tabular}{|l|l|l|}
\hline \multirow{2}{*}{} & \multicolumn{2}{|c|}{ Facebook } \\
\cline { 2 - 3 } & Sayı & $\%$ \\
\hline Vakıf (N: 2.012) & 668 & 33,2 \\
\hline Dernek (N: 1.865) & 598 & 32,1 \\
\hline Toplam (N: 3.877) & 1266 & 32,7 \\
\hline
\end{tabular}

Tablo 3 - 3: İnternet Kullanan Vakıf ve Dernek Sayıları

\begin{tabular}{|l|l|l|}
\hline \multirow{2}{*}{} & \multicolumn{2}{|c|}{ Twitter } \\
\cline { 2 - 3 } & Sayı & $\%$ \\
\hline Vakıf (N: 2.012) & 413 & 20,5 \\
\hline Dernek (N: 1.865$)$ & 234 & 12,5 \\
\hline Toplam (N: 3.877) & 647 & 16,7 \\
\hline
\end{tabular}




\section{MÜLAKAT BULGULARI}

Mülakat bulguları on ana başlık altında toplanabilir. STK'ların odaklandığı konulardan aile kurumunun karşılaştığı tehditlere kadar çok farklı konularda mülakatlardan elde edilen bilgiler bu bölümde sunulmaktadır.

\section{STK'ların Odaklandığg Gruplar}

Farklı STK mensupları ile yapılan görüşmeler sonucunda kuruluşların farklı odak noktalarının olduğu görülmüştür. Görüşülen STK'ların hedef kitlesine göre faaliyetlerinin de değiștiği tespit edilmiştir. Diğer taraftan bazı STK'ların odakları aynı olsa dahi faaliyetleri dikkate alındığında aileye ve onun ihtiyaçlarına yaklaşımlarının farklılaştığı görülmüştür. STK'ların odaklarına göre öne çıkan gruplar aile, kadın-anne, çocuk-genç olarak üç başlıkta incelenebilir.

\section{Aile}

Araştırmaya dâhil olan STK mensuplarının da ifade ettiği gibi bir bütün olarak aile alanında çalışan çok az sayıda dernek ve vakıf bulunmaktadır. Kuruluşlardan bazıları aileyi farklı fertlerden oluşan bir grup olarak ele alırken bazıları ise aileye bütüncül bir bakış açısıyla yaklaşmaktadır. Aile ismiyle faaliyet gösteren STK'lar ise çok değişik alanlarda faaliyetler göstermektedirler. Örneğin, baz1ları sadece kendi aileleri için hizmet veren vakıflarken bazıları ise meslek kuruluşu olarak faaliyette bulunmaktadır. Başka bir ifadeyle isminin içinde aile olan bazı vakıf ve derneklerin gerçekten aile kurumunu ilgilendiren geniş kapsamlı çalışmalar yaptığını söylemek güçtür.

Aile STK'larının bazıları aile danışmanlık merkezleri açmakta veya bu merkezlerin açılması konusunda talepte bulunmaktadır. Muhafazakâr bir STK yöneticisi bunu şu şekilde ifade etmektedir:

“...aile içi iletişimi gerçekten etkili hale getirmek lazım; biz iletişim yani konusmayı beceremiyoruz, belki dinlemeyi beceremiyoruz, belki iletişimsizlik problem doğuruyor aile içerisinde, bununla alakalı bir seyler yapılabilir. Aile danışmanlık merkezlerini biz zaten önermiştik. İnsanlar önlenebilir sorunlar yüzünden boşanıyorlar.” (Kadın, Yönetici) 
$\mathrm{Bu}$ ifadeden de anlaşılacağ üzere aile bireyleri arasında iletişim kurmak çok büyük önem arz etmektedir. Dinlemeyi ve konuşmayı bilmeyen bireyler arasında bir iletişim mümkün olmamaktadır. Bu iletişimsizlik, eşler arasındaki sorunların büyümesini ve hatta boşanmaları beraberinde getirmektedir. Yürütülen aile danışmanlık merkezleri gibi faaliyetler bunun önüne geçmek için tasarlanmaya çalışılmıştır. Bu alanda aile üzerine odaklanan seküler bir STK temsilcisi de benzer bir şekilde aile danışmanlık merkezlerinin önemine vurgu yaparken aileye bütüncül bir bakış getirmiştir.

Aile danışmalık merkezleri hususunda da bir ikilem olduğu yapılan görüşmeler sonucunda ortaya çıkmıştır. Görüşülen STK mensupları arasından bazıları eşlere yönelik olan bu danışmanlıkların eşlerle beraber yapılması gerektiğini, böylece bir bütünlük sağlanacağını savunmaktadır. Bu sistem sağlandığında ise ebeveynlerin öğrendikleri şeyleri kendi aralarında tartışmakla kalmayıp aynı zamanda birbirlerine de yardımcı olmaları hedeflenir. Bu şekilde sorun odaklı eğitimler verilerek fayda en üst seviyeye çıkarılmaya çalışılmaktadır:

“...sadece annenin ya da sadece babann eğitilmesi doğru bir yöntem değil. İkisi birlikte eğitilmeli. Hatta ikisi aym seminerde bir arada oturtulup dinletilmeli, en verimli șeklinin bu olduğunu düşünüyoruz ki tutarlllık olsun." (Kadın, Yönetici)

Araştırma dâhilindeki başka bir STK temsilcisi ise, aile ile dolaylı olarak ilgilenmektedir. Bu anlamda ailenin bozulmasina sebebiyet veren medyaya odaklanmaktadır. Bireyleri bilinçlendirmeye çalışmakla beraber aile fertleri için zararlı görülen içeriklerin kaldırılması konusunda mücadele etmektedir. Yönetim kurulu üyesi yaptıkları faaliyetleri şöyle açıklamaktadır:

"Medyanın aileye yaptığ etkileri incelemek üzere, yani sahadaki etkilerini incelemek, kamuyla ve diğer STK'larla is birliği yaparak bir farkındalı oluşturmak amacıyla çıtı. [Çalısmalarımız]] televizyonla sinırlandırdık, televizyonun çocuklara olan etkisi, ailelere olan etkisi, bir de aile büyüklerine kadar yani yaşhlara etkisine kadar çeşitli seminerler ve eğitim faaliyetleri verdik." (Kadın, Yönetim Kurulu Üyesi)

Anlaşıldığı üzere özellikle televizyon ve onun içeriklerine odaklanılmıştır. Bu anlamda söz konusu STK birçok seminer düzenle- 
yerek aileyi televizyonun zararlı yönleri üzerine bilinçlendirmeyi amaçlamaktadır. STK bu mücadeleyi verirken aile bireylerine hakları konusunda bilgiler verilmiş, ayrıca bazı programların RTÜK tarafindan kaldırılmasında önemli rol oynanmıştır. Bu mücadeleyle aile fertleri ve özellikle de çocuklar için faydalı programların yayınlanması amaçlanmıştır.

Yukarıda zikredilen alanlar dışında diğer odaklarla da (örneğin, dezavantajlı sayılabilecek aileler) ilgilenilmektedir. Bu anlamda madde bağımlılığı ile alakalı mücadele yürüten bazı STK temsilcileri bu alanla ilgili alışılagelmiş bir yöntem olan yardım dağıtma yolunu seçmektense bilinçlenmeye yönelik eğitim seminerleri düzenlemeyi tercih etmektedirler. STK temsilcisinin ifadelerine göre bu eğitimlerle sağlanmak istenen, ailelerin buna karşı bilinçlenmesi ve bu şekilde korunması, içinde bulunduğu bir durumdan kurtulabilmesidir (Kadın, Başkan). Birçok STK'nın yaptı̆̆ı eğitimlerden farklı olarak araştırmaya katılan STK'lardan birinin temsilcisi atölye faaliyetlerine daha çok ağırlık verdiklerini ifade etmiştir. Bu şekilde aynı sorunlarla karşılaşan aileleri bir araya getirerek bir tecrübe paylaşımı oluşturulmaktadır. Tecrübe paylaşımıyla daha gerçekçi sonuçlar alınacağı bu anlamda düşünülmektedir.

\section{Kadın ve Anne}

Birçok STK mensubu odağını kadın olarak dile getirmektedir, bu sebeple de faaliyetlerini kadınlara göre düzenlemektedirler. Bu faaliyetler incelendiğinde çok değişik alanlarda, kadınlara yönelik çalışmalar olduğu görülmektedir. Bazıları ev hanımlarına yönelik çalışmalar yaparken bazıları da kadına yönelik şiddet gibi konularda faaliyetler yürütmektedirler. Birçok dernek ise odaklaşmaya gitmeden çok farklı alanlarda çalışmalarını sürdürmektedir.

Kadın ve anne odaklı faaliyetlerin yoğun bir şekilde yapılmasının önemli sebeplerinden birisi de kadınlara ulaşmanın kolaylığıdır. Birçok STK yetkilisi, erkeklerin gerek ücretli işlerdeki yoğunlukları gerekse kadın ve aile konularına ilgisiz olmaları sebebiyle aile odaklı STK'larda çalışmadıklarından şikâyet etmişlerdir. Bazı muhafazakâr STK mensupları bunu erkeklerin daha çok siyasete meyletmeleriyle ilişkilendirirken STK'ların erkeklerin önceliği olmadığından yakınmışlardır. Muhafazakâr STK mensuplarına göre 
kadınlara ulaşmanın kolay olmasının bir diğer sebebi ise dinî içerikli toplantılardır. Bu STK'lar, düzenledikleri dinî içerikli toplantılarla kadınların ilgisini çekerek ardından başka aile ve anne eğitimi gibi farklı içerikli toplantılara da katılım sağlamaktadırlar.

Görüşülen STK'lar arasında kadınlara odaklanan muhafazakâr STK'ların birçoğunun faaliyetleri arasında ilmihal okumaları ve Kur'an-ı Kerim dersleri bulunmaktadır. Burada kadınlara dinî içerikli dersler verilmekte, bu derslerin seviyesi ise isteğe göre artmaktadır. Bu bağlamda, isteyen kadınlara bu eğitimler meslek seviyesine gelecek şekilde verilirken isteyenlere de gerekli fikhî bilgiler aktarılmaktadır.

Çalışan kadınları destekleyen STK'lar olduğu gibi ev hanımları için kurulmuş STK'lar da mevcuttur. Bu STK'nın amacı ev hanımlarının kendi değerlerini keşfederek bilgi sahibi olmaları ve toplumda daha güçlü bir yer edinmeleridir. Bu konuya odaklanan bir STK temsilcisi şu ifadeleri kullanmaktadır:

“...ev hanımları önemli bir kitle, ev kadınlarının kıymeti bilinmiyor. Ne kendileri bulunduklarn durumun önemini biliyor ne de çevresi onun yaptığ 1 işi takdir ediyor. Bizim hareket noktamız bu oldu. Ev kadınları bilinçlensin istiyoruz, sadece ev işleri konusunda değil toplumsal konularda çözüm üretecek şekilde güçlensinler. Aslında bunları buralardan da alabilirsiniz yola çıkıs noktamız bu." (Kadın, Dernek Üyesi)

Burada vurgulanmak istenen ev kadınlarının problem çözücü yönlerini geliştirmek ve onların kıymetini ailesinin diğer fertlerine karşı kanıtlamak, basit bir iş olarak görülen ev hanımlığının ne kadar kıymetli olduğunu göstermektir. Bu amaç doğrultusunda kuruluş tarafından ev hanımları için seminerler düzenlenmekte ve raporlar hazırlanmaktadır.

Odağına kadınları almış başka bir STK temsilcisi yaptıkları çalışmaları şu şekilde ifade etmektedir; “....ailelerin mutlu olmaları toplumun güçlü olması demek. Onun için de olaya anneden başladık çünkü anne evin çatısıdır, direğidir, her şeyidir bence anne evin...” (Kadın, Başkan). STK yöneticisinin ifadelerinden de anlaşılmaktadır ki, sağlıklı bir toplum için sağlıklı ailelere ihtiyaç olduğu, bunun da yuvanın temel taşlarından biri olan anneye yönelik eğitim 
çalışmaları ile geliştirilebileceğidir. Söz konusu STK kadınlarla başlayarak daha sonra erkeklere, ardından çocuklara ve son olarak da aile büyüklerine benzer eğitim hizmetleri vermektedir. Bu eğitimler sivil toplumun parçadan bütüne giden bir faaliyet cetvelinde aileyi bir bütün olarak ele aldıklarını göstermektedir.

Dezavantajlı olarak adlandırılan kesimlere hitap eden birçok STK da bulunmaktadır. Bu STK'lardan bazıları kadınları odağına almakta ve buna uygun yardım ve eğitim faaliyetleri yürütmektedirler. Burada dezavantajlı olarak adlandırılan sosyo-ekonomik statüleri düşük ailelere yardımlar yapılması hedeflenmektedir. Bu dezavantajlı gruplar özellikle eğitim faaliyetleriyle topluma kazandırılmaya, meslek edindirme kurslarıyla ekonomik olarak güçlendirilmeye çalışılmaktadır. Görüşülen STK'lar arasında bir tanesi özellikle kadın ve genç kızlara meslek edindirme, becerilerini geliştirme ve hayata aktif katılmalarına katkı sağlama adına eğitimler düzenlemektedir. Özel olarak projelerinden birinde kadınları gıda sektörüne kazandırmak ve bundan geçimlerini sağlamayı hedeflemektedirler. Bu proje şu şekilde anlatılmaktadır:

\begin{abstract}
"Projenin genel amacı, sosyo-ekonomik açıdan dezavantajlı durumda olan eğitim ve gelir seviyesi düşük kadınlara gıda/hizmet sektöründe iş bulmalarını kolaylaștırmak adına meslek kursları düzenlemek, bu kadınları ve aile bireylerini psikolojik destek hizmetleri ile güçlendirerek bilinçli ve daha sağlıklı düşünce yapısın kazanmalarına yardımol olmak, sosyal geri kalmışlıkların önüne geçmek ve aile ekonomisine katkılarımı artırmaktır." (Kadın, Yönetim Kurulu Üyesi)
\end{abstract}

Bu ifadede de görülmektedir ki söz konusu kadınlar topluma kazandırılmaya çalışılmakla beraber aynı zamanda refah seviyelerini yükseltmek için de ortam hazırlanmaktadır.

Yardım amacıyla kurulan STK'lardan bazıları ise öğrencilere burs vermektedir. Öğrencilerin eğitimlerini desteklemek amacıyla verilen bu burslar çoğu zaman seminer şartı ile genç kızlara verilmektedir. Burada amaç devamlılığı sağlamak ve bu öğrencilerin sadece kendi alanlarında değil, başka alanlarda da bilgi sahibi olmalarını sağlamaktır. Eğitimli kızlara verilen burslar sayesinde geleceğin annelerinin en iyi şekilde yetiştirilmesi planlanmaktadır. Bir STK temsilcisi bu faaliyetleri şu ifadelerle açıklamıştır: 
"Ve pozitif ayrımcilık yaparak kızlara burs veriyoruz. Onun dışında bu gençleri eğitmek her konuda hedefimiz ve bu gençlerin işte iyi bir anne, bundan sonra da kendi geliștirdiği nesilleri de güzel yetiştirmelerini sağlamak bütün derdimiz. Çünkü biliyorsunuz kadın annedir. Türkiye'nin yarısı kadın yarısı da doğuran kadın ve bu kadınlar yetiștiriyor nesilleri. Nesilleri yetiştiren annelerdir. Hani biz șimdi erkeklere bazı şeylerde kızıyoruz ya hiç kızmayalım. Biz annelere kızalım. Çünkü onları yetiștiren annelerdir. Onun için de bizim daha güzel yetiştirmemiz lazım.” (Kadın, Başkan)

Anlaşılmaktadır ki öğrenim gören genç kadınlara odaklanılmasının sebebi, onların nesli yetiştiren ana grup olarak görülmesidir. Bu bağlamda kızların eğitilmesi uzun vadede çocuklarının da eğitilmesi anlamına gelmekte ve böylece sağlıklı bir aile meydana getirilmesi öngörülmektedir.

\section{Çocuk ve Gençler}

Örneklemdeki STK'lar incelendiğinde azımsanmayacak sayıda STK, çocuk ve gençlere yönelik çalışmalar yapmaktadır. Farklı STK'ların çocuklar ve gençler için yaptıkları incelendiğinde STK mensuplarının mesleki becerilerinin, ilgi alanlarının ve hedeflerinin, dernek ve vakıfların faaliyet türlerini de etkilediği görülmektedir.

Literatürde de görülebileceği gibi Türkiye genç bir nüfusa sahiptir (Aysan 2014). Genç nüfusun insan kaynağını artırmak ve belli değerleri kazandırmak için ülkemizde gençlik politikaları üretilmektedir (Acar 2008). Bu aktarım sağlanmadığında istenmeyen genç kuşakta psikolojik sorunlarla karşılaşılmakta, gençler topluma katkı verememektedirler (Tuncay 2000). Aşağıda da bahsedileceği üzere STK'lar çok farklı faaliyetleriyle gençlerin sosyalleşmelerine de katkı sağlamaktadırlar. Bazı STK'lar çocuk ve gençleri ayrı kategoriler olarak ele alırken bazıları ise ikisiyle de ilgilenmektedir.

Çocuk yoğunluklu çalışan STK'ların çoğunluklu olarak yardım amaç1 faaliyetler yürüttüğg̈ü görülmektedir. Söz konusu STK'lar genel anlamda dezavantajlı çocukların ve ailelerin ihtiyaçlarını gidermeyi ve onları korumayı amaçlamaktadır. Dezavantajlı çocuklara dair yapılan çalışmalara verilebilecek en iyi örnek ise sevgi evleridir. Burada çocuklar için bir aile ortamı oluşturulmaya çalışılmaktadır. Bu çerçevede çalışmalar yapan bir STK temsilcisi bunu şu şekilde açılamıştır: 
"Dezavantajlı çocuklara ev açıyoruz ama o çocukların bir kere eğitim destekleri ile ilgili eğitim ve gelişim merkezlerimiz var. Buralarda yetenek, beceri eğitimleri, akademik başarı eğitimleri ve manevi eğitimler yapllıyor." (Kadın, Koordinatör)

Burada bir aile ortamı oluşturulmasının yanında, yukarıdaki ifadeden de anlaşılacağı üzere eğitimler verilerek bu dezavantajlı sayılan çocuklar, topluma kazandırılmaya çalışılmaktadır. Dezavantajlı sayılabilecek başka bir kesim ise sokak çocukları olarak görülmektedir. Sokaklarda mendil satan, çöp toplayan, dilencilik yapan çocuklar, çoğu zaman kendi gelişimleri için tehlikeli ortamlarda hayatlarını sürdürmektedirler. Hayatlarını idame ettirebilmek adına başka seçenekleri olmayan bu çocuklar eğitimden uzaklaşarak geleceklerini de riske atmaktadırlar. Görüşülen STK'lar arasında özellikle bu konuyla ilgilenen bir STK yetkilisi şunları söylemiştir; "Sokakta çalışan her bir çocuk bağımlılık taşıma konusunda, bunlara bulaşma konusunda risk altında. Bizim çalışmalarımız her zaman önleyici hizmet" (Kadın, Yönetim Kurulu Üyesi). Burada önleyici hizmet olarak bahsedilmekte olan şey çocuklara yardım ederek onları eğitime ve okula yaklaştırmak ve böylece de bu çocukları sokaktan kurtarmaktır. Bu bağlamda aileyi kötü alışkanlıkların zararlarına karşı bilinçlendirmek ve böylece bu alışkanlıkların meydana gelmeden önünün kesilmesi istenmektedir. Aynı zamanda bu çocuklarla ve aileleriyle geziler düzenlemek ve onlara sosyal bir ortam sağlamak da faaliyetler arasında yer almaktadır.

Araştırmada yer alan STK'lar arasında bilhassa yetimlerle ilgilenen, onlara ve ailelerine yardımda bulunan STK'lar göze çarpmaktadır. Gezi programları, nakdî destekler ve anne eğitimleri yetimler için yapılan faaliyetlerden sadece birkaçıdır. Bu konu ile ilgilenen bir kuruluş temsilcisi bunu “...özellikle anneyi güçlendirmeye yönelik olarak eğitim ve danışmanlık hizmetlerimiz söz konusu” (Kadın, Yönetim Kurulu Üyesi) şeklinde dile getirmiştir.

STK'ların çocuklara ve gençlere ulaştırdıkları yardımlar sadece burs ile sınırlı kalmamış; okul imarı, kitap yardımları, hak bildirme, bilinç geliştirme, eğitim ve gezi gibi faaliyetleri de içermiştir. Çocukları ve gençleri maddi boyutta iyileştirmekle kalmamış onları kültürel anlamda da geliştirerek toplumda iyi bir konumda olmaları için önayak olunmuştur. Çocukları korumak ve onlara sahip çıkmak için bazı STK'lar sosyal politikalar üretmek dişında hukuki süreçlere ve düzenlemelere de katkı sağlamışlardır. Bir STK yöneticisi şu ifadeleri kullanmaktadır: 
"Şimdiye kadar sağllk, özellikle çocuk sağlı̆̆ı, çocuk eğitimi, çocuk hukuku alanlarında önemli çalışmalar gerçekleştirdik. Bunun yanında çocuk haklann ile ilgili bir çalışmamız oldu." (Erkek, Yönetici)

Çocukların haklarını koruma çalışmaları yürütmekle beraber aynı zamanda çocukların sağlığı ve eğitimi gibi önemli konularda da çalışmalar yapılmaktadır. Başka bir STK yetkilisi faaliyetlerden birinin de çocuk istismarına karşı insanları bilinçlendirmek ve bu anlamda sadece ailelerle sınırlı kalmayarak çocuklara temas eden kişileri ve öğretmenleri de bilinçlendirmeye çalışmak olduğunu ifade etmiştir. Daha çok sağlık alanında çalışmalar yapan başka bir STK ise mesleki dayanışma ortamı kurarak yaptığı faaliyetlerle o alanda eğitim alan öğrencileri çalışanlarla buluşturarak öğrencilerin mesleki yeterliliklerini artırmaya çalışmaktadır. Yetkili bunu şu şekilde ifade etmektedir:

"Sağllk mesleğinde olan kişilere yönelik olarak bir süreç var. Yani şöyle hem öğrenciler hem de bu mesleği yapan yetişkinler söz konusu. Genç yetişkinler, yetişkinler olarak kategorize ediyoruz biz bunu. Yetişkinlerden burs bağısçısı olarak ve mesleki fayda yönünde faydalanıyoruz. Öğrencileri de filizlenmek üzere bir tohum olarak görüyoruz." (Kadın, Yönetim Kurulu Üyesi)

Bu bağlamda öğrenciler yeşermekte olan bir kaynak olarak görülürken, meslek sahipleri de bir maddi kaynak yani bir yardım kaynağ1 olarak görülmektedir. STK alanında gençlere fotoğrafçılık gibi farklı dallarda eğitimler de verilmektedir. Böylece gençler kendileri gibi benzer ilgilere sahip gençlerle birlikte olmanın yanı sıra ilgi duydukları bir hobiye dair bilgi sahibi olmaktadırlar.

\section{Derneklerin Eğitim ve Seminer Faaliyetleri}

Birçok STK eğitimle ilgili faaliyetler yürütmektedir. Bunlar içinde okul öncesi çocuk eğitimi, annelik eğitimi, babalık eğitimi ve dinî eğitimler öne çıkmaktadır. Genellikle aile fertleri ayrı ayrı eğitilerek desteğe ihtiyacı olan yönleri güçlendirilmeye çalışılmaktadır. Aile eğitimlerini odağına almış bir kuruluşun yöneticisi bu eğitimlerin önemini şu şekilde ifade etmektedir:

"Bir taraftan okul öncesi eğitim programı bir taraftan da baba programı. Daha sonra da anne destek programı, doğrudan annelik becerilerine odak- 
lanan bir program gelişiyor. Çünkü hem kadınların güclenmesi hem de ayn zamanda annelik becerileri açısından bir prospect sokmak, iște bir dengeli beslenmek için farkh gidalar hakkında bilgi sahibi olmak, okula götürmek, bir sürü şey açısından düşünün." (Erkek, Yönetici)

Bu ifadeden de anlaşılacağı üzere bu yapılan faaliyetlerin hepsi birbiriyle alakalı hatta birbirini besleyen çalışmalar olarak görülebilir. Böylece sağlıklı beslenmeden aile içi ilişkilere kadar çok farklı alanlarda aile üyeleri bilgilendirilerek aile güçlendirilmeye çalışılmaktadır. Bununla birlikte aile içi eğitimden ziyade sağlık ve aile planlaması üzerine odaklanmış STK'lar da vardır. Bu faaliyetlerle başta kadınlar olmak üzere aile üyelerinin bilinçlendirilmesi ve sağlıklı bir şekilde üreyebilmeleri hedeflenmektedir. Bir kuruluş yetkilisi faaliyetlerini şu şekilde açıklamaktadır:

"Üremek isteyene ve istemeyene yardımcı olacak şekilde bilgilendirme yapmaya çalışıoruz. Aym zamanda ölümleri azaltmak adına kişinin sağlı̆̆ na, anne-bebek sağglığına ilişkin neler yapılması gerekir, sahada çalışmalar yürütüp farkındalık sağlıyoruz." (Kadın, Eğitmen)

Ailede din eğitimi de eğitim faaliyetleri içinde önemli bir yer tutmaktadır. Yapılan araştırmalar, ailede verilen din eğitiminin çocukların kişilik gelişiminde büyük rol oynadığını ve belirli değerlerin çocukluk yıllarında bireylere aktarıldığını göstermektedir (Aydın 1996). Özellikle muhafazakâr STK'ların aileye danışmanlık ve eğitim verirken dinî değerleri temel aldıkları görülmüsstür. Ailede din eğitimine odaklanmış muhafazakâr bir STK mensubu şu ifadeleri kullanmaktadır:

"Ailede din eğitimi programımızın gayesi ailelere 0-18 yaş grubu çocuklarına din eğitimi verirken zorlandıkları alanda formasyon kazandırmak. Aslında, önce çocukla alakalı bütün gelişim alanlarına ilişkin, ebeveyn tutumlarına ilişkin genel eğitimler veriyoruz. Sonrasında din eğitimi kısmına geçip, çocuklara din, ahlak, Kur'an-ı Kerim eğitimi, dinî gelişimde ev düzeni, en son da ebeveynlerin istifade edebilecekleri yazılı görsel kaynaklar eğitimi veriliyor.” (Kadın, Yönetici)

Verilen ifadeden de anlaşılacağı üzere temel eğitimin yanında dinî eğitim de verilmektedir. Böylece verilen eğitimleri din altyapısıyla güçlendirmek ve bu şekilde ailede bir bağlılık sağlanması öngörülmektedir. Bu eğitmelerde verilen materyallerle de süreklilik 
sağlanması amaçlanmaktadır, böylece eğitim süresi bitse bile bu materyaller sayesinde sıkıntı çekilen konulara geri dönülebilir ve sorun kolayca halledilebilir.

Görüşme yapılan STK'ların faaliyetleri incelendiğinde kadınlar, anneler, erkekler, babalar, gençler ve çocuklar gibi farklı yaş ve cinsiyet grupları ile profesyonel çalışanlar, öğrenciler, bağımlılar, göçmenler gibi özel gruplar da olabilmektedir.

Yapılan eğitim ve seminer içerikleri incelendiğinde annelik-babalık eğitimi, eşlere yönelik rutin eğitimler, aileyi temel alan seminerler, okul öncesi eğitim, okuma-yazma programları, kadın sağlığı eğitimi, yoksul kadınların istihdamı için verilen eğitimler, gençlere yönelik cinsel sağlık eğitimleri, ev hanımları için eğitimler, çocuklarda taciz ve istismarı anlama ve koruma üzerine seminerler, değerler eğitimi, dinî eğitimler, üniversite öğrencilerine yönelik özel seminerler, bağımlılık çalışmaları, iletişim üzerine atölyeler gibi çok farklı konularda seminer ve eğitim faaliyetleri yürütülmektedir.

Görüşme gerçekleştirilen STK'lar genellikle kadınlar üzerine odaklandıklarından, faaliyetleri de daha çok kadın ve annelerin sorunlarına yönelik olmaktadır. Bununla birlikte ailenin sadece kadının sorumluluğunda olmadığı, babanın da aile ve çocuğa dair konularda sorumluluk alması gerektiği mülakatlarda sıklıkla vurgulanmıştır. Bununla ilgili bir kuruluş yetkilisi şu ifadeleri kullanmıştır:

“...sadece annenin ya da sadece babanın eğitilmesi doğru bir yöntem değil. İkisi birlikte eğitilmeli. Hatta ikisi aym seminerde bir arada oturtulup dinletilmeli. En verimli şeklinin bu olduğunu düşünüyoruz ki tutarlllk olsun. Karşıllklı konuşabilsinler, tartışabilsinler, hani bir sonuç çıkabilsin. Biz STK'lar ya anneleri eğitiyoruz ya çocuklarn eğitiyoruz ama babalarla ilgili çok az şey var..." (Kadın, Başkan)

Eğitim faaliyetlerinde öne çıan başka bir husus ise kuruluşların genelde daha çok belli bir temaya odaklanıp diğer alanları ihmal edebilmesidir. Bu çerçevede psikoloji ve din eğitimini örnek veren bir STK çalışanı bu alanlardan birinin ön planda olup diğerinin ihmal edilmesinin doğru olmadığına, eğitim noktasında dengenin oldukça önemli olduğuna dikkat çekmiştir: 
"Görebildiğimiz kadarıyla ailede din eğitimi eksik bırakıllyor ya da sadece buraya yoğunlaşarak işin psikolojik boyutu ihmal ediliyor. Türkiye’de ana baba okulu yok değil ancak daha çok belli bir kesimin yürüttüğüi, içinde din eğitiminin olmadığ çalışmalard. Dini esas alan kuruluşlarda da eğitimin gelișim boyutu ihmal ediliyordu. Aileye temel dinî bilgi vermekten ziyade aileye formasyon kazandırmak esas olmah." (Kadın, Yönetici)

Gerek Türkiye'de gerekse dünya genelinde tek bir aile tipinden söz edilemeyeceği gibi tek bir aile tipine odaklanarak eğitim faaliyeti yapmak da mümkün değildir. Bazı dernek çalışanları farklı aile tiplerini dikkate alarak her ailenin kendine özgü değerleri, doğruları olduğunu; eğitimde de bu farklılıkların dikkate alınması gerektiğini şu ifadelerle dile getirmiştir:

"Farkh aile grupların değerlendirip o şekilde eğitim verilmeli. Günümüzde artık homojen bir aile tipi yok, farkh aile tiplerini göz önünde bulundurarak hareket etmeleri gerekir diğer STK'ların da. Değişen, dönüssen dünyaya ilişkin aileleri bilinçlendirme, bir kullanım kılavuzluğu/rehberlik oluşturma yönüyle desteklemek gerekiyor." (Kadın, Yönetici)

Birçok STK aynî veya nakdî yardımlar da yaptıklarından bazı aileler STK'lardan eğitim faaliyetlerinin yanı sıra maddi destekte bulunmalarını da beklemektedirler. Vakıf, yoksul bir aile ile ilgilendiğinde maddi yardımda $\mathrm{m} ı$ bulunacak yoksa hayat süreçleri ile ilgili eğitim mi verecek, bu konuda netlik olmadığında ailelerden vakfın götürdüğü hizmetin dışında talepleri olabilmektedir. Bu konuda bir STK yetkilisi şu ifadelerle durumu özetlemektedir:

“...dernekler genellikle yoksulluğu gidermeye çalışıyor. Balık tutmayı öğretmiyor. Doğumla ilgili bilgi vermeye gittiğimde "ne yardım yapacaksın, bebek bezi yok mu?" sorularıyla karşılaşabiliyorum. Hâlbuki benim ona verdiğim bilgi daha kahıcl; ancak bunun farkında değil. Dernekler maddi yardım yaptıklarında algı bu yönde gelişiyor ve eğitim faaliyetleri geride kahıyor." (Kadın, Eğitmen)

Aile içi sağlıklı iletişim gerek eşler gerekse ebeveyn ve çocuk arasındaki ilişkilerin sağlıklı kurulması ve duygusal bağın korunması için oldukça önemlidir. Bununla birlikte aile içinde sağlıklı iletişim kurulamayınca yeni sorunlar ortaya çıkmakta, var olan sorunların çözümü ise zorlaşmaktadır. Aile içi iletişim 
üzerine eğitimler veren bazı kuruluşlar olmakla birlikte bir katılımcı STK'ların bu yönde daha çok eğitim düzenlemesi gerektiğini ifade etmiştir.

"Aile içi iletişim konusunda eğitim düzenlenmesi gerektiğini düşünüyorum. Aile içinde dilsiz iletişim çok önemli, olumlu kullanamıyoruz maalesef. Genellikle şiddetli bir iletişim dilimiz var, iğneleyici lafları araya sıkıştırmaktan oldukça hoşlanıyoruz." (Kadın, Eğitmen)

Vakıf ve derneklerin eğitimlerde önem verdikleri bir diğer nokta ise çocuk istismarıdır. Çocukları cinsel istismardan koruma noktasında kişilerin bilinçlendirilmesini önemseyen birçok STK sadece çocuğa değil aileye ve profesyonel çalışanlara da eğitim verilmesi gerektiğini vurgulamaktadır. Cinsel istismar durumlarında çocuk kendini sözel olarak ifade edemese de hâl ve hareketleriyle dışarıya sinyal vermektedir. Bunu erkenden anlama ve müdahale etme noktasında sadece ailenin değil profesyonel çalışanların da oldukça bilinçli olması gerekmektedir. Bu çerçevede bir katılımcı şunları ifade etmiştir:

"Ailede böyle bir şey varsa çocuğun hemen koruma altına alınması gerektiğini düsünüyoruz ve gerekli tedbirler konusunda bilinçlendiriyoruz herkesi. Bu şekilde devam ediyor. Bu eğitim sadece öğretmenlere verilmiyor. $O$ okulda çalışanlara da veriliyor. Kamu çalışanlarına, şirket çalışanlarına da veriliyor. Aile diye ayırmıyoruz. Sevgi evlerinde de veriliyor. Yani amacımız şu: Eğer çocuk böyle bir istismara maruz kalıyorsa aile içinde ya da dışında bunu ifade edebilir ya da edemese bile sinyalini verebilir. Siz bu sinyalleri algilayın. Yani aslında sinyalleri göstermek için biraz. Eğitimlerde bunlar anlatiyoruz. Ve sonrasinda neler yapmak lazım, dikkat etmesi gereken şeyler ne vs. bunlara bakiyoruz." (Kadın, Yönetim Kurulu Üyesi)

STK'larla yapılan görüşmeler sonucu ortaya çıkan bir diğer husus ise kuruluşların aileye yaklaşımı ile ilgili algı farklılığıdır. Buna göre bazı STK'lar aileyi eğitmenin yolunun kadını eğitmekten geçtiğini savunurken bazı STK'lar buna karşı çıkmakta ve ailenin tüm üyelerinin birbirinden ayrılamayacağını, bir bütün olarak ele alınması gerektiğini söylemektedir. Bu konu ile ilgili bir katılımcının görüşleri şu şekildedir:

"Yani aileyi parçalayarak yaklaşan yaklaşım bana uygun gelmiyor. İște kadın için yola çıkanlar, çocuk için yola çıkanlar, işte şimdi bir de erkekler için 
başladı. Erkeklerin haklarmı korumaya çalışanlar da var. Yani bu parça parça ele alınacak bir şey değil. Aslında bir bütün.” (Kadın, Yönetici)

\section{Aileye Yönelik Tehditler}

1970'li yıllarda Türk haneleri televizyon ile tanıştı. Bu yeni ve cazibesi yüksek kitle iletişim aracı kısa süre içerisinde Türk toplumu açısından önemli bir kültür inşa edici hale geldi. Etkili bir toplumsal iletişim aracı olarak televizyonun Türk ailesini nasıl ve ne yönde etkilediğiyle ilgili veri elde edilmek istendiğinde, maalesef yeterli kaynak bulunamamaktadır. Televizyonun evlerimize girmesiyle ivme kazanan kitle iletişimi, internetle tanışmamızla birlikte bir iletişim patlaması haline gelmiştir. Bu patlamanın orta ve uzun vadede ülkenin kültürüne, aile yapısına, inanç ve değerlerine yapacağı etkilerin kestirilmesi kolay değildir. Ancak medyanın hangi formu tarafindan olursa olsun, topluma sunulan değerlerin zaman içinde kitlelerce özümsendiğini söylemek mümkündür. Bu noktada, Türk ailesinin gereksinimleri ve değerlerine uygun olmayan herhangi bir kitle iletişim ürününün çıktısının gelecekte sağlıksız ilişkiler ile örülmüş bir toplum ortaya çıkaracağını tahmin etmek zor değildir.

Aile kurumunun devamı, bireylerin sağlıklı gelişimi; gelenek, görenek ve inançların muhafazası için medya eleştirisi yapmak; medyayı çok dikkatli bir şekilde okumak, anlamak ve denetlemek gerekmektedir. Medya tarafindan sunulan kültürel ürünler alıcı tarafından tüketilirken yeni bir yaşam biçimi oluşturmakta ve kimi "doğruları" empoze etmektedir. Aile ile ilgili çalışmalar yapan STK'lar ile görüşmeler neticesinde, yukarıda zikredilen kaygıların farklı STK yöneticileri tarafindan paylaşıldığı; bu problemlerin toplumsal yapıda görünür hale geldiği söylenebilir. Görüşülen STK yöneticilerinden büyük bir kısmı aile yapısı için en büyük tehditler arasında medyayı ifade etmiştir. Bu yanıtları gerekçelendirdiklerinde, problemin özellikle de sosyal medya ile ilişkili olduğu görülmektedir. Bu anlamda, bireysel çerçevede aileler tarafindan medyanın eleştirel bir okumasının gerçekleştirilmesi; kamu ve STK'lar tarafından da medyanın zararlı etkilerine karşı koruyucu ve önleyici tedbirler alınması gerektiği vurgulanmıştır.

Medyanın aileye yaptığı etkileri incelemek, kamu ve diğer STK'larla iş birliği yaparak bir farkındalık oluşturmak amacıyla kurulan bir 
derneğin yetkilisi, kuruluş gerekçelerini açıklarken medya konusunda "bir bilinçsizlik, bir şuursuzluk," olduğuna dikkat çekmiştir (Kadın, Yönetim Kurulu Üyesi). Televizyonun toplumu kötüye götüren etkilerine odaklandıklarını belirten yetkili, sosyal medya konusunda ise oldukça yetersiz kaldıklarıyla ilgili öz eleştiride bulunmuştur:

\begin{abstract}
"Ama bununla beraber Türkiye şeyle tamş̧t, sosyal medya ve biz de onun aslında ne olduğunu, herkes gibi, biz de bilmiyorduk. Halen de çok bildiğimiz, bununla ilgili çok ciddi araștırmalar yapıldığın söyleyemeyiz. Fakat artık iş bizim biraz daha spesifikleșmeye başladı medya üzerindeki etkiler. Dediğim gibi televizyonla sınılandırdık, televizyonun çocuklara olan etkisi, ailelere olan etkisi, bir de aile büyüklerine kadar, yani yaşllara etkisine kadar çeșitli seminerler ve eğitim faaliyetleri verdik. Özellikle, yani halktan insanlarla, hakikaten halktan, normalde belki bir akademisyen anlattığinda onu anlamayacak insanlara, teyzelere, amcalara evlilik programlarınn olumsuz etkisini, onlarn nasıl bir hayal dünyasına sürüklediğini, nasıl bir fason olduğunu, balon olduğunu anlattı." (Kadın, Yönetim Kurulu Üyesi)
\end{abstract}

Türk izleyicisinin reality show tarzında, özellikle gündüz kuşağında yayınlanan programlarla tanışmasıyla birlikte, ki bu programların önemli bir kısmını evlilik programları oluşturmaktaydı, toplumsal değerler noktasında ciddi manada bir yozlaşma yaşandığı vurgulanmaktadır. Benzer şekilde; hanımlara, gençlere ve çocuklara yönelik eğitim, kültür ve dayanışma faaliyetleri gösteren bir başka dernek yetkilisi de sosyal medyanın aile üzerindeki yıkıcı etkisine dikkat çekmektedir:

"Sosyal medya toplumun dinamiklerini kökten yıkıyor, bir anda şoklandık mı kullanmasın bilemedik, ifrat tefrit toplumuyuz zaten hemen değerlendiremiyoruz. Sosyal medya bizi çok zorluyor; iletişimsizlik ve hedefsizlik, ekonomi, bunlarm hepsi bir araya geldikten sonra kendini sosyal medyayla patlattığım düşünüyorum ailenin ve hanımın. Her şeyin önüne geçti, değerlerimizin önüne geçti, manevi dinamiklerimizin de içinin boşaldiğııı... En büyük problemin, problem mi sonuç mu onu bilemiyorum, ama sosyal medya... Yani sosyal medya insanlarm hayal güçlerini kirlettiğini ve aileyi parçaladığın düşünüyorum ana sebebi bu." (Kadın, Yönetim Kurulu Üyesi)

Odak noktası olarak çocukları alan bir başka derneğin yetkilisi ise sosyal medyanın aileleri kültürel anlamda olumsuz biçimde dönüştürdüğünü; Batı kültürüyle bir melezleşmeye neden olduğunu 
ifade etmektedir. Türk aile kültürünün, özellikle de çocuk yetiştirme noktasında, uğradığı dönüşümü sosyal medyanın yarattığ1 “dijital diktatörlük” ile gerekçelendirmektedir:

"Ailede kültürel yoğunluğun giderek azaldığın düşünenlerdenim. Ve bir yönüyle de aile sosyal medyanın kuşatması altında, dolayısıyla ailede çok farkh kültürlerin yansımasıyla oluşan bir melezleşme hali var. Türkiye toplumu ağırlıklı olarak bu melezleşmenin içinde davramıs ve tutumlar bakımından. 0 bakımdan o kültürel yoğunluk azaldıkça aile değerlerimizin geleneğimizle olan ilişkisinin koptuğunu düşünüyorum. Çünkü çocuğa ait ninni söyleyen anneler ninni söylemeden büyütüyor bebeklerini. Tekerleme, kendi tekerleme söylemeden geçiriyor çocukluğunu. Geleneksel oyun oynayamadan tamamen mekâna kapah, mekâna bağlı, kapahı bir toplum hayatı içinde değil mi? Kapalı mekânlara hapsedilmiş çocukluk söz konusu. Ve neyi tüketiyor? Medyayı kullanıyor işte... Dolayısıyla en büyük ve en önemli tehlikelerden biri de bu geleneksel kültür ve medeniyet dairesinin geleneksel kültürle ilgili alamının daralmış olmasıdır. Bu medya kuşatmasıdır, dijital diktatörlüktür; bu bütün dünya için en büyük tehlikedir. Bütün insanlık için bu uyarıcı görevini tüm insanların da yapması gerekir." (Erkek, Yönetici)

Yukarıda zikredilen sosyal medyanın kültürel yozlaşmaya neden olduğu fikri birçok farklı mülakatta dile getirilmiştir. Örneğin, ailenin devamlılığını öncelik olarak alan bir başka derneğin yetkilisi de teknoloji temelli bir bireyselleşme ve değer kaybına işaret etmektedir:

“...Siz çocuğu bir değerle buyurtuyorsunuz, bir yere getiriyorsunuz mesela ben şimdi 44 yasındayım. Bakıyorum çocuğu bir yere getirmişsiniz, belli değerleri ailede öğretmisssiniz, ama o algl var ya hani önceden derdik ya hep arkadaşlarmdan etkileniyor, okula gitti arkadaşlar söyle. Şimdi sosyal medya, diziler, televizyonu geçtik, internet üzerinden izledikleri diziler var ya... İste o sosyal medyadaki paylaşımlar, su sunu yapmış bu bunu yapmış, her şeyiyle... En çok teknolojiden etkileniyoruz. Bireyselleşme de teknoloji ile oluyor, hani değerlerin değişimi de teknoloji ile oluyor. Hani en büyük kaybı dersem hani bence değer kaybı. Hani ailesi, anne babası bir arkadaş gibi olacaksa arkadaşa küstüğü gibi anne babaya küsecekse, değil mi? Küfredecekse yani başka şeyler yapacaksa, aile kalmamıştır bence, gidiyor demektir. İnşallah o kadar olmaz da ama bu gidişatta öyle yani." (Kadın, Yönetici)

Aileler için ahlaki ve manevi eğitimi önceleyen bir başka derneğin yetkilisi de medyanın yaptığı etkiyi "kültür erozyonu” olarak nite- 
lendirmekte ve bu bağlamda çocukların maruz kaldığı tehlikelere işaret etmektedir:

"En önemli olan ailenin dışından gelen kültür... Ailenin kapalı bir tarafinin olması gerektiğini düşünüyorum ki kendi iç dinamiğini kurabilsin, bir değer sistemi oluşturabilsin ama biz şu an evlerimizin kapısını açmış durumdayız mahrem alan yok. Bu tabii medya yoluyla gerçekleşiyor. Aile etkisini yitiriyor. Mahremiyeti olan, sinırlar olan aile yapısından söz etmek mümkün değil. Çocuğun emanet edildiği yerler, kişiler, anne evdeyken bile çocuğunu emanet ettiği ekran... Ailenin içerisinde bir yaptırım vardır. Bazı değerleri, kuralları vardır; aile fertleri de çok dışına çıkmak istemez. Olması gereken de budur. Aile budur yani. Aile sosyal hayata hazırlayan ilk kurumdur ama aile bu geçişi yapmadan çocuk maruz kaliyor birçok şeye, çocuk hazırlanmadan topluma gönderilmiş oluyor. Çocuk donanıml olmayan bir varlkk; bunu ben şeye benzetiyorum, bağışıklık kazanmamış bir bünyenin hastalıklı ortama gönderilmesine. Aile o bağışılılğı kazandırma sürecinde etkilerini kaybetmedi ama etkili olduğu süreyi çok daralttı diyebilirim." (Kadın, Yönetici)

Araştırma sürecinde ortaya çıkan bir diğer bulgu ise aileye yönelik tehditler söz konusu olduğunda, muhafazakâr STK'ların LGBT mevzusunu da sosyal medya ile ilişkilendirerek açıklamalarıdır:

"Bir LGBT olayı var mesela. Buna eğilmek istiyoruz artık çünkü göz ardı edilemez bir noktaya vardı. Dolayısıyla biz buna birazcık eğilmek istiyoruz ama tabii bu çok büyük bir mesele. Bununla alakah sosyal medyada çocuklarn olumsuz etkileyen, bir STK vardı hatta geçenlerde tepki gösterdiler ve şikâyet ettiler. Yani bu ciddi aileyi tehdit eden bir noktaya varabilir. Celebrity dediğimiz kişilerin de çocuklara bu anlamda gözükmesi bunu tabii tetikledi. Ailenin bence en büyük tehdidi şu anda o. Zaten herhalde amaçlanan da aileyi tamamen ortadan kaldırmak." (Kadın, Uzman)

Sosyal medya her an kitlelere ulaşabilme özelliği sayesinde ürettiği "fenomen" kişileri kısa bir sürede hayatlarımıza dahil etmektedir. Geçmişte etkileri bu denli belirgin olmayan olaylar veya topluluklar bu yeni mecra sayesinde hızla görünürlük kazanmakta, izleyicilerde farklılığa karşı kayıtsızlaşma oluşturmaktadır. Mülakatlarda bazı katılımcılar LGBT ve benzeri grupların sosyal medyayı aktif kullanarak kamusal anlamda etki alanlarını genişletme imkânı bulduklarını ifade etmişlerdir. Görüşme yapılan birçok STK 
temsilcisi bu konuyu gündeme getirmekte ve aileye tehdit olarak görmektedir. Ancak bazı STK temsilcileri ise farklı aile tiplerinin ortaya çıktığını belirterek, bu değişik aileler için de faaliyetler üretmek gerektiğini söylemişlerdir. Seküler bir kurum yöneticisi Türkiye'nin aileye dair en önemli konularından biri olarak aile içi demokrasiyi sayarken şunları ifade etmiştir:

"...aile içi demokrasiyi güçlendiren eşler arası, illa da her zaman karı koca da bir aileyi illa da heteroseksüel bir kadınla heteroseksüel erkeğin birliği olarak da düşünmüyorum, düşünmemeliyiz, düşünemeyiz; gerçeklik öyle değil zaten farklı farkh formlar." (Erkek, Yönetici)

Daha önce bahsedildiği üzere, LGBT konusu mülakat kişileri tarafından çoğunlukla sosyal medyanın getirdiği olumsuz etki ile birlikte ele alınmaktadır. Bu noktada yapılan bir diğer değerlendirme de LGBT mevzusunun aynı zamanda bir "kolay yoldan para kazanma" aracı olarak görüldüğü; bilişsel, zihinsel yahut ruhsal bir farklılığın ürünü olmaktan ziyade, tamamen maddi kaygılarla "köpürtüldüğüdür":

"Geçen gazeteci arkadaşlardan biri paylaşmış, yabancı ülkelerden birinde, 11 yaşlarnnda erkek çocuk sürekli makyaj yaparken video koyuyor. Onların ikonlarl var, neydi o, Kerimcan... 2007'de biz [...] derneği olarak bir çalışma yapmıştık, eşcinselliğe neden bu kadar özeniliyor diye. Orada mesela sormuştum ben devrin gazetecilerine işte demişti ki Can Atakl, diğer kesimde önemli bir gazeteci, aslında çok bunların arkasında büyük yönlendirmeler yok. Bülent Ersoy, Zeki Müren bugün çok paralar kazamyorsa, Taksim'e çıkan o çocuklar veya eşcinsellik yapan çocuklar bunun için çıkıorlar. Şimdi de Kerimcan bile belki eşcinsel değil, bilmiyoruz yani. Bu bir tercih, liberal bir yönelim değil, resmen kapitalizmin bir ayağı. İnanılmaz paralar kazandiğı defalarca yazıldı Kerimcan'ın. Bunların temel nedeni gerçekten kapitalizm. Yine o paraya teslim olma meselesi. Çok vahşi bir süreçteyiz yani. Sosyal medya üzerinden çok kolay para kazanilyyor. Paranın nasıl mutlu ettiği gösteriliyor. Değerler karmaşası yaşıyoruz dünya olarak." (Kadın, Yönetim Kurulu Üyesi)

Medyanın ve özellikle de sosyal medyanın, gözlemlenen olumsuz etkilerini sıralamanın yanı sıra, araştırma bulguları arasında bu sorunların çözümüne yönelik bazı öneriler de getirilmektedir. Katılımcı bunlar içinde denetim kadar otokontrolün önemine vurgu yapmıştır. 
“...Demek ki diyorum bir STK'cl olarak, devletin daha çok müdahale etmesi lazım. Daha çok filtrelerin otomatik koyulması lazım yani. Okulların erişimlerle ilgili bir sinır koyması lazım. Bizim şimdi akıllı telefonunu aldık diyelim 13 yaşındakinin elinden. Benimkini alyyor bu sefer, babasmmnkini alyyor, ablasinmnkini alyyor her boşlukta. Çözümsüz demiyorum hani ben yasaklara inanıyorum ama yeterli değil. İçerik üreticileri, mesela son bir Youtuber tutuklandı, çok iyi yaptılar yani içerik üreticileri, STK'lar, bunu kesinlikle raporlamanız istiyorum, içerik üreticilerinin kendine gelmesi için ve onların takip edilmesi için daha çok çaba sarf etmeli kamuya. Kamunun da savcıların, yargıçların, bakanlı̆̆ın bir mekanizma oluşturması lazım." (Kadın, Yönetim Kurulu Üyesi)

Yukarıda da ifade edildiği gibi var olan değerlerin; kültürel ve dinî hassasiyetlerin korunabilmesi için en yaygin öneriler RTÜK ve benzeri kurumlar aracıllğıyla medyanın denetlenmesi ve gerektiğinde cezalandırılması olurken, öne çıkan alternatif öneri ise Türk aile yapısıyla uyumlu yerli içerik üretimidir. Bir katılımcı daha çok kontrollü yerli içerik üretmek gerektiğini ifade etmiştir (Kadın, Yönetim Kurulu Üyesi).

\section{STK ve Devlet İlişkisi}

STK ve devlet ilişkisini ele almadan önce sivil ve devlet kavramlarının üzerinde durulması gerekmektedir. Bu iki kavram her ne kadar birbirinin karşıt anlamlısı gibi gözükse de aralarında organik bir bağ bulunmaktadır. Sivil, belli bir forma sahip olmayan anlamına gelmektedir. Devlet ise belli bir sistem içinde örgütlenmiş insan topluğunun varlık kazanmış halidir. Bu kısa tanımlardan hareketle Türk Dil Kurumu, toplumdaki çeşitli sorunları bağımsız olarak ele alıp kamuoyunu bilgilendirme ve aydınlatma görevi yapan, öneriler sunan her türlü birliğin sivil toplum örgütü olduğunu ifade etmektedir. Söz konusu tanım düzleminde düşünüldüğünde kendisiyle mülakat yapılan her bir STK temsilcisi, farklı kavramları referans alarak bir tanım yapmaktadır. Örneğin, referans kavram hedeflenen amaç olarak nitelendiğinde bir katılımcı "sivil toplum kuruluşu, kendi amacı doğrultusunda o amacı gerçekleştirmek için bir araya gelmiş olan, hakikaten devletle ilişkisi olmayan insanların yöneldiği ödevler" şeklinde tanımlamakta ve devleti STK'nın dışında tutmaktadır (Erkek, Başkan). Öte yandan mülakat yapılan derneklerin birçoğu STK'ların devletle iş birliği içinde olması gerektiğini söylemişlerdir. Nitekim “devlet STK'ya önderlik eder, öncülük eder” ifadesiyle bir kuruluş başkanı devlet ve STK’la- 
rin topluma hizmet konusunda birlikte ve ayrilmaz hareket etmesi gerektiğini vurgulamaktadır. Devletle bir bağ kurulup kurulmamasının ötesinde sadece gönüllülük esasına göre de yapılan STK tanımları da vardır. Bir katılımcı bunları şu şekilde açıklamıştır:

"Hepimizin de bildiği gibi "gönüllülüğe dayalı çalıșma" girişimleri yani STK'lar, toplumların gelişmelerine önemli katkllarda bulunmaktadırlar. Bu tür girişimlerle toplumsal zitlaşmalar ve kutuplaşmalar azalmakta; sosyal moralite yükselmektedir. Ayrıca STK'lar, modern dönemin kâr gütmeyen kuruluşları olarak insanlar arasındaki yardımlaşmayı artırmıs;; sivil girişimlerin toplum hayatındaki geliştirmeci rollerini çoğaltmıştır." (Kadın, Yönetim Kurulu Üyesi)

Yukarıdaki ifadelerden de açıkça anlaşılacağı üzere STK'ların gönüllülük esasına göre varlıklarını sürdürmesi gerektiğini düşünenler vardır. Buna karşın diğer bir STK temsilcisi ise gönüllülüğün kurumsallaşma önünde bir engel oluşturduğunu düşünmektedir. Aynı zamanda bu kurumsallaşmanın devlet ile ilişkisinin faaliyetler, yönlendirme ya da yukarıda ifade edilen önderlik boyutunda değil fonlama ile gerçekleştirilmesi gerektiği aynı kişi tarafından vurgulanmaktadır.

"Bir taraftan Osmanlı'yı da düşünüyorum vakıflar kurulduğunda orayı profesyonel bir sisteme oturtmaya gayret etmişler. Belki devamlılığl olsun. Gönüllüler üzerinden yürüyen sistemin devamlılı̆̆ olmuyor. Devletle ilişkisinde de eğer devlet çok karışmyorsa ve fonluyorsa o da bir anlamda sürdürülebilirliğini sağlamış oluyor... Evet, gönüllülük kurumsallaşmamalı ama bir yandan da bu tarz şeyleri gönüllülerle yürütemiyorsunuz." (Kadın, Başkan Yardımcisi)

Yukarıda yapılan tanımlarla da bağlantılı olarak denilebilir ki; çağdaş anlamıyla sivil toplum, birey özgürlüklerinin ve temel haklarının korunduğu gönüllülü̈k temelinde örgütlenmenin asil olduğu, toplumun devletin önüne geçerek devlet politikalarını denetleyip yönlendirebildiği yurttaşlık bilincine dayanan bir gelişmişliği ifade etmektedir. (Ylldırım 2003: 226)

Yukarıda yapılan mülakatlardan açıkça anlaşıldığı üzere temsilciler daima devletle organik bir bağ kurulmasını önemsemekte ve bunun ise kurumsallaşmayla birlikte gönüllülük esasıyla devam ettirilme- 
si gerektiğini vurgulamaktadırlar. Söz konusu bağın, aile ile ilgili devlet politikalarının STK'lar ile danışılarak yürütülmesi gerektiği farklı özelliklerdeki STK'lar tarafından sıklıkla dile getirilmiştir.

\begin{abstract}
"Kesinlikle devlet bu yönde politika yapmah ve buna katılmalı. İs birliği şart. Mesela biz şimdi çocukları cinsel istismardan koruma eğitimi veriyoruz. Bunu devlet eliyle verebilsek çok daha iyi olur. Ya da çocuklarla ilgili istismarn önleme ile ilgili ceza hukukundan kaynaklı davaları azaltmakla ilgili pek çok projemiz var. Bunlarn devlet eliyle, Millî Eğitim Bakanlı̆̆ eliyle, işte müfredata konulan dersler vs. yapılması gerekiyor zaten." (Kadın, Yönetim Kurulu Üyesi)
\end{abstract}

Aynı şekilde odağı din eğitimi olan başka bir STK temsilcisi ise devletin, ailenin ihtiyaçlarına yönelik politikalar üretmesi gerektiğini ifade edip şunları söylemiştir:

"Kesinlikle üretmeli, ihtiyaç var. Bunun araștırmaya dayalı olması gerekiyor, bilimsel olmast gerekiyor. Yurt genelinde araștırma yaparsa, STK'lara da destek verirse iyi olacağın düşünüyorum. Bu anlamda bakanlıkla iș birliği içindeyiz, orada da aym çalışmalar yapılmasın talep ettik. Birlikte hareket edilmesi çok önemli. Aileyle ilgili çalıșmalar oldukça olumlu, kitaplarn mevcut, faydalandık. Din eğitimi ile ilgili henüz yok fakat. Bu konuyla ilgili de politikalar üretmeli diye düšünüyorum." (Kadın, Yönetici) Bütün STK temsilcileri, devletin aile ile ilgili politikalar üretmesinin çeşitli sebep ve örneklerle gerekli olduğunu ifade etmektedir. Nitekim bir STK yetkilisi bunun yöntemini de belirleyerek şunlarn ifade etmektedir: "Devlet üretiyor aile ile ilgili politikalar ama felsefesini yanhs yerden alyyor o politikalarm. Yani ben hani gördüğüm kadarıyla, alana girdiğimizden beri bakanlıkla ilgili temaslarımızda hep görüyorum. Batı ülkeleri arașttrilıyor. Oralardan birtakım uygulamalar geliyor ya da işte Avrupa Birliği'ne katılmamız için bazı kriterler geliyor, bazı yasalar ona göre düzenleniyor. Fakat faydalı mı sonuç ortada değil yani. Bir felsefe bunalımı olduğunu düşünüyorum. Bizden olmayan bir politikayla olmuyor yani." (Kadın, Dernek Koordinatörü) Kendisiyle mülakat yapılan kişinin de ifade ettiği gibi devlet, Osmanlı İmparatorluğu'ndan aile ile ilgili hatır sayılır sayıda politikalar üretmektedir. Ancak bu düzenlemelerin Türk toplumun özelliklerini yansittığıyla ilgili birçok STK temsilcisinde ciddi soru işaretleri vardır. Kamuoyunda siklıkla tartışlan ve 2011 yllında imzalanan İstanbul Sözleşmesi de bunlardan birisidir. Bazı STK temsilcileri devletin aile ile ilgili en kötü uygulamasının İstanbul Sözleşmesi olduğunu ifade etmektedirler. Özellikle kadına karşı şiddeti engellemek için imzalanan bu sözleșme sonucunda bazı STK temsilcile- 
rine göre aile yapısı, örf ve adetler dikkate alınmadan kanuni düzenlemeler gerçekleştirilmiştir. Bu durumu bir STK temsilcisi şu şekilde ifade etmektedir:"En kötü uygulama. Şu boşanmayı kadından yana kılan kanunlarla ilgili çok ciddi sıkıntılar olduğunu düşünüyorum. Evet beyamını esas alınmasl. Gerçekten, yani kadıncı bu yaklaşımın adamlarda nelere yol açtığım da kadın cinayetlerinin artışıla görüyoruz yani. Yani yasakçı zihniyetle, cezacı zihniyetle değil bunlar, böyle çözülmemeli yani... Ben hani okuyorum imkân buldukça ama hak verdim yani. Okuduklarımda gördüğüm şey bu. Mesela nafakann ömür boyu olması, bir kadına bir adamın ömür boyu nafaka vermesi, evlense kadn gayrı resmi evleniyor ki nafakam eksilmesin. Bunlar haksızlı yani. Kadını koruyoruz derken erkeği ezen bir politikaya dönüștü bu yani. Dolayısıyla da kendini anlatamayan erkek șiddete yöneldi." (Kadın, Dernek Koordinatörü) Bu bağlamda değerlendirildiğinde kendi geçmişinden beslenen, aym zamanda şu anki aile yapısım ortaya koyan çalışmalar sonucunda politikalar ve nihayetinde mevzuat düzenlemeleri gerçekleştirilmesi gerektiği sıklıkla vurgulanmıștır. Bazı katılımcılar ise devletin mahrem alana ve bireylerin aile yaşantılarna müdahale etmemesi gerektiğini söylemiștir. Bir katılımcı "...siyasi aparatın bir uzantısısınız, bu çok ciddi aile politikasına zarar veriyor. Bütünlüklü bir politika geliştirememenin en önemli nedenlerinden birisi bu" (Erkek, Yönetici).

Bir başka STK yetkilisi ise devletin aile ile ilgili politikalarını ve eksiklerini şu şekilde değerlendirmektedir:

"Üretmeli ve güzel üretiyorlar. Hani şu an gündemi de takip ediyorum. Nafaka olayının son durumunu bilmiyorum ama hakikaten bence bir adam eșten ayrlldıtan sonra ömür boyu para ödemesine karşıım. Bunun dışında Aile ve Sosyal Politikalar Bakanlığı iyi çalışıyor ama bakanlık sık sık değişiyor. Sik sık değiștiği için sistem de değişiyor. Sistem de kişiye göre olduğu için sıkıntılar doğuyor. Bir de ister istemez tekelleșme oluyor yani. Biz STK'ların da bu anlamda bir problemleri var.” (Kadın, Yönetim Kurulu Üyesi)

Bir STK temsilcisi aileyi korumaya dair politikaların üretilmesi gerektiğini şu şekilde ifade etmektedir:

"Evet. Politika ve kanunlar aileyi koruyucu ve kollayıcı çerçevede düzenlenmeli. Aileyi tehdit eden toplumsal cinsiyet eşitliği gibi içeriği muğlak ve yanlıs mecralara çekilebilecek politikalara izin verilmemeli. Aile kurumunu destekleyici sosyal koruma mekanizmalarn oluşturulmal. Toplumun tüm kesimlerini kapsayıcı stratejiler üretilmeli ve aileyi korumaya yönelik stra- 
tejiler uygulanırken hem politikalarm hem de ilgili tüm taraflarm etkin koordinasyonuna önem verilmeli.” (Kadın, Yönetim Kurulu Üyesi)

Politika üretilmesini gerekli gören bir başka STK temsilcisi ise çocuklar ve medya ile ilgili tedbir alınmasının zorunluluğuna dem vurmaktadir:

"Tabii üretmeli mesela biraz evvel bahsettiğim okullardaki olay, devlet yapacak, medyaya bir şekilde devletin ulaşması lazım. Yani bunlar tamam, STK'lara çok rol düşüyor, hepimiz elimizden geldiği kadar uğraşmalıyız ama aile politikası Türkiye'nin politikası, geleceğimizi ortaya koyan bir olay." (Kadın, Başkan)

Ancak mülakat yapılan STK'lar içinde diğerlerinin aksine devletin aileyle ilgili politika üretmemesi gerektiğini söyleyen bir katılımcı da olmuştur:

"Bence özel olarak karıșmamall, diğer kollardan desteklerse sağllk eğitim politikalarına ilave ederse aile bakanlığına ihtiyaç kalmaz. Kadına yönelik şiddete dair bir șey yapılmuyorsa bakanliğa da ihtiyaç yok. Eğitim oldukça önemli, sosyal ve vatandaşlık bilgileri eğitime dâhil edilse bu bilgilerin ailedeki eğitimi destekleyeceğine inanıyorum. Demem o ki, sadece adının olmasıymış gibi var olması gereksiz. Gerçekten o anlamda politika üretebiliyorsa aile bakanlığı olsun." (Kadın, Eğitmen)

Devletin ürettiği söz konusu politikalarla aileye bir müdahalede bulunup bulunmamasını ise mülakat yapılan STK'lar farklı bakıs açılarıyla ele almaktadırlar. Nitekim bunlardan biri devletin herhangi bir aşamada bir şekilde zaten aile ile irtibatlı olduğunu şu şekilde ifade etmektedir:

"Aile bizim mahremimiz ama bugün devletin zaten ailenin içine girdiğini görüyoruz. Bir sorun olduğu zaman, şiddet vakası olduğu zaman, sağllk sorunu olduğu zaman ya da işler yolunda gitmediği zaman ailenin kapıs$m$ çaldığ yer zaten devlet. Bu problemlere devlet cevap veriyorsa, bu problemlerin olmaması için de devlet politika üretmek zorunda. Devlet zaten buna müdahale etmediği zaman kendi is yükünü arttrriyor. Daha fazla problemde kapısı çalınacaktır. Aile eğitim programlarının o anlamdaki kapsayıcilğ̆ bunu karşıllyor. Problem olmadan ya da problem varsa da kendi problemini çözebilen konsept olușturması. Zaten güçlü aile dediğimiz 
aile, problemi olmayan aile değil ki; problemini çözebilen, bu mekanizmaya ulaşabilen, bu iradeyi gösterebilen aileleri olușturmak istiyoruz. Ben dolayısiyla ailenin bilgiye ulaşmasında, ailenin hizmete ulaşmasında devletin rolünün kolaylaștırıcı olması gerektiğini düsünnüyorum. Zaten toplumu oluşturan yapılar aileler genellikle. Aileleri güçlendirirse devlet ve millet de güçlenecektir." (Kadın, Başkan Yardımcısı)

Diğer bir bakış açısı ise kural olarak devletin bu alana karışmamas1 gerektiğini ancak istisnai durumlarda bu müdahalenin zorunlu olduğunu ifade etmektedir.

"Kesinlikle her konuda üretmeli. Bana göre devletin karışamayacağl, yani devletin sımılar bakımından düşünürsek, bireysel özgürlüklere kamuya açık olmadiğı sürece tabii ki devletin asla karışma yetkisi yok. Fakat bir çocuğu ve aciz gruplarn, yani engelli ve yaşhlarn direkt hedef alyyorsa, mesela ylllarca evlilik programlarına çok ciddi zihinsel engelleri olan insanlar çıkarllıp toplum güldürüldü yani onlara. En son artık Tayyip Bey el atana kadar kimse bir șey yapmadı yani. Kaldırın dedi, kaldırdılar. Dolayısıyla onlarn hedef alan, onlarn kahraman yapan içeriklerin hepsine müdahale etme hakkı var. Onları taciz eden, satan, üzerlerinden para kazanan, o zayıf grupla ilgili, çocuklar da bunlarm içinde, her türlü politika üretmeli; el koyma ve dönüştürme yetkisi olmah." (Erkek, Başkan)

STK temsilcileri aile adı altında bir bakanlığın bulunmasını da değerlendirmektedirler. Çıkan sonuçlar neticesinde bu isimde bir bakanlığın bulunması birçok STK tarafından olumlu karşılanırken bir STK temsilcisinin değerlendirmesi şu şekildedir:

“...Aile Bakanlı̆gı'nın dağınık ve kafasının karışık olduğunu düsünü̈yoruz. Bakanlığın yapısının değiş̧ip çalışmayla birleşmesi kesinlikle anlamsız oldu. Zaten Aile Bakanliğı hantal bir bakanlıktı. Hantal, bürokratik. Hantal olarak kurulmuş. Aile Bakanlğ̆ aileyle ya da halkla çok da bütünleşmiş, ihtiyaçların karşılayabilmiş bir bakanlık değil. Biz bir şekilde zaten bakanlarla görüşüyoruz. Bizim ilişkilerimiz var ama ilişkiler üzerinden yürümemesi gerektiğini düşünüyoruz. İcracı bir bakanlık olarak şekillenebildiğini ben görmüyorum. Aile Bakanliğı bizi kuruluşuyla mutlu eden ama onun dışında bakanlı̆ııız da var hissiyatı olușturmayan bir bakanlık." (Kadın, Başkan Yardımcısı)

Özellikle muhafazakâr STK'ların devlet ile ilişkisi her ne kadar 1980'lerde bir karşı duruş şeklinde kendisini gösterse de aile STK'la- 
rı bağlamında yapılan mülakatlardan da anlaşılacağı üzere STK'lar devletin karşısında kendilerini konumlandırmamaktadırlar. Her ne kadar STK'ların devlet ile hiçbir ilişkisinin olmaması gerektiği görüşünü benimseyen STK temsilcileri olsa da toplumsal sorunları aşabilmek için her bir derneğin devlet ile sistemli ve dengeli bir ilişkisinin olması gerekmektedir. Nitekim sivil toplum örgütlerinin devletle ortak çalışmalar yapmaları, ortak projeler gerçekleştirmeleri kaçınılmazdır. Devletin modern toplumlarda toplumsal yaşamın her yanına yayılmış olduğu gerçeğini göz önünde bulundurduğumuzda bu ilişkinin kaçınılmaz olduğu anlaşılır. Devlet, bazı ülkelerde sivil toplum kuruluşları için önemli bir finansman kaynağını oluşturmaktadır. Mesela birçok Avrupa ülkesinde devlet birçok projeyi sivil toplum kuruluşları aracılığıyla gerçekleştirmektedir. Kamu kurumları projeler için finansman sağlamakta, sivil toplum kuruluşları da bu projeleri gerçekleştirmektedir. Yapılan mülakatlar neticesinden Türkiye'de aynı şekilde hibe, bağış gibi yollarla STK'lara fon sağlandığı görülmektedir.

\section{STK'larda Kadın}

Kadının içinde yer aldığı kuruluşlar otoriteyi ve kuralları çok kullanmamaktadırlar. Hiyerarşik bir yapıdan daha ziyade düz bir yapıya sahip olan sivil toplum kuruluşları, gönüllülük esasında çalışan üyeler arasında karşılıklı bağlantılara dayanma eğilimindedirler (Son \& Lin 2006, 333). Kadınların STK'lara katılımının gönüllülük esaslı olması gerektiğini beyan eden bir kadın derneğinin çalışanının naklettikleri de bu görüşü destekler mahiyettedir:

“...Dolayısıyla burada bir sivil toplum kuruluşunda gönüllü faaliyet göstermenin bilincini belki de vermesi ve bu konuda teşvik edici bir atmosferin olusturulması gerekiyor toplum içerisinde. Belki müfredata sokulmalı gönüllülük. 0 gönüllülük bilincini biraz vermek gerekiyor çünkü. Profesyonel hayata giriyorsunuz ve bir STK'da çalışmak çok çok zor oluyor. Ya da insanlar şöyle bir arayışa giriyor, bu hayatta bir şeyler yapmam lazım, artık çok boş hissediyorum kendimi deyip ondan sonra STK'ya sarllıyorlar." (Kadın, Uzman)

Kadın derneklerinin oluşum dinamikleri birbirlerinden farklılık göstermektedir. Hepsinin uzlaştıkları nokta kadın ve kadın haklarına dair çalışmalar yapmak olsa dahi faaliyetler noktasında ayrıştıkları gözlemlenmiştir. Bu derneklerden biri de kadınların bir araya gelip bir kadın derneği kurmalarını şu ifadelerle anlatmıştır: 
"Farklı meslek gruplarından kadınlar özellikle yardım çalışmaları odağında bir araya gelmişler. Hatta onlar referansların anlatırken kırk komşuyu araștırmak ihtiyacı var mi, herhangi bir maddi sıkıntısı var mi diye yola çımışlar. Zamanla da diğer sivil toplum örgütleri kurulmus. 1990'lara gelindiğinde hem bunların sayısı artmış hem ürettikleri hizmetler çoğalmıs, farklılaşmaya başlamıs. O dönemde Dr. Gülsen Ataseven'in özellikle çok önemli bir rolü olduğunu görüyoruz. Her birimiz farklı işler yapsak da bir araya gelelim, sohbet edelim, hiçbir şey yapmıyorsak neler yaptığımızı anlatalım ve bağımızı koparmayalım gibi bir önerisi olmuş.” (Kadın, Başkan Yardımcısı)

STK çalışmalarında kadınların görevlerinin sınırlandırıldığı ve cinsiyet ayrımının bazı alanlarda gözle görülür bir hal aldığından da bahsedilmiştir:

"Onun dışında kadına dair meseleleri kadının bakış açısından çözme gibi bir durum da söz konusu oluyor fakat karar alma mekanizmalarının içerisinde çok kadın yok. Dolayısıyla o noktalara ulaşabilmek anlamında bazen sıkıntılar yaşanabiliyor. Bu da politika anlamında zorlandığımız bir nokta oluyor. Onun dışında zaten kadının karşılaşmış olduğu birçok zorluk var bu alanda, hepsini yaşıyorsunuz." (Kadın, Uzman)

Kadın çalışmalarında ve STK'larda ise daha çok kadınların bilfiil görev aldıkları, erkeklerin ise özellikle aile ile ilgili sivil toplum faaliyetlerine pek katılmadıkları ifade edilmiştir:

"Erkeklerimiz biraz kalifiye olsaydı bu durumda olmazdık. Su anda hanımlar ve kızlarımız çok nitelikli, çok donanımlı. Erkeklerimiz maalesef. İnsallah dua niyetine geçer kızlarımızı geçsin diyeyim, hanımları geçsin. Ekonomik sebepleri bahane ettiklerini düşünüyoruz, sadece ekonomik sebep diyorlar baska bir sebep demiyorlar ama bence çok zor geliyor onlara. Maalesef erkek çalışması çok yürümüyor ama biz gene iyi direndik." (Kadın, Yönetim Kurulu Üyesi)

Kadın derneklerine erkekler bazı durumlarda temkinli yaklaşabilmekte, bu derneklerin faaliyetlerinin eşlerini olumsuz etkilemesinden endişe duymaktadırlar. Bundan ötürü bazı kadınların dernek faaliyetlerine katılımları kocaları tarafindan zaman zaman olumlu karşılanmamaktadır. Görüşmelerde de buna dair şu bilgiler verilmiştir: 
“...bazılarının eşleri [sorun] yapıyordu. Dernek çalışmasına gelince sanki hanımları feminist olacak gibi. Öyle birkaç tepkiyle de karşılaștık. Hâlbuki biz aile bağlarım güçlendirme, saygı, sevgi diye şey yapıyoruz ama bazı eşlerin endişeleri var." (Kadın, Üye)

Bir başka örnekte ise kadınların derneklerde aldıkları eğitimlerin olumlu yansımalarının kocaları tarafından da paylaşıldığı ve zamanla eşlerinin eğitimlere katılmalarını destekledikleri ifade edilmiştir:

“... bazı eşler düşünürler ki hani hanımlar öğrendikçe ukala olurlar, bilmiş olurlar, gitmesinler [eğitime], gelmesinler. Ancak bize dönüșümleri aksine hiçbir zaman böyle olmadr. Devam etmesini istediler. [Kadınlar] kendilerini daha rahatlamıs, kendilerini daha iyi ifade edebilen, ne istediğini bilen hanımlara dönüștü. Hani buna yüzde 100 bir başarı diyemeyiz tabi. Bunu kimse garantileyemez ama istatistik yaparsak yüz kişiden elli kişide biz bunu başarmışı diyebiliriz ve bunu çok büyük bir başarı olarak görüyoruz açıkçası." (Kadın, Yönetim Kurulu Üyesi)

Son yıllarda sıklıkla gündeme gelen kadına karşı şiddetle ilgili yorumlar da yapılmıştır. Dindar bir STK temsilcisi hem devlet hem de toplum nazarında bu konuda kat edilen yol hususunda şunları dile getirmiştir:

"Kadına şiddetle ilgili çok iyi yol alındı. Şimdi bunu medyada söylesek diğer kesim diyecek ki o zaman neden bu kadar çok kadın cinayeti var? 0 başka bir denklem. Keşke daha iyi olsa ama yani bir bilinç oluştu. Bunun [kadına şiddetin] çok kötü, çok çirkin bir şey olduğu [bilinci oluştu.]" (Kadın, Yönetim Kurulu Üyesi)

Son yıllarda kadın ve aile ile ilgili uygulamaların olumlu sonuçları da çalışmaya katılan birçok dernek yöneticisi tarafından ifade edilmiştir. Özellikle 2011 yılında kurulan Aile ve Sosyal Politikalar Bakanlığı aracılığıyla aileye dair birçok uygulama kurumsallaşmış, artan ve çeşitlenen sosyal politikalar sayesinde farklı gruplara ulaşılabilmiştir. Yönetim kurulu üyesi bir kadın katılımcı bu çerçevede kadınların kazanımlarını ve bunun aileye olumlu etkilerini aşağıdaki gibi dile getirmiştir:

“Tabii Bakanliğın projeleri ya da Aile Bakanlığı'nın projeleri devlet nezdinde önemli ve gün geçtikçe geliștiriyorlar. Kadın desteklemeleri, özellikle 
çocuk paralarn olsun, izin süreleri olsun; bunların çok değerli olduğunu düşünüyorum. Ve çalışma hayatında da bunu çok iyi gözlemleyebiliyorum. İnsanlar rahatlıkla çocuk yapmayı düşünüyorlar. Verilen süreler dolayısıyla. Aile bütünlüğü önemli bence." (Kadın, Yönetim Kurulu Üyesi)

Derneklerin yalnızca kadın eğitimiyle ilgilendiği ifade edilmiştir. Ancak aile yalnızca kadının eğitilmesi ile kurulacak veya düzenlenecek bir kurum değildir. Bu konuda erkeklerin eksikliklerini tamamlamak gerekir. Buna ilişkin olarak:

\begin{abstract}
"Seri eğitimlerle anne yetiştirmeye çalışıyorlar ama hiç baba yok. Yani genelde kadin faaliyetleri bunlar. Yani STK'lar da genelde kadınlardan oluşuyor. Aileyle ilgili istifade edenler de hep kadinlar. Yani erkeklerle ilgili sorunun farkına varıp, bu sorun bizim en büyük yaramızdır deyip inisiyatif alıı bir güç yok gördüğüm kadarıla. Hele ki iște dediğim gibi 400'e yakın dernekten bahsediyoruz." (Kadın, Koordinatör)
\end{abstract}

Eğitim ve kültür alanında birçok program gerçekleştiren bu kuruluşlar, Naples'ın (1998) belirttiği gibi birer sosyal değişim ajansı gibi çalışmaktadırlar. Kadın üzerine faaliyet gösteren STK'lara baktığımızda genellikle kadınların bilgi ve becerilerini artırmaya yönelik faaliyetler yaptıkları ve onları psikolojik olarak hayata hazırlamak için eğitimler verdikleri görülmektedir.

"Projenin genel amacı, sosyo-ekonomik açıdan dezavantajlı durumda olan, eğitim ve gelir seviyesi düşük kadınlara gıda/hizmet sektöründe iş bulmalarım kolaylaștırmak adına meslek kursları düzenlemek; bu kadınları ve aile bireylerini psikolojik destek hizmetleri ile güçlendirerek bilinçli ve daha sağlıkı düşünce yapısı kazanmalarına yardımcı olmak, sosyal geri kalmışlıkların önüne geçmek ve aile ekonomisine katkılarım artırmaktır." (Kadın, Yönetim Kurulu Üyesi)

Kadınlara yönelik programların düzenlenmesinde ve bu tür programlara öncelik verilmesinde kadınların talepleri ve STK'ların belirli konularda farkındalık oluşturmak istemeleri öne çıkmaktadır. Muhafazakâr bir STK yöneticisi tarafindan bu durum şu şekilde ifade edilmiştir:

"Aileye gençlik üzerinden ulaşabileceğimizi düşündüğümüz için kadın çaıışmalarımız devam ediyor. Kadının farkındalığın artırmak adına yaptı- 
ğımız çalışmalarımız var, onları kendi arasında kategorize ettik. Sadece Kur'an ögrrenmek isteyen, ilmihal bilgisi almak isteyen hamımlar var. Kurulduğumuz günden beri onlar bilfil devam ediyor, bu noktada vazgeçme olmadı. Bir de kendini geliștirmek isteyen her mânâda hanımlarımız var, onlarla ilgileniyoruz." (Kadın, Yönetim Kurulu Üyesi)

Her ne kadar kadınların farkındalığını artırmak, özellikle anneler için eğitim programları düzenlemek çalışmaya katılan hemen hemen tüm STK'ların önceliği gibi gözükse de yapılan çalışmaların genellikle toplumsal cinsiyet eşitsizliğini azaltmak veya feminist amaçları gerçekleştirmek için yapılmadığı söylenebilir. Bir kısım muhafazakâr STK yöneticilerinin feminizm ile aralarına mesafe koydukları görülmüsstür. Feminizm ile bağdaşan ve yalnızca kadın haklarını ön planda tutup aileyi değersizleştiren uygulamalar da eleştirilmiştir:

\begin{abstract}
"Şimdi burada ben özellikle şunun üzerinde durulmasın istiyorum. Aile deyince hep kadın üzerinden gidiliyor. Kadınlarda maalesef feminist duygular hep ön plana çıkıyor. Yani bir feminizm çalışması gibi geliyor bana. Öyle olmamah yani sağlkhı bir kadın algısı. Kendini küçük gören, zayıf gören, karşısındaki cinsle savaş haline dönüssen kadın değil paylaşımcı. Şöyle bir kural var, ben hep onu da söylerim. Eğer bir kral olmak istiyorsa kişi, eşini kral olarak görmek istiyorsa hanım, o eșe o krallk rütbesini vermeli davramıslarıyla. Aym șekilde hanımlar için de söz konusu. Benim hanım fevkalade olsun, mükemmel olsun diyorsa o bey de o hanıma aynı tavrı gösterecek. Hiç kimse aşağılda bir adamın eşi olmak istemez herhalde değil mi? Herkes çok fazlasını istiyor ama kendine bakmıyor. Fazlasını istiyor ama fazlasım isterken onu yükseltecek davramıșta bulunmuyor, öyle yükseltilmez." (Kadın, Yönetim Kurulu Üyesi)
\end{abstract}

Kadın ile ilgili çalışmalarda muhafazakâr ve seküler kesimin ideolojik ayrışmaları kadar önyargıların da kadına ve aileye dair iş birlikleri geliştirip ortak fikir üretmek için engeller oluşturduğunu muhafazakâr bir dernek temsilcisi şu şekilde ifade etmiştir:

"Özellikle de [kadın çalışmalarında] fikir üreten bir dernek işi yapmak isterken çok çabuk damgalanabileceğiniz, hemen yaftalanabileceğiniz ve birazcı da insanların sizin konuştuklarınıa mesafeli durduğunu hissettiğiniz bir alan oluyor. Bu seküler grup için de böyle fakat kendimize yakın gördüğümüz kişilerden de olabiliyor. Bizi daha farkh görüyorlar söylemler açısından. Biz aslında mesela eşitlik demiyoruz, adalet diyoruz. Yani fitratı 
yok sayan bir bakış açımız yok. Bunu kendi camiamızdaki dernekler [de] kadınla alakah yapılan çalışmaları direkt kafa[ların]da o şekilde kodlamışlar. Siz kadına dair ne söylerseniz söyleyin hemen kafa oraya gidiyor. Ama hani farkh bir bakış açısı getirelim bu meseleye, beraber olalım dediğiniz zaman da birazcık geri planda kallyorlar. Seküler camiadan da nasıl efendim olur, adalet denir mi, olmaz böyle șey gibi șeylerle karşllaşıyoruz. Sadece... [bizim] değil, birçok kadın derneğinin karşılaşmış olduğu birtakım böyle fikirsel anlamda zorluklar oluyor." (Kadın, Uzman)

\section{Aile ve Kadın}

Aileye odaklanan STK'ların en önemli faaliyet alanlarını anneler ve kadınlar oluşturmaktadır. Görüşülen bazı STK'lar ise kadın, anne ve aile ayrımı yapmadan farklı konularda kadınla alakalı çalışmalar yürütmektedirler. Çalışmaya katılan STK'ların yönetici ve mensuplarının büyük bir kısmının kadın olduğu da dikkate alındığında kadın ve annelerin ihtiyaçlarının STK faaliyetlerinin odağına oturması oldukça doğaldır.

Özellikle annelik rolüyle öne çıkan kadın imajı, eğitimli, kültürlü, kendini ailesine adamış, gelecek nesilleri yetiştirmesi umulan, başka bir ifadeyle tüm bu zorlu işlerin üstesinden gelmesi beklenen bir kahramandır. Bu imajı ve ideal tipi farklı görüşlerden gelen birçok STK temsilcisi kadın vurgulamıştır:

“... Ailelerin mutlu olmaları toplumun güçlü olması demek. Onun için de olaya anneden başladık çünkü anne evin çatısıdır, direğidir, her șeyidir bence. Ama șu anda bizim ülkemizde annelerin yeteri kadar sağlam temellerde yetiştirilmediği ya da annelerin biraz daha zayıf ve güçsüz olduğunu fark ettik. Onun için de kadın diye bir sempozyum düzenledik." (Kadın, Yönetim Kurulu Üyesi)

Kadına dair bu beklentiler, onu ailenin de başat aktörü konumuna getirmektedir. Bir STK temsilcisi Türk toplumunda ailenin en güçlü yönü olarak, Türk kadınının karakteristik özellikleri olduğunu aşağıdaki ifadelerde sunmuştur:

"Türk kadın, en özverili kadın tipolojisinden bir tanesidir. Biz de analizleri okuduk, araştırmalar yaptık ama Türk kadını kadar aileye bakış açısı değişik olan çok az insan var, topluluk var. Özverili olması zaten atasözümüzde de yok mu, yuvayı dişi kuş yapar diye. Tamamen kadının üzerinden yürü- 
yor. Zaten kadının dinamiklerini vurduğunuz zaman Türk toplumunda aile kalmıyor. Yıkım kadından başlıyor ashnda." (Kadın, Yönetim Kurulu Üyesi)

Sağlıklı nesillerin yetişmesi, sağlıklı ailelerin ve dolayısıyla sağlıklı anne ve babaların vazifesidir. Ancak geleneksel tutumlar dolayısıyla bu vazife genellikle annelik vasfı olan kadının omuzlarına yüklenmiştir. Dindar bir STK temsilcisi kadın, kadının ailedeki rolüne ve önemine dair şunları ifade etmiştir:

“... biliyorsunuz kadın annedir. Türkiye'nin yarısı kadın [onun] yarısı da doğuran kadın ve bu kadınlar yetiştiriyor nesilleri. Nesilleri yetiștiren anneler. Hani biz şimdi erkeklere bazı șeylerde kızıyoruz ya hiç kızmayalım. Biz annelere kızalım. Çünkü onlarn yetiștiren annelerdir. Onun için de bizim de daha güzel yetiștirmemiz lazım." (Kadın, Yönetim Kurulu Üyesi)

Ancak annenin aile kurumu üzerinde tartış1lmaz bir etkisinin olması kadının tek başına aile kurumunu ayakta tutabilmesi için yeterli değildir. Babanın da bu çerçevede eşine destek olması şarttır. Annenin önemini vurgulayan bir önceki görüşten farklı olarak başka bir katılımcı şu ifadeleri kullanmıştır:

"Biz hep hanımlar üzerinden gidiyoruz o yetmiyor. Gerçi ben hep olaya şöyle diyorum, evin kadın çok önemli, anne çok önemli, annenin eğitimi çok önemli, anne ilk öğretmen ama tek başlarına zayıf kahı." (Kadın, Yönetim Kurulu Üyesi)

İçinde bulunduğu topluluğun imkânları ve imkânsızlıkları, kadının hayatını ve firsatlarını etkilemektedir. Dolayısıyla kadının sosyal hayatının önemli bir parçası olan aile bireylerini de kadının statüsünü ve imkânlarını anlayabilmek için çalışmalara dâhil etmek gerekir. Örneğin, engelli bir çocuğu olan annenin çalışma ihtimali kocası tarafindan çalışması desteklenen veya kreşe erişim imkânları olan bir kadına göre çok daha düşüktür. Kadınlar kavramı üzerine odaklanmış bir derneğin temsilcisi; her ne kadar bu tür çalışmalar yapılıyor olsa da bu kavramı tek başına incelemenin doğru olmadığını, kadını kendi sosyal ortamında ve aile ile birlikte ele almak gerektiğini şu sözlerle ifade etmektedir:

"Kadını tek başına ele aldiğımız zaman sahada çok etkin bir şekilde politikaların ortaya çıkamadığını gördük. Kadını tek başına ele aldığınız zaman sadece kadın güçlendiriyorsunuz, onun sorunlarına yönelik çözümler bulu- 
yorsunuz ama bu kadının yaşadiğı sorun bir şekilde aileyle de ilintili. Yani bunun içerisine siz çocuğu da katmazsamı, işte babayı da katmazsanız bu sefer mesela iş-yaşam dengesinde karşılaştığını, çözüm üretmek istediğiniz sorunlara etkin ve kalıcı çözümler üretemiyorsunuz. Dolayısıyla bir şekilde aileyi de dâhil etmek gerekiyor. Yani çocuğu ilgilendiren bir problem mutlaka kadın da ilgilendiriyor. Kadın olduğu kadar babayı da ilgilendirmesi gerekiyor. Hatta ailedeki büyükleri de dâhil edebiliriz." (Kadın, Uzman)

Aileyi ve toplumu esas alarak kadına ve ihtiyaçlarına yaklaşmak gerektiğini, sadece kadına odaklanmanın sorun oluşturabileceğini başka bir muhafazakâr STK mensubu şu şekilde ifade etmiştir:

"Aile ve kadım ayırmıyoruz. Çünkü kadın platformu gibi düşünmedik. Kadın kuruluşlarının oluşturduğu platform. Bunun içinde afetle ilgili çalışan da var. Din̂̀ eğitim alanında faaliyet gösteren de var. Yardım faaliyeti yapan da var. Çocuk alanında çalışan da var. Genç alanında çalışan da var. Şimdi seküler kesimde kadın çalıșması dediğiniz zaman kadın hakları ifade edilir. Kesin net bir tanımdır. Bizim alanda ise, bizim baktı̆̆ımız yerdense kadın çalışmaları, ya da kadınların çalışmalar diye düzelteyim, toplumun her kesimine ulaşacak bir șekilde yapılmaya, gerçekleștirilmeye çalışılır." (Kadın, Yönetim Kurulu Üyesi)

Yukarıdaki ifadelere paralel olarak yalnızca kadının, çocuğun veya erkeğin haklarını korumaya yönelik tutumların aile yapısına zarar verebildiği de özellikle muhafazakâr katılımcılar tarafindan vurgulanmıștır. Kadını aileden soyutlamamak gerektiği de ifade edilen hususlar arasındadır.

"Yani aileyi parçalayarak yaklaşan yaklaşım bana uygun gelmiyor. İște kadın için yola çıkanlar, çocuk için yola çıkanlar, işte şimdi bir de erkekler için başladı. Erkeklerin haklarmı korumaya çalışanlar da var. Yani bu parça parça ele alınacak bir şey değil. Aslında bir bütün... İnsan olarak yaklaşmak lazım temelde. Tabii aileyi güçlü kılacak dinamiklerde biraz daha Batı'dan gelen olgularla ele alınyor. 0 da sıkıntı, bize o elbise uymuyor. Dolayısiyla da yani çıkarılan yasalar genelde aksülamel yapıyor. Yani iște boşanmalarda, şurada burada gördüğümüz, kadın cinayetlerinde gördüğümüz şey bu gibi geliyor bana. Yani bize uymayan çözümler ürettiğimizde problem var, bu dernekler aslinda o bize uyan elbiseyi tarif edebilmeli. Orada eksiklik olduğunu düşünüyorum yani...” (Kadın, Koordinatör)

Kadın odaklı çalışmaların ve kadın derneklerinin sayıca fazla olması aileyi konu edinen bir STK temsilcisi tarafından eleştirilmiş- 
tir. Kadın hakları üzerine yapılan çalışmaların ve sadece kadın üzerine bu gibi konulara odaklanmanın aileye zarar verdiğini düşünmektedir:

"STK olarak bakıldığında sadece aile odaklı kim var? Yani çok kadın odaklı gidiyorlar sanki. Aile sadece kadın haklarn gibi algilanyyor. Hâlbuki bizim ailede güçlendirmek istediğimiz şey kadın haklar değildir, yani ya da kadının yüceltilmesi değildir." (Kadın, Yönetim Kurulu Üyesi)

Diğer bir görüşe göre ise aile, bazı yönleriyle de kadının güçlenmesine mâni olabilmektedir. Ailenin bütünlügüünü korumak adına göze alınan birçok şey kadının modern anlamdaki özgürlüğüne zarar verebilmektedir. Şimdiye kadar müreffeh bir toplumun yapı taşı olan ailenin, klasik ifadesiyle insanların huzurlu yaşayabilecekleri bir "sığınak" olduğu düşünülürse, 21. yüzyılda ailenin bir zorunluluk olup olmadığı da tartışma konusu olacaktır. Aile, kadına kaliteli bir yaşam imkânı sunmadığı takdirde aile kurmanın mânâsının ne olacağını düşünmeye davet eden muhafazakâr bir STK temsilcisinin şu sözleri düşündürücüdür:

"Feminist kadınlar için aile belki birinci derecede önemli değil. Biz biraz aileyi fazla önemsiyoruz belki... Daha doğrusu çok fazla anlam yüklüyoruz üzerine. Bütün bunlarm her birinin ayrı birer sorun olduğunu düşünüyorum. Aile önemli, önemli olduğu [konusunda] hemfikiriz. Herkes bunu söylüyor ama hangi aile? Nasll bir aile, ne yaparsak önemli olur? Mesela [ailenin bütünlüğü konusu], kadın ve aileyi karşı karşıya getirilebiliyor. Kadının güçlenmesini aileye bir risk olarak görebiliyoruz." (Kadın, Yönetim Kurulu Üyesi)

Aile kurumu, her koşulda birliğini sağlamalı mıdır? Aile bazı yönleriyle geçimsizliği de beraberinde getirebilir. Ailenin kurulması kadar dağılması da olağandır. Aileye gereğinden fazla anlam yüklemek ve yaşanan sorunları göz ardı etmek bilhassa kadına büyük zararlar verebilmektedir. Bu durumu görüşülen STK üyelerinden biri şu şekilde ifade etmiştir:

"Bu aile niye önemli; orada çocuğu korumuyorsa, kadını korumuyorsa, bir huzur yoksa orada, iyi bir üretim gerçekleşmiyorsa... Maddi anlamda söylemiyorum; sevgi anlamında, güven anlamında... O zaman o aile gene bir aile modeli olarak korunması gerek midir, aile midir? Bunları da konuşmak 
lazım. Aileyi bir arada tutmak demek sadece kadın ve erkeğin, çocukların zorunlu olarak yaşadığı bir mekân olmaktan çıkması lazım. Biraz biz aileyi koruyalım da bütün sorunlarn görmezden gelelim mantığına büründürüyoruz bir yerden sonra iși. Ben bunların her birinin kendi içinde sorunlu olduğunu düşünüyorum." (Kadın, Yönetim Kurulu Üyesi)

Aile, çeşitli roller çerçevesinde birbirine etki eden insanlardan meydana gelmiştir ve üyelerinin yaşamdan duyduklarn tatmini artırmada en önemli kurumdur. Ailenin bir kurum olarak yürüttü̈̆ü faaliyetler aile bireyleri arasında roller șeklinde dağıtılmışıtır (T.C. Başbakanlık Aile Araștırma Kurumu Başkanlığ 2002: 17). Ailedeki temel sosyal ve ekonomik konularda karar verme ve sorumluluk dağılım biçimi, aile bireylerinin, özellikle de kadının ve erkeğin üstlendiği roller ile yakından ilgilidir. Ancak aile denilince sıklıkla akla gelen çekirdek aile formu ve bu kurumu oluşturan bireylerin farklllaşan rollerinin ötesindeki farkh aile tipleri bazı katılımclar tarafindan ortaya konulmaktadır. "Yani her halükârda bir aileyi bir karı koca veya çocuktan oluşan bir aile illa bir aile olmak zorunda değil, belki anne çocuk bir aile olacak onları da görmek lazım." (Kadı, Yönetim Kurulu Üyesi).

Çoğu zaman kadınların işgücüne katılımı olumlu bir gelişme olarak değerlendirilirken, genellikle ekonomik olarak özgürleşmelerini de beraberinde getirmektedir. Ancak kadının çalışması her zaman bu sonucu doğurmamıştır. Aile içindeki sorumluluklarını ve iş yaşamındaki rollerini aynı ölçüde yerine getirme zorunluluğu, çalışan kadın açısından bir özgürleşme kadar onu baskılayan yıpratıcı bir süreç olabilmektedir (Adak 2007). Ailedeki bu geleneksel nitelikler yüzünden bilhassa kadının zarar gördüğü düşünülmektedir. Bir dernek yöneticisi bu durumu şu şekilde gözler önüne sermiştir:

"Bizim ailelerimizin en büyük sorunu ailenin bütün yükünün kadının üstüne yüklenmesi ve babaya para kazanmanın dışında hiçbir sorumluluk atfedilmemesi. Eğer baba para da kazanmiyorsa ıskartaya çıkıyor Bauman'ın dediği gibi. Para kazanmayan erkek hiçbir işe yaramıyor, çünkü ona tanımlanmıs tek görev para kazanması. Çocuğun ahlaki eğitimi, çocuğun okul başarısı, ailenin diğer bireyleriyle iletişim kurması vesaire gibi şeyler daha çok kadın üzerinden yürüyor Türk toplumunda. Öyle olduğu için de boşanma vs. olduğunda çocuğu, -aslında İslam hukukuna göre babayadır ama- hemen anneye veriyoruz. İslam hukukunda bu çok eşlilik, kadın erkek eşitliğinde erkeğin üstün olması vs. meselelerde erkekler çok aktif bilgiye sahip ama evdeki sorumluluklar mesele olduğunda hiç o geleneksel bilgiyi takmıyorlar. Yani ben baba eksik diye düşünüyorum ailede." (Kadın, Yönetim Kurulu Üyesi) 
Kadının ücretli bir işte tüm gün çalışması cinsiyete dayalı geleneksel iş bölümüne dayanan aile formundan farklı bir aile yapısını gösterir (Arpacı \& Ersoy 2007). Kadın ve erkeğin istihdama katıldığı bu yeni aile formunda evde de hakkaniyetli bir iş bölümü, ailenin bekası açısından önemlidir. Kadının geleneksel olarak üstlendiği rollerin ebeveynler arasında adaletli bir şekilde bölüştürülebilmesi sıklıkla tartışılmaktadır. Muhafazakâr bir STK temsilcisi bu değişimin zihniyet bazında da olması gerektiğini şu ifadelerle dile getirmiştir:

"Bir zihniyet dönüşümünün gerçekleşmesi gerekiyor. Kadın aile kurduktan sonra, çocuğu olduktan sonra bu iki şey arasında, işiyle yaşamı arasındaki o dengeyi sağlamadığ zaman ciddi çatışmalara dönüşebiliyor ailede. Ve sonunda istenmeyen yerlere gidebiliyor, bu bir sikıntı." (Kadın, Uzman)

Çocuk bakımının her iki ebeveynin de sorumlulığunda olduğu toplumsal olarak kabul edilen ülkelerde anne ve baba çocuk bakımında birlikte görev alırken, geleneksel ilişkilerin kısmen de olsa devam ettiği toplumlarda bu görev babadan ziyade anneye verilmektedir (Adak 2007). Bu çerçevede dindar bir STK yöneticisi kadın iş hayatına atılsa da ev hanımı olsa da ailede paylaşılması gereken görevleri tek başına üstlenmemesi gerektiğini şu şekilde ifade etmiştir:

"Benim çocuklar küçükken sınıf toplantısı olurdu. Gelmezdi veliler. Babalar hiç gelmez. Israrla birkaç babayı getirirdik. Bütün toplantılarda anneler olur, iki üç tane baba olurdu. Babalarn dahil edemiyorsun buna. Mesela bazı annelerin işi çok yoğun, kendilerini baba yerine koyuyorlar. Yani erkeğin işini de yapıyorlar. Ama baba da bir yerden tutmalı. Çocuk babayla da bazı işleri yapmalı. Erkeklerimizde de var bu hata, gelmiyorlar. Babanın eğitimini veya babanın işini anne yapmasın. Erkek çocuğuna da kızlara da baba lazım. Beraber vakit geçirmek lazım babalarla." (Kadın, Yönetim Kurulu Üyesi)

Kadından evde duygularını yumuşak ve ikinci planda yaşaması beklenirken iş ortamında aklını işine vermesi istenmektedir (Hochschild \& Machung 2012). Sonuçta kadın tüm bu çelişki ve çatışmaların yarattığı iş-aile gerilimini yaşamaktadır. İş-aile çatışması olarak adlandırılan bu durum Greenhaus ve Beutell tarafindan bir role katılımın diğer bir role katılımından dolayı daha güç yapılır hale gelmesi olarak tanımlanmıştır (Adak 2007). Bu duygusal çatışmalar bir katılımcı tarafından şöyle açıklanmıştır: 
"Bir kere çalışan anneyi görüyoruz. Çalışan anne anket araștırmalarına baktığımızda, annelerin yüzde yetmis beşi, çocuğunu evde bırakmaktan, bakıcıya bırakmaktan, hep vicdan azabı içerisindeler. Bütün sorulara gelen cevaplarda yüzde ellinin üzerinde böyle. Baktığında yani bu anne vicdan azabıyla yaşıyor. Ne kadar verimli olabilir. Çocuğuna etki ettiğini, çocuğunu büyüttüğünü düşünmüyorlar mesela. Bakıcının ahlakın aldığını düşünüyorlar.” (Kadın, Yönetim Kurulu Üyesi)

Günümüzde pek çok aile, yaşam standardını belirli bir düzeyde koruyabilmek için kadının gelir getiren bir işte çalışmasına bağımlı hale gelmiştir (Arpacı \& Ersoy 2007). Çalışmak zorunda olan kadınlar işi ve ailesi arasında sıkışıp kalabilmektedir. Düzenli ve mutlu bir aile yaşamının sürdürülmesinde önemli rol oynayan ev işlerinin gerçekleştirilmesinde de temel sorumluluk kadına ait olmakta ve kadınların çoğunluğu ev işlerine bağımlı olmaktadır. Dolayısıyla, kadın ev dışında para getiren bir işte çalışsa da diğer mesleği olan ev kadınlığını sürdürmektedir (Terzioğlu 1988). Sosyal ve ekonomik olarak üstlendiği tüm görevleri dilediği gibi yerine getiremeyen kadınlar psikolojik ve fiziksel olarak yıpranmaktadır:

"Şöyle mesela, ekonomik sıkıntılarm aileye çok olumsuz etkisi olduğunu görüyoruz. Bu olumsuz etki kadın da çalışmaya itiyor, mecbur bırakıyor. Kadının çalıșmaya mecbur olması hem iște hem evde çalışması ve çocuğunu da dert eden taraf olması, yani oradaki paylaşmanın da gerçekçi bir paylaşım olmaması sorumluluklar açısından kadını çok yıpratıyor, sinirleri daha gergin hale getiriyor. Yani kadın çalışacaksa orada ortak bir yük paylaşımına gidebilmeli. Aile içerisinde o çok gerçekleşmiyor maalesef." (Kadın, Yönetim Kurulu Üyesi)

Geleneksel sistemde aile, içerisine girdiği toplumsal çevrenin ve alınan eğitimin etkisiyle kız ve erkek çocuklar cinsiyetlerine uygun roller kazanmakta ve toplumsal cinsiyet kimliğini edinmektedirler. Böylece kadınlar için ev ile ilgili işleri yürütme ve çocuk bakı$\mathrm{m} ı$ gibi işler öne çlkarken, erkekler için iş rolleri aile rollerinden daha önemli hale gelmektedir (Powell \& Greenhause 2010:1012). Kadının iş hayatına girmesiyle değişen rolleri bir kenara koyarsak ailelerin temel problemlerinin bu rollere uyulmadığı zaman ortaya çıktığı ifade edilmiştir: 
"Türk toplumunda aileyi güçlü kılan bir hiyerarşi var. Türk toplumundaki o hiyerarşi, yani evde bir otoritenin olması, annenin konumu, çocukların konumu, aslında bir aile içi disiplini sağlar. 0 disiplin de ailenin dağılmasın engelleyen bir şeydir. Türk toplumunda en iyi şsyin bu olduğunu düşünüyorum. Tabii bunun temelinde de manevi dinamikler var. Türk toplumundaki ailenin manevi dinamiklerde de kimsenin kimseden üstün olmadiğı ama vazife ve salahiyetlerin var olduğu kabulüdür. O kabulü getirir o manevi dinamikler. Şimdi Türk ailesinde kadın, kadın olarak değerlidir, baba da evin direğidir. Yani hani o inamıslara tekrar kavuşmamız lazım. Şu anda maalesef çok ciddi bir rol kargaşası var. Dolayısıyla da işte ortaya çıkan boşanma malûm. Çok ciddi. Rol kargaşası derken bazen evi yöneten küçük bir çocuk olabiliyor, bazen kadın hem evin erkeği hem kadın hem annesi hem babasi gibi davranabiliyor. Erkekler bir bakıyorsunuz evde yok gibi. Dolayısıyla bunlar oradaki hiyerarşik yapıyı bozuyor. Bence en önemli șey hiyerarşik yapr yani." (Kadın, Yönetim Kurulu Üyesi)

Ailede erkeğin rolü yalnızca para kazanmak olunca da birtakım sorunlar oluşmaktadır. Bu algı yüzünden kadınlar aile için daha fazla görev üstlenmişlerdir. Burada erkeklerin görevlerini eksik yapmalarından ötürü bir eleştiri yapılmıştır:

"Maalesef bizim insanlarımı kitaptan uzak olduğu gibi seminer ve eğitimlerden de çok uzak. Özellikle erkeklerimiz hiç katılmıyor. Kadınların yine iyi kötü tamir edici yönü var, bir șeyler öğrenmeyi seviyorlar ama erkekler para kazanma dışında bir rolü olduğunu unuttular. Bu da en büyük acı işte. Toplumu idare eden, hani idare eden derken, meclise baktığımızda yüzde yetmişi erkek, bu erkeklerin çok daha donanımlı olması lazım yani aileyle ilgili düşünür hale gelmeleri lazım." (Kadın, Koordinatör)

Cinsiyetlere atfedilen anlamlar, kadın üzerinde baskıya sebep olmaktadır. Erkek ve kadının aynı görevlere sahip olmayışı beraberinde aynı haklara sahip olmayışını da getirmiştir. Ancak bu durum bazı STK idarecilerince erkeğe sınırsız hak tanınması olarak yorumlanmıştır. Erkeğin Türk toplumundaki yeri dolayısıyla bu nevi düşüncelerin zuhur etmesi bir bakıma normaldir. Ancak kad1nın erkekle eşit görevler talep etmesi erkeğin ailedeki görevlerini üstlendiği anlamına gelmemiştir. Bu sebeple aile içi görev dağılımının bozulmuş olmasının suçu, erkeklerin ve babaların üzerine atılmıştır. Bu pencereden bakıldığında zorba, despot, gaddar bir aile reisi imajıyla erkeklerin tasvir edildiği görülebilmektedir. 
"Erkeğin güçlü olmasının kadın üzerindeki her türlü şeyi yapabilme gücüne ya da çocuk üzerindeki her türlü [şeyi] yapabilme hakkı ve yetkisinin ona verilmiş olmasıyla da bağdaştırıldıkların düşünüyorum. ... Bir de böyle bir üstünlük tarafi var. Yani aileyi bence zedeleyen şeyler. Çünkü artık geçmişteki toplumda yaşamadığımız için bugünkü toplumda kadın başka bir bilinçle bakıyor hayata. Erkek bu bilinçten uzak kaldıkça aradaki mesafe açllyyor ve erkek şöyle düşünmeye başlyyor: Dün öyleydi bugün ne değiști? Eşim aynı eș, ne değişti? Ama kadın artık itiraz ediyor çünkü kadın başka bir bilinçte. Artık ben de seninle eșit yerden hayata bakmak istiyorum diyor. Beni eşitin olarak kabul et! ... Eşit olmak, eşiyle eşit iliş̧i kurmak istiyor." (Kadın, Yönetim Kurulu Üyesi)

Kadınların iş hayatına atılmalarının bir sonucu olarak aile görevlerinin değiştiği ifade edilebilir. Bu rol ve görev değişikliği çocuk bakımında annenin omuzlarına gereğinden fazla sorumluluk yüklemiştir. Bundan kaynaklanan aile içi sorunlar yaşanmaktadır. Çocukların eğitiminde ilk akla gelenin anne olmasının aile içi görev dağılımını olumsuz yönde etkilediği düşünülmüsstür. STK'ların düzenlediği eğitimlerde de çocuk eğitimi için kadınlar, annelik görevini layıkıyla ifa edebilmek için eğitimlere katılım sağlamakta iken babalar bu tür eğitimlere katılma oranlarıyla annelerin yükünü hafifletmedikleri algisı oluşturmuşlardır. Ancak her kadının iş hayatında olmadığı ancak çoğu erkeğin bilfiil ve tam zamanlı çalıştığı düşünülürse bu nevi eğitimlere katılma oranının erkeklerde az olmasının sebebi açıklık kazanacaktır.

"Öncelikle bu tür eğitimlere babalarn dâhil olmaması büyük bir problem. Saatlerin uygun olmaması bir faktör olabilir evet ama çoğunluk bu işin sadece annenin yükümlülüğünde olduğunu düşünüyor. Türkiye genelinde çocuk eğitimi dediğimiz zaman annenin eğitimi akla geliyor. İçinde bulunduğumuz yüzyllda babanın kesinlikle dahil olması gereken bir süreç var. Tek ebeveynli çocuklar var maalesef, baba var ama tek başına annenin büyüttü̆ğü çocuklarla karşı karşıyayız. Bazen anne de olamıyor, annenin çalışma hayatına katılmasıyla ebeveynsiz çocuklar karşımıza çıkıyor. Dolayısıyla bizim istediğimiz şey babaların sayısını artırmak." (Kadın, Direktör)

Geleneksel olarak, işler ve sorumluluklar ailede cinsiyet gözetilerek paylaşılmaktadır. Geleneksel aile çerçevesinde erkekler tamir, bahçe bakımı gibi işleri yaparlarken; kadınlar kendilerine verilen yemek pişirme, bulaşık yıkama ve ev temizliği gibi işleri yapmaktadırlar (Şafak, Çopur\& Özkan 2006). Bu geleneksel tutum kadın- 
ların iş hayatına atılması ile değişime uğramıştır. Bu değişimden en çok etkilenenlerden birisi de ev hanımları olmuştur. Çalışan kadınların sahip oldukları olanaklar ve toplum nezdindeki itibarı dolayısıyla ev hanımları geleneksel rollerini sorgulama yoluna gitmişlerdir. Ailede üstlendikleri görevlerin değersiz addedilmesi de onları dışarıda çalışmaya yönlendirmiş olabilir. Ev hanımlarının yaptıkları işlerin işten sayılmamasına ve değersiz görüldüklerine yönelik şu ibareler nakledilmiştir:

“...Ev hanmmlarn önemli bir kitle, ev kadınlarmmn kıymeti bilinmiyor. Ne [ev hanımları] kendilerinin önemini biliyor ne de çevresi yaptığı işi takdir ediyor. Bizim hareket noktamız bu oldu. Ev kadınlar bilinçlensin istiyoruz, sadece ev işleri konusunda değil toplumsal konularda çözüm üretecek şekilde güçlendirmek. ... Ev hamımlarn yani ashnda çok iş yapıyorlar ama ev işi yapıyorlar, onun farkında değil takdir görmüyor. Mesela kocası geliyor sabahtan beri ne yaptın [diyor.] Hâlbuki o sabahtan beri uğraşıyor. ... Mesela evi birine temizletebilir ama evin işini kendisi yapıyor, çocuğunu bakıcıya baktırtabilir ama kendisi çocuğa bakıyor, yemek yapıyor yemeği hazır alsanzz sağllksız. Hem bu yönü var hem de takdir edilmeme var. Çalışanlar [kadınlar ise] bazen evini ihmal edebiliyor. Biz bu arada kadınların adaletli bir yerde durmasın istiyoruz." (Kadın, Yönetim Kurulu Üyesi)

Ev kadınlarının üretkenliklerini artırarak sosyal hayattaki konumlar1nın daha anlaşılabilir ve değerli hale getirilebileceği kanaati vardır:

"Mesela okullarda çocuklara soruyoruz diyorlar. Anneniz ne is yapıyor diye. [Annesi ev hanımı olan çocuk] benim annem bir şey yapmıyor [diyor.] [Annesi dışarıda çalışan çocuklar] şurada burada çalışıor [diyor.] Hayır, annesi de evde çalışıyor evde emekçi, yani ev hamımliğ yapıyor. Çocukta da o güven yok, annede de o güven yok. [Ev hanımlarına da] ne yapryorsun denildiğinde ben bir şey yapmiyorum [diyor] ve çalışan hanımlara hayran. Hâlbuki evde de üretilebilir. Bir de çevremizde gördüğümüz fakir hanımlar var el işleri yapıp satıyorlar. [Bu da] üretmektir. Çok tembeller, [ev hanımlarl] bir şey üretmiyor. Halbuki yapabileceği şeyler var. Bazısı çok çocuklu. Herkesin yapabileceği şseyler var. O hanımlara farkındalık kazandırmak istiyoruz. Bir de anne eğitildiği zaman toplumu eğitmiş oluyorsunuz, biz de toplumu eğitiyoruz. Çıkış noktamız bu. Ev kadını önemli." (Kadın, Yönetici)

Ev hanımlığı değersiz görüldüğü için genç kadınların evliliğe pek sıcak bakmadıkları bir katılımcı tarafından şu şekilde ifade edilmiştir: 
"Bir de günümüzde evlenmiyor genç kızlar. Yüksek lisans bitsin de bitmeden [olmaz deniliyor]. 0 zaman da gecikiliyor yani. ... Ama biz aileyi önemsediğimiz için diyoruz ki çok gecikmesin yani gençler ev kadınlı̆ı̆ı önemsesinler yani evlenip de ev kadın olmak onlara sıkıntı gelmesin." (Kadın, Yönetici)

Ev hanımlığının toplumda küçümsenmesi, kadını aile kurmaktan uzaklaştırmaktadır. Ev hanımlığı bir vasıfsızlık değildir. Buna ilişkin şunlar söylenmiştir:

"Kadın bugün ev hanımı olmaktan hoşlanmıyor, ben ev hanımıym demekten utanyor. Vasıfsızlık olarak değerlendiriyor veya çocuk sayısının artmıs olmasindan üzüntü duyuyor. Ben üç çocuğum var demeye utanmıyorum ashında keşke daha çok çocuğum olsaydı diyorum. Ev hanımı olmaktan utanmıyorum. Tam bir ev hanım mıyım? 0 statüde de değilim ashnda ama yine de kendime ev hanımıуm diyorum. Bunu niye diyoruz? İnsanlara bir özgüven gelsin, ev hanımıysa ev hanımıyım [diyebilsin.] Ev hamım çok utamılacak [bir şey] değil hatta hiç utanılacak bir şey olduğunu düș̈̈nmüyorum. Kimse düşünmüyor ama bu toplumsal baskı ve hedefsizlik insanları savurdu, aileleri savurdu. Çok çabuk deformasyona uğradık birçok noktada." (Kadın, Yönetim Kurulu Üyesi)

Ev hanımlarını bilinçlendirerek anne-çocuk arasındaki kuşak farkından kaynaklanan eğitim ve kültür alanındaki eksikliklerinin giderilebileceği ifade edilmiştir:

"Hanımlar eğitilmeli ki evinde de olsa çalısssa da bazı şeylerin farkında olabilsin. Bir de bazen çalışma yaptığımız yerler oluyor. Mesela o çalışma yaptı̆̆ımı yerlerde de gelmişler aileler İstanbul'un bir semtine. Anneler köyden geldiği gibi kalmış. Ama çocuklar okumuş, ilerlemiş. Bu sefer annelerini beğenmiyorlar. Anne de hâlâ köydeki gibi yaşamaya devam ediyor. Anneleri eğiterek bilinçlenmelerini istiyoruz." (Kadın, Yönetici)

\section{Ailede Baba}

Psikolog Nuttin babaların çocuklar üzerindeki etkisi için şöyle der: "Baba ile çocuklar, özellikle de yetişkin oğullar arasındaki sempati ilişkileri ileride insanın, sosyal ve moral davranışlarına hükmeden, kişiliğin gelişmesi bakımından son derece önemlidir” (Çiftçi 1991). Babanın ailedeki rolünün önemine dikkat çeken bir STK yetkilisi kadın, aileye yönelik yaptıkları çalışmalarda kadını tek başına ele aldıklarında etkin ve kalıcı çözümler üretemediklerini dile getirmiştir. Dolayısıyla da aileyi ilgilendiren tüm konularda babayı da 
sürece dâhil etmenin önemli olduğunu vurgulamışlardır. STK yetkilisi kadın, aile ve kadın üzerine yaptıkları çalışmalarda en büyük sıkıntının, baba eksikliği olduğunu şöyle ifade etmiştir:

"Ailelerde baba yok. Bizim ailelerimizin en büyük sorunu ailenin bütün yükünün kadının üstüne yüklenmesi ve babaya para kazanmanın dışıda hiçbir sorumluluk atfedilmemesi. Eğer baba para da kazanmiyorsa ıskartaya çıkıyor Bauman'ın dediği gibi. Para kazanmayan erkek hiçbir işe yaramıyor, çünkü ona tamımlanmış tek görev para kazanması. Çocuğun ahlaki eğitimi, çocuğun okul başarısı, ailenin diğer bireyleriyle ilişki kurma, iletişim kurma vesaire gibi şeyler daha çok kadın üzerinden yürüyor Türk toplumunda." (Kadın, Yönetici)

Bu eksik baba figürünün muhafazakâr ailelerde de sıkça rastlanan bir durum olduğunu muhafazakâr bir derneğin yöneticisi kadın ise şu çarpıcı cümlelerle dile getirmiştir:

“...ama pratikte en fazla evde babann olmayışı sorun diye düşünüyorum. Mesela iște bu bizim bir șey grubu vardı zamanında entelektüel erkekler grubu, bunlar her akșam kahvede bir yerde toplanyorlar. Sorsanz kahve ama bunlar aym zamanda entelektüel şey de yapıyorlar, oyun da oynuyorlar, onlar için hoş bir ortam. Bunlarm eşlerinin hepsi antidepresan kullanyyordu, çocukları babaların görmeden büyüdüler. Bunlarm hepsi bugün herkesin bildiği isimler, bunlar dindar camiadan ve bu insanlar nasıl, ne yapılacağlni topluma söyleyen kanaat önderi olarak geçen isimler ama ülkeyi kurtaracağım derken kendi ailesini kaybediyor." (Kadın, Yönetici)

Eğitim üzerine odaklanan bir STK yetkilisi ile yapılan görüşmede ise aile çalışmalarının sadece anne ve çocuk üzerine olmayıp babalık eğitimine de yer verdiklerini dile getirmiştir. Anneye ve çocuğa karşı olan baba tutumunda bölgesel farklılıkların da olduğunu dile getiren erkek yetkili, "Acıbadem gibi elit ve biraz kalburüstü yerlerde anneye olan katkıya ve çocuğa önem verilirken, Anadolu gibi biraz daha ataerkil toplumlarda babanın bakışı değişiyor" demiştir. Bu görüşü uzman psikolog Kuzucu ise Russell'ın şu sözleriyle desteklemektedir: Babanın eğitimi arttıkça, daha demokratik ve esnek bir cinsiyet rolüne sahip olan baba, çocuk gelişimi konusunda daha çok rol alır (Kuzucu 2011).

Erkek bir yetkili, geleneksel erkek ve babalık yaklaşımlarını değiştirip babaların çocuk gelişiminde daha aktif rol alabilmeleri için eğitimler düzenlediklerini söylemiş ve bunu şöyle açıklamıştır: 
"Nüfus hızla geleneksel birleşik aileden, modern çekirdek aileye dönüşüyor ama kafa değişmiyor. Babalar hâlâ çocuğun yönlendirilmesinde kendilerini sorumlu görmüyor, böylece sorumluluk diğer tarafa yığgllyor." (Erkek, Yönetici)

Seküler bir STK temsilcisi de babalık rollerine ilişkin yukarıdaki görüşlere benzer bir tutum takınmıştır. Yetkili, aile üzerine yaptıkları çalışmalarda erkeklere ulaşmanın zor olduğunu, genellikle çalışıyor oldukları için eğitimlere katılım ve süreklilik sağlamada sorunlar yaşadıklarını dile getirmiştir.

Muhafazakâr bir STK yöneticisi ise, bazı STK'lardan farklı olarak, ailede baba figürünün hâlâ bir araya getirici ve otorite sağlayıcı olduğunu, bunun da aile yapısını olumlu yönde etkilediğini dile getirmiştir. Bununla birlikte, aile konusunda STK'ların nasıl bir yol izlemesi gerektiğini ise şöyle cevaplandırmıştır:

“...aile bir bütün olarak ele alıp... Yani biz baștan beri şunu düşünüyoruz, sadece annenin ya da sadece babanın eğitilmesi doğru bir yöntem değil. İkisi birlikte eğitilmeli. Hatta ikisi aym seminerde bir arada oturtulup dinletilmeli. En verimli şeklin bu olduğunu düşünüyoruz ki tutarlllk olsun. Karşllkh konuşabilsinler, tartışabilsinler, hani bir sonuç çıkabilsin. Biz STK'lar ya anneleri eğitiyoruz ya çocuklarn eğitiyoruz; ama babalarla ilgili çok az şey var demin de dediğim gibi. Ama bu bir bütün yani...” (Kadın, Yönetici)

Bu yönetici İstanbul Sözleşmesi ile kadının beyanının esas alınmas1 meselesinde erkeğin ötekileştirildiğini ve bunun yerinde bir uygulama olmayıp toplumun baba algısının değişimini şu cümleler ile vurgulamıştır:

“...devlet şu anda İstanbul Sözleşmesi ile daha çok kadını ön plana çıkardı. Kadım ben şiddetten koruyorum, aileyi koruyorum, çocuğu koruyorum diye, erkeği böyle öteledi, çirkin gösterdi. Hani burada bizim baba algımızla da bir oynama var. Hani bu politikalardan vazgeçip aileyi bütünsel olarak ve değerlerimizle düşünmeli..."

Bir diğer muhafazakâr STK temsilcisi kadın, yapılan eğitimlere babaların katılım oranının düşük olduğundan, başka faktörler olması ile birlikte babaların bunu bir ihtiyaç olarak görmediğini söylemiştir. Buna ek olarak STK'ların yaptıkları aile çalışmalarını yeterli buluyor musunuz sorusunu ise şöyle cevaplamışlardır: "Türkiye'de 
ana baba okulu yok değil; ancak daha çok belli bir kesimin yürüttüğü, içinde din eğitiminin olmadığı çalışmalardı. Dini esas alan kuruluşlarda da eğitimin gelişim boyutu ihmal ediliyordu."

Başka bir muhafazakâr STK temsilcisi ise yaptıkları çalışmalarda cinsiyet sınırlaması yapmadıkları halde daha çok kadınlara ulaşabildiklerini dile getirmiş, erkeklerin STK'larda çokça yer almamasını bir süreç içinde şu şekilde değerlendirmiştir:

\begin{abstract}
"Erkekler, yani hani şu an belli bir görüş iktidarda ya, bizim mahalle diyoruz, kendi şahsi olarak öyle diyoruz hani, objektif bir tanımlama değil ama o bizim mahallede fikir üreten, o bizim mahalleyi șekillendiren aslında geçmiş STK ve vakıflardı. Bizim güçlü bir İslamî gelenek, vakıf geleneğinden geldiği için. Ve bunların erkekleri aslında zaten siyasete geçmişler. Dolayısıyla 2012-13'lere geldiğimizde çok zayıf bir STK temsiliyet kadrosu kaldr. Aslında o doğal bir adımdı. Ben bunu değerlendirebilecek yaștayım. Çünkü bu zihniyet, yani hükümeti olușturan zihniyetin alt yapısı, beraber yola çıtığl insanlar, tabii ki onlarla devam edecek yani. Onlar fikir üretimi yapmıs çünkü. Onlar sahada çalışmış, tabii ki onlara diyecek ki gel sen vekil, gel sen şu ol, gel benim bürokratım ol diyecek yani. Aslında bu doğal bir süreçti; fakat döndüğünde, arkaya bakttğında herkes 'Aa bu iște şu STK'dan geçmiş, bu STK'dan vekil olmuş, aa o kimdi ki...' işte derken böyle insanlar için STK'lar dediğiniz gibi bir adım haline geldi." (Kadın, Yönetici)
\end{abstract}

Başka bir muhafazakâr dernek yöneticisi ile yapılan mülakatta da benzer problemler vurgulanmış, babalar da dâhil olmak üzere aile fertleri arasında ciddi bir iletişimsizliğin olduğu ve bunun da aile yapısını olumsuz etkilediği belirtilmiştir. Babaların iletişimsizlik probleminin yanında, çocuğun bakımı ve eğitimi hususunda ilgisiz oldukları ve sorumluluk almaktan kaçındıkları vurgulanmıştır.

Yönetici ve psikolog olan bir kadın katılımcı, devletin sorunlu ebeveynlere sahip olan çocukların himayesini üstlenmekle beraber, o sorunlu anne ve babalara ciddi maddi yardımlarda bulunduğunu söylemiş; fakat devletin bu anne ve babaları psikolojik olarak da desteklemesinin gerektiğine dikkat çekmiştir. Ailenin güçlü yönlerinin neler olduğu konusunda ise ailede bir hiyerarşi olduğuna ve babanın rolüne şu şekilde değinmiştir:

“...tabii bunun temelinde de manevi dinamikleri var, Türk toplumundaki ailenin manevi dinamiklerde de kimsenin kimseden üstün olmadığ ama 
vazife ve salahiyetlerin var olduğu kabulüdür. O kabulü getirir o manevi dinamikler. Şimdi Türk ailesinde kadın, kadın olarak değerlidir, baba da evin direğidir." (Kadın, Yönetici)

Uzun yıllardır kadın ve aile üzerine çalışan bir vakıf temsilcisi ise çalışmalarında babaların katılımının çok az olduğunu şu şekilde dile getirmiştir:

"20 yıllık bir projeden bahsediyorum size. Yaklaşık olarak 100'e yakın ailemiz geldi geçti. Bunların yüzde kaçının babası var derseniz yüzde 20-30'u geçmez bu oran. Babamın belki sağllk problemi olabilir. Babanın sorumsuzluğu olabilir, ya da evde olmasına rağmen çalışmak istemiyor ama babalara yönelik eğitimlerimizde çok cevap alamıyoruz." (Kadın, Yönetici)

\section{Türkiye'de Ailenin Güçlü Yönleri}

Kıray’a göre her sosyal yapı, "bu yapıyı meydana getiren sosyal müesseselerin, insan ilintilerinin ve bunların karş1lıklı münasebetlerinden doğan sosyal değerlerin birbirlerini karşılıklı olarak etkiledikleri bir bütündür" (Kıray 1999: 95). Aile kurumu da bu sosyal yapılar içerisindeki en temel unsuru oluşturur. Tarih boyunca aileye dair yapılan tanımlar ve atıflar oldukça çeşitlilik arz etmektedir. Türk Aile Yapısı Özel İhtisas Komisyonu aileyi, Türkiye’yi kendi koşulları doğrultusunda, "kan bağlılığı evlilik ve diğer yasal yollardan aralarında akrabalık ilişkisi bulunan ve çoğunlukla aynı evde yaşayan fertlerden oluşan, fertlerin cinsel, psikolojik, sosyal, kültürel ve ekonomik ihtiyaçlarının karşılandığı; fertlerin topluma uyum ve katılımlarının sağlandığ 1 ve düzenlendiği temel bir toplumsal birim" olarak tanımlamıştır (T.C. DPT 1989).

Aile, bireylerin toplumsallaşmasının ilk adımı olmakla birlikte; toplumun dinî inanışlarını ve geçmiş tarihinden süregelen adet ve geleneklerini gelecek nesillere aktarmak noktasında önemli bir fonksiyona sahiptir. Ailenin bu fonksiyonundan ve STK'lar ile mülakat bulgularından yola çıkarak, Türkiye'de aile yapısına yön veren en önemli unsurları genel hatlarıyla "Türkiye aile geleneği" ve "İslam inancının şekillendirdiği Türk aile modeli" başlıkları altında değerlendirebiliriz.

Türkiye aile geleneğinin kökleri, İslamiyet öncesi Türk aile geleneğine dayanır. Türk-İslam sentezinin ideologlarından Kafesoğlu 
(1997), Türklerin, dünyanın dört bucağına dağılmalarına rağmen varlıklarını korumalarına gerekçe olarak aile yapısına verdikleri büyük ehemmiyeti vurgulamış ve buna delil olarak da Türk dilindeki, başka milletlerde rastlanmayan zenginlikte mevcut olan akrabalık nüanslarını göstermiştir (s. 227). Eski Türklerdeki aile yapisı bu ve benzer yönleriyle incelendiğinde, günümüzde ailenin en güçlü yönleri olarak tespit edilen aile ve akraba bireyleri ile olan sıkı bağ, yardımlaşma ve zor günlerdeki dayanışma özelliklerinin o zamanlarda da mevcut olduğunu görmekteyiz. Mülakat yapılan STK yönetimi içerisindeki katılımcılara, ailenin en güçlü yönlerinin neler olduğuna dair yöneltilen sorulara verdikleri cevaplar şöyledir:

"Yani her şeye rağmen merhamet ve atalara sayg, atalar kültünden dolayı çok değişmedi. Değişeceğini de düşünmüyorum. Bu çok olumlu bir şey. Tabii bunu neye kıyasla güçlü yönleri dersek, Batı toplumuna göre. Ben hâlâ insani bağların çok kuvvetli olduğunu, bütün yozlaşmaya rağmen büyüklere saygının, küçüklere sevginin de devam ettiğini düşünüyorum büyük oranda. En güçlü yönümüz bu aile olarak, zor günde birleşme mevhumu. Dayamışmanın hâlâ çok güçlü olduğunu düşünüyorum." (Kadın, Yönetici)

İslamiyet öncesi dönemlerdeki Türk ailesinin genel özelliklerine bakıldığında; ailenin hiyerarşik yapısında gücü ve otoriteyi elinde bulunduran kişinin baba olduğu ve aile içindeki himayeci örgünün, siyasal sistemi de belirleyen bir karaktere sahip olduğu görülmektedir (Ersöz 1991). Bu hiyerarşik aile modelinin günümüzde de kısmi olarak değişime uğramakla birlikte, devam etmekte olduğu tespit edilmiştir. Ailedeki hiyerarşik yapı ile kastedilen olgunun bir üstünlük-alçaklık göstergesi olmayıp; İslam'da zikredilen "kavvâm olma", yani fazla sorumluluk verilen bireyin, yetki olarak da o oranda fazlalığa sahip olması kastedilmektedir. Bu hiyerarşik yapının ailedeki otorite ve disiplini sağladığı, ebeveynlerin birbirleri ve çocukları ile; çocukların da ebeveynleri ile sağlıklı bir iletişim ve ilişki ağı oluşturmalarını sağladığı söylenebilir. Mülakat yapılan bir katılımcı, ailenin güçlü yönlerine değinirken, ailedeki hiyerarşik yapının gücüne dair şu tespitlerde bulunmuştur:

“...Evet, biz hep gücsü̈z ailelerle karşı karşıyayız belki ama ben Türk toplumunda aileyi güçlü kılan değerlerin [olduğunu düşünüyorum]. Ailede bir 
hiyerarşi var. Türk toplumunda o hiyerarşi, yani evde bir otoritenin olması, annenin konumu, çocukların konumu, aslında bir aile içi disiplini sağlar, o disiplin de ailenin dağılmasın engelleyen bir şeydir. Türk toplumunda en iyi şeyin bu olduğunu düşünüyorum. Tabii bunun temelinde de manevi dinamikler var. Türk toplumundaki ailenin manevi dinamiklerde de kimsenin kimseden üstün olmadığı ama vazife ve salahiyetlerin var olduğu kabulüdür. O kabulü getirir o manevi dinamikler. Simdi Türk ailesinde kadın, kadın olarak değerlidir, baba da evin direğidir. Yani hani o inanışlara tekrar kavuşmamız lazım. Şu anda maalesef çok ciddi bir rol kargaşası var. Dolayısıyla da iște ortaya çıkan boşanma malûm. Çok ciddi rol kargaşası derken bazen evi yöneten küçük bir çocuk olabiliyor. Bazen kadın hem evin erkeği hem kadını hem annesi hem babası gibi davranabiliyor. Erkekler bir bakıyorsunuz evde yok gibi. Dolayısıyla bunlar oradaki hiyerarsik yapıyı bozuyor. Bence en önemli şey hiyerarşik yapı yani.” (Kadın, Dernek Koordinatörü)

Türkiye'de aile, yapısal olarak geleneksel geniş aileden çekirdek aileye doğru bir yönelim içerisindedir. Türk aile geleneğini etkileyen bir diğer unsur olan kırsal yaşamdan kentsel yaşama geçişle birlikte her ne kadar zayıflamış olsa da Türklerdeki geniş aile geleneği, aile için ciddi bir güç kaynağıdır.

Türk aile toplumu tarıma dayalı bir toplumdu ve kırsal kesimlerde yaşayan insanlar için tarım en önemli geçim kaynağını oluşturmaktaydı. Tarımsal faaliyetler ise makineleşme öncesi dönemde el gücüne dayandığından aile bireylerinin sayısı oldukça önemliydi. Buna bağlı olarak Türklerdeki aile yapıları geleneksel geniş aile yapısına sahipti. Anne baba dışındaki babaanne, dede, hatta bazen hala-teyze gibi büyüklerin aynı haneyi paylaştığı bu büyük aile yapısı hem aile hem de akraba bağlarını daha güçlü kılarken, deneyimli büyük bireylerin fikirleri de önem arz etmekteydi. Aile bireyleri, karşılaşılan sorunları çözme noktasında yetersiz kaldıklarında, istişare edecekleri ve danışacakları bir rehbere ihtiyaç duymaktadırlar. Geniş aile yapısına dâhil olan aile büyüklerinin bu ihtiyacı büyük oranda karşılayabildiği tespit edilmiştir. Katılımcılar, tüm bunların akabinde geniş aile yapısının aileyi güçlendirdiğini düşünmekte ve şu ifadeleri kullanmaktadırlar:

"CCekirdek aileye dönüsüm oldu falan gibi bir klişe var ya, aslında biz çekirdek aileye geçmiş olsak bile Türk aile yapısının bence çok daha farklı bir an- 
lamda tanımlanması gerekiyor. Bizim hâlâ bağlarımız kopmamıs vaziyette. Şunu biz gözlemliyoruz, kişiler hâlâ kendi hayatlarnda verdikleri kararlarn çekirdek aile içerisinde değil, bir üst jenerasyonla paylaşarak veriyorlar. Bu ashnda aile içerisindeki istişarenin ne kadar kuvvetli olduğunu gösteriyor. Anadolu'ya doğru gittiğinizde birbirine yakın oturmalar, aym apartman içerisinde oturmalar, aile içerisinde hâlâ o istişare ortamınn kuvvetli bir şekilde yapıldığım görüyoruz. Bu aslında kișinin psikolojik anlamda iyi hissetmesine neden olabilir. Bunu güçlü bir yön olarak görüyoruz. Bu, kimilerine göre kişinin bireyselleșmesini zorlaştıriyor gibi görülebilir ama biz hata yapma payım azalttı̆̆ın düşünüyoruz. Ama onun dışında İstanbul'da bizim gözlemlediğimiz kişilerin artık çok, ailelerin birbirinden uzak oturuyor oluşu ciddi bir problem gibi gözüküyor. Yaşlı bakımında mesela dışarıdan hizmet aldiğımız bir sektör var. Yani bu iște ne kadar sağllkh bir psikoloji oluşturuyor toplum üzerinde, buna bir bakılması gerekiyor." (Kadın, Uzman)

Türkiye'de 1950 yıllarında başlayan tarımda makineleşme ile insan gücüne duyulan ihtiyaç azalmış ve insanlar geçimlerini sağlayabilmek için köylerinden kente göç etmişlerdir. Köyden kente göç ile birlikte, genellikle anne-baba ve çocuktan oluşan çekirdek aile modeli yaygınlaşmaya başlamıştır. Ancak sanayileşme ve göç ile ortaya çıkan bazı sosyal ve ekonomik problemler, her ne kadar aile yapısını etkilemiş olsa da yerleşik kültürün etkisi ile aileler aldıkları karar ve yapacakları işlerde büyüklere danışma ve onların tecrübelerinden faydalanmayı hâlâ bir zenginlik olarak görmektedir. Yapılan mülakatta bir kadın katılımcı bunu şu şekilde ifade etmiştir: "Aile güçlü bir yapı. Karar mekanizmaları büyüklere danışma yoluyla ilerliyor, bu da aileyi güçlü kılıyor.”

Katılımcılar, güçlü ailenin problemsiz aile demek olmadığını, her ailede problemlerin ortaya çıkmasının gayet tabii olduğunu; esas önemli olanın ailenin bu problemleri çözebilecek bir mekanizmaya sahip olabilmesi olduğunu söylemişlerdir. Bu mekanizmanın önemli bir kısmını ise aile büyüklerinin temsil ettiğini ifade etmişlerdir:

“...Zaten güçlü aile dediğimiz aile, problemi olmayan aile değil ki; problemini çözebilen, bu mekanizmaya ulaşabilen, bu iradeyi gösterebilen aileleri oluşturmak istiyoruz." (Kadın, Yönetici)

Genel bulgular, Türkiye'deki geleneksel geniş aile modelinin bazı küçük problemlere sebebiyet verebilmekle birlikte aile bağlarını 
güçlendirdiğini; ebeveynin kendi anne-babalarına karşı tutum ve davranışlarına çocukların şahit olmalarının, onların ahlak ve edep eğitimini doğrudan almalarını sağladığını göstermektedir. Katılımcılardan biri, konuya dair şu ifadeyi kullanmıștır:

“...Aile bağlarımn bir arada tutma özelliği, örnek davranıslarla aktarımın sağlanması çok önemli. Aile büyükleri nasıl davranıyorsa, çocuklar öyle şekilleniyor. Ayrıca yeni nesle ailesine karşı çok sorumluluk yüklemiyoruz, buna rağmen benim ebeveynime karşı tutumum çocuklarıma örnek olmuş." (Kadın, Eğitmen)

Başbakanlık Aile ve Sosyal Araştırmalar Genel Müdürlüğü’nün 2010 yılında yapmış olduğu Türkiye'de Aile Değerleri araştırmas1, günümüz Türkiye'sinde de değişim ve dönüşüme bağlı olarak şekillenen değerler değişimine dair bazı tespitlerde bulunmuşlardır. Araştırma sonucunda, araştırmaya katılanların yüzde 83,7'si maddi ve manevi sorunlar olduğunda ilk olarak aileye başvurulması gerektiğini düşünmektedir. Ailesinin iyiliği için her türlü s1kıntıya katlanabileceğini ifade edenlerin oranı ise yüzde 90,3'tür (Ekici 2014: 217).

Katılımcılar, tüm bu etkenlerin yanı sıra, ailenin sadece kendi varlığına dayalı iç dinamiklerinin dahi tek başına bir güç olduğunu düşünmektedirler. Aile ortamının koruyucu, dayanışma olgusunu geliştiren, maddi ve manevi olarak insanı destekleyen yönlerine vurgu yapılmış; ailedeki bazı problemli yönlerin onarılması gerektiğini şu şekilde dile getirmişlerdir:

"Aile birazcık iyi bir aileyse bunun da koruyucu olduğınu düşünüyorum, doğrusu ahlaki anlamda da dayamışma anlamında da ailenin koruyucu olduğınu düşünüyorum. Stresli zamanlarda insanların sığınacağı bir liman olduğunu düşünüyorum. Her türlü şeye rağmen insann güvenebileceği, arkasında duran kadın ya da erkeğe ihtiyacının olduğunu düsünüyorum. Psikolojik boyutunun çok etkili olduğunu, hâlâ Türkiye'de bu etkinin devam ettiğini düşünüyorum. Bütün bu söylediğimiz șeyler aileyi yıpratıyor olmakla birlikte hâlâ aile kavramımız, hâlâ aile diye bir kurumumuz var. Bütün bunlar arazlar. Ama düzeltmek üzere konuștuğumuz arazlar. Yani biz başkalar gibi şöyle bakmıyoruz, burada arazlar var o halde bu aile işe yaramıyor, aileden vazgeçelim değil. Aile çok önemli burada. Böyle arazlar var, bu arazlarn düzeltmeye çalışalım. Düzeltebiliyorsak onlara bir şekilde müdahale edelim gibi bir şey.” (Kadın, Yönetim Kurulu Üyesi) 
Aile ortamını, fertler için güvenli bir ortam ve tehlikelerden korunmak için bir sığınak olarak görmüşlerdir. Özellikle çocuklar için aile ortamını, çeşitli problemler yaşanan sorunlu aileler de dahil olmak üzere, sokak veya diğer tehlikeli ortamlara nispetle daha güvenli kabul etmişlerdir. Katılımcılardan biri ise madde kullanımının, parçalanmış ailelerin çocuklarında diğer ailelerdekilere oranla daha yüksek olduğunu şu cümlelerle ifade etmiştir:

"Bağımlı gençlerin 1/20'i sadece anne babalı çocuklarmış. Kalan 19/20 kişi parçalanmış ailelerin çocukları, yani ailenin kendisi zaten bir değer, bir güç, bir arada olması bir güç. Dağılmış aile çocukları, istenmeyen aile çocukları, terkedilmiş veya boşanmış tek ebeveynli çocuk diyelim. Bağımlıların 1/20'i normal aile çocuğu 19/20'u dağılmıs aile çocukları. Ailenin kendisi de biz zaten değer diyoruz, başı başına bir değer. Dinlediğimiz, öğrendiğimiz şey, en kötü aile sartları bile yurt ortamından, sokak ortamından, yani dayak yiyen bir çocuktan -tasvip etmiyoruz ama- gene o daha güvenli çünkü sokaklarda kimseye güvenemiyorsun." (Kadın, Dernek Üyesi)

Aile, toplumsal ve dinî değerlerin ilk olarak aktarıldığı yerdir. Tarih boyunca toplumların sahip olduğu dinî değerlerin, o toplumun kültürel, geleneksel ve iktisadi hayatını doğrudan etkilediğine şahit olmaktayız. Türkler de sahip olduğu İslam inancının gerekleri doğrultusunda bir değişim ve dönüşüme uğramış ve bu değişim ve dönüşüm, toplumun temel yapı taşı olan aileye de yansımıştır. Din, aileye kutsal bir değer yüklemekte, toplumun sslahı ve refahı için aile bağlarını güçlendirmeye teşvik etmektedir. Aile birliğinin sağlam kalabilmesi için gerek ebeveynine gerekse çocuklara ve diğer aile büyüklerine çeşitli vizyonlar yüklemekte ve bu sorumlulukların yerine getirilebilmesi için bazı yaptırımlar uygulamaktadır. Katılımcılar, dinin aileyi güçlendiren bir unsur olduğuna dair düşüncelerini şu cümleler ile ifade etmişlerdir:

"Evvela aileyi kutsal kabul ediyoruz. Aile olmamizn temelinde din var, bu da çok güçlü bir mekanizma. Nikâhtan tutalım aile içi sorumluluklar vs. din kaynaklı olması aileyi güçlü kılan bir yön. Her ailede din temel faktör olmayabilir ama onlarda da geleneksel kültürümüz devreye giriyor, bu kültür de dinden beslendiği için yapıyı tutan șey aym kaynaktır." (Kadın, Koordinatör)

Ayrıca Türk toplumunun sahip olduğu cömertlik, yardımseverlik, özverili olma, diğerkâmlık ve fedakârlık gibi özellikler üzerinde de 
dinin güçlendirici bir etkisinin olduğu görülmüş, bu özelliklerin hem aile bağlarını hem de akrabalık ve toplumsal ilişkileri sağlamlaştırma noktasında oldukça etkin olduğu tespit edilmiştir. Katılımcılardan birisi şu ifadeyi kullanmıştır:

“...birçok Batılı arkadaşımın evine misafir oldum. Çay içer misin? Hayır, içmem, tamam konu kapanır. Bizde nedir, içerim demenin ayıp olduğunu bilirsin, o da zaten bir kere tamam abi öyleyse içme demez. Bunlara biraz sey yapardım ne güzel ne akıllı ne rasyonel... Simdi bizdeki bazı şeylerin çok kıymetli olduğunu düşünüyorum ve bunların en çok ailede korunduğu; dayanısma, hatırcllk, biraz geniş aile, geniş akrabalı ilişkilerinin önemi o geniş akrabalık ilişkileriyle gene kendini sorumlu hissetmek, sorumluluk üstlenmek; bunlarn kıymetli olduğunu düşünüyorum." (Erkek, Direktör)

\section{STK'lar ve Organizasyonel Yapıları}

Yapılan görüşmelerden hareketle bir STK'nın kurumsallığından söz edilebilmesi için temel şartlar olarak şunlar sayılabilir:

a. Görev, yetki ve çalışma alanlarının açık ve net olması

b. Kurumların faaliyetlerini gerçekleştirebilmek için sürdürülebilir bir mali altyapıya sahip olması

c. Yeterli insan kaynağının bulunması

d. Kurumun faaliyet ve araştırma raporlarının yazılması ve bu kaynaklara ulaşılabilir olması

e. STK yöneticisinin demokratik bir şekilde seçilmesi ve seçimin belli zaman aralıkları içinde tekrarlanabilmesi

f. Kurumların diğer STK'larla iş birliği halinde olmaları.

STK'ların görev, yetki ve çalışma alanlarım belirlemesine kurumsal açıdan bakıldiğında; görüşme gerçekleştirilen STK'ların çalışma alanları ve görevleri genel anlamıyla bellidir. Yapılan görüsmelerde STK'lar faaliyetlerinin çoğunu ailelere yönelik yaptıklarını ifade etmektedir. Fakat STK'lar aileyi bir bütün olarak değil, aile üyelerini bölerek faaliyetlerini yürütmektedir. Örneğin; bazı STK'lar sadece anneye yönelik, bazı STK'lar sadece çocuğa yönelik, bazı STK'lar ise hem anne hem çocuğa yönelik faaliyetler gerçekleştirmektedir. Dikkat edildiğinde ailede babaya yönelik yapılan etkinlikler yok denecek kadar azdır. Örneğin, “...biz burada kadına yönelik siddetten 
sonra bir paket program hazırladık ailelere yönelik. Kadınların aile eğitimiydi ama daha çok kadın üzerinden aileydi. Yine şeyi görüyorsun ailelerde, baba yok." (Kadın, Uzman). Çalışmalarında aileyi temel alan bir başka STK'da yine aileyi bir bütün olarak ele alamadiklarm ifade etmektedir. "Biz STK'lar ya anneleri eğitiyoruz ya çocukları eğitiyoruz ama babalarla ilgili çok az şey var. Ama bu bir bütün yani.” (Kadın, Yönetim Kurulu Üyesi).

STK'lar odak olarak aileyi parçacı bir anlayışla benimserken, odaklandıkları grubu bütüncül bir şekilde ele almaktadırlar. Daha açık bir şekilde ifade etmek gerekirse, mesela kadına odaklanan bir STK; kadınının eğitimi, kadının sağlığı, kadının kişisel gelişimi, kadının ekonomik durumları vb. her şeyiyle ilgilenmektedir. Bu durum şu şekilde ifade edilmiştir:

"Pozitif ayrmmcilk yaparak kızlara burs veriyoruz. Onun dıșında [bursların dışında] bu gençleri her konuda eğitmek hedefimiz ve bu gençlerin iyi bir anne [olmasın sağlamak ve] sonra da kendi geliștirdiği nesilleri de güzel yetiştirmelerini sağlamak bütün derdimiz. Çünkü biliyorsunuz kadın annedir. Türkiye'nin yarısı kadın yarısı da doğuran kadın ve bu kadınlar yetiștiriyor nesilleri. Nesilleri yetiștiren anneler." (Kadın, Yönetici)

Buna ek olarak aileyi parçacı bir anlayışla ele alan STK'lardan bazıları, aile ve üyelerini ayırmadıklarını ve çalışmalarının ailedeki her bireye yönelik olduğunu ifade etse de aileye bütüncül açıdan bakamadıkları görülmektedir. Muhafazakâr bir STK temsilcisinin ifadeleri bu noktada önemlidir:

"Aile ve kadın ayırmıoruz. Çünkü kadın platformu gibi düşünmedik. Kadın kuruluşlarmmn oluşturduğu [bir] platform[uz]. Bunun içinde afetle ilgili çalışan da var. Dinî eğitim alanında faaliyet gösteren de var. Yardım faaliyeti yapan da var. Çocuk alanında çalışan da var. Genç alanında çalışan da var. Şimdi seküler kesimde kadın çalısması [çalş̧maları] dediğiniz zaman kadın haklarn ifade edilir. Kesin net bir tanımdır. Bizim baktığımız yerdense kadın çalışmaları, ya da kadınların çalışmalarn diye düzelteyim, toplumun her kesimine ulaşacak bir şekilde yapılmaya [ve] gerçekleştirilmeye çalışılır. Hatta Gökkuşağı Derneği'nin manifestosunda kadınla ilintili olarak hayatı anlamlandıran her alanda çalışmak ele alınır. Dolayısıyla biz aile platformuna geçtiğimiz zaman amaçta bir kırılma yaşanmıyor." (Kadın, Yönetim Kurulu Üyesi)

STK'ların temel anlamda düzenli ve sürekli bir şekilde ilerleyebilmesi ve faaliyetlerini gerçekleştirebilmesi için mali altyapısını, 
gerekli araç-gereçlerini ve insan kaynağını sağlamış olması gerekir. Görüşülen STK'lara bakıldığında kurumsallaşmış STK'ların bu gerekliliklerini karşılayabilirken henüz kurumsallaşamayan STK'ların belli bir mali altyapıya sahip olamadıkları, derneğe ait bir yer edinemedikleri ve insan kaynağında da eksiklikler olduğu görülmektedir. Örneğin "Bizim derneğimiz [dernek binamız] yok, raporlayanlar var. Biz de dediğim gibi büyümediğinden [kurumsallaşamadığımızdan] dolayı... Hep aramızda yönetim kurulundaki arkadaşların iş birliğiyle götürüyoruz. Biz böyle ufak adımlarla memnunuz halimizden." (Kadın, Üye) Bir başka STK yetkilisi de yeterli ekonomik sermayelerinin bulunmamasından dolayı etkinliklerini ve odak gruplarını sınırlı tuttuklarını ifade etmektedir. Aşağıdaki ifadesiyle de bunu şu şekilde açıklamaktadır:

“... Bir fotoğrafçllk kursu verdik mesela, sergilerimiz de oldu ama bu fotoğrafçllık kursunu sertifikalı yapsaydık bu çocuğumuz belki başka bir yerde kendisi de hoca olabilirdi. Bize şunu öneriyorlar ya İSMEK'e gideceğiz ya [da] Halk Eğitim'e [gideceğiz]. Onların modülüne uymuyor bizim çalışmalarımız. Modüle uymuyorsa[k] olmuyor [kabul edilmiyoruz]. Sonuçta biz 14 bayanın kurduğu bir derneğiz. Ekonomik olarak da bizim onu karşılamamız mümkün olmuyor. Kendi kendini finanse eden bir derneğiz. Çalıșmanın kendini finanse etmesini [çalışmalarımızı katılımcılardan ücret talep etmeden] sağlamaya çalışıyoruz ama gençlikte çalıs̆manm [gençlerle çalışmada] [derneğin] kendini finanse etmesi mümkün olmuyor." (Kadın, Yönetim Kurulu Üyesi)

Hibe destekli projeler STK'lar için önemli bir mali altyapı oluşturmaktadır. Bu sebeple STK'lar her proje çağrısını değerlendirmek istemektedir. Projelere katılım sağlamak STK'ların gelişmesine olumlu katkı sağlamaktadır. Fakat her sene çıkan proje çağrısının farklı olması ve STK'ların belli bir kriter oluşturmadan firsat buldukları her ilana başvurmaları, kurumları odaklandıkları amacın dışına çıkarabilir. Kurumsallaşmış bir STK yetkilisi bu durumla ilgili şunları ifade etmektedir:

"Fonlarla da ilgili yani fon işi çıktı çıkalı herkes şuna bakıyor: Oradan fon verilir mi? Bir sürü fon var artık, dolayısıyla fonla konu az ilgili de olsa hemen dümeni biraz ona çeviriyor, bir çeșitlilik yaratıyor." (Erkek, Direktör)

Kurumsallaşan STK'ların bu konuda odak gruplarını ve amaçlarını göz önüne alarak daha hassas davrandıkları görülmektedir. Mesela 
medyanın aileye etkisiyle ilgilenen bir STK, dinî sebepler ve hedeflerinden sapma tehlikesi gibi risklerden dolayı Avrupa Birliği’nden proje almak istememiştir. Bu sebeple uluslararası destek projelerine başvurmamıştır. Yetkili bu durumu şu şekilde izah etmektedir:

"Biz bunu çok tartıştık, Avrupa Birliği'nden proje alalım mı almayalım mı, yapalım mı yapmayalım mı [diye]. Ama danıștı̆̆ımız büyük hocalarımız [kurucu üyelerimiz] yapmamamız yönünde sonuçlar çıkardılar. Bir süre sonra onlarn biz istediğimiz fikre getireceğimize, onların bizi istedikleri fikre getirebileceği yönünde bizi uyardılar. Dolayısıyla biz hiç başvurmadık Avrupa Birliği fonlarına; yapabilirdik. İç İsleri Bakanlığı'ndan çok küçük bir fon aldık." (Kadın, Yönetici)

STK'ların kamu ve özel sektörlerinden sonraki üçüncü bir sektör olmas1 göz önüne alındığında, STK'lardaki düzen ve işleyiş oldukça büyük önem taşımaktadır (Kaypak 2015). Düzen ve işleyişin sağlanmasında yeterli insan kaynağı en temel ihtiyaçlardan biridir. STK'lara insan kaynağı açısından bakıldığında kurumsallaşamamış STK'larda profesyonel bir kadro olmadığı görülmektedir. Bu tarz STK'lar işlerini daha çok kendi içlerindeki çekirdek ekipleriyle halletmektedir. Örneğin:

“...profesyonelleşmek bize uymuyor. Bir şeyi organize ediyorsun, ev kadın olarak bir misafir[in] geliyor veya bir çocuğun ateşleniyor, torunu[n] hastalamyor. Biz tam [olarak] kurumsallğ̆ oturtamadık." (Kadın, Üye)

STK'lardaki insan kaynağı düzen ve işleyişin yanında sahadan bilgi edinme, projenin yazımı ve yürütülmesi gibi konularda da büyük önem taşımaktadır. Bu anlamda STK'ların bilgiyi elde etme sürecine bakıldığında, kurumsallaşan bazı STK'lar araştırmaları için alanında uzman akademisyenlerle çalışmakta, bazıları ise bünyelerinde kadro oluşturmayı tercih etmektedir. Örneğin "Bu konulardaki araştırmaları bizzat yapmaktan ziyade konuyla alakalı çalışması olan akademisyenleri desteklemeyi tercih ediyoruz. Alanda çalışan akademisyenler[e] kaynak oluşturmaya, hedef kitle ile bir araya gelmelerine zemin oluşturmaya çalışıyoruz. Araştırmaya göre kişiler değişiklik gösteriyor" (Kadın, Yönetim Kurulu Üyesi). Bir başka kurumsal STK da sahadan bilgi edinme ve araştırma yapma gibi konularda insan kaynaklarıyla ilgili durumlarını şu şekilde belirtmektedir:

“... [burası] çok kurumsal bir yer. Şimdi [buranın] bir araștırma birimi var, [burada] herhangi bir program öneremezsin. Seminer bile geliștirseniz bu- 
nun gerçek bir örneklemde bir etki araştırmasını yapmak zorundasınız ki [ona] [bir] program diyebilesiniz." (Erkek, Direktör)

STK'ların bünyelerinde profesyonel insan kaynağı bulundurması yukarıda da belirtildiği gibi yapılacak faaliyetler ve sahip olunacak imkânlar açısından olumlu katkı sağlamaktadır. Ancak bu insan kaynağının STK'lardaki gönüllülü̈k anlayışına zarar vereceği de düşünülmektedir. Bu anlamda STK'ların gönüllülük ve profesyonel insan kaynağı açısından kendi içinde çelişkileri olduğu söylenebilir. Örneğin:

"STK'lar biraz daha kurumsallaşmaya başladı. Bunun için de siz profesyonelleri çalıștrryorsunuz benim gibi ama STK'da çalıșmanın bir ruhu var, diğerkâmlık dediğimiz o mesele var. Kendini değil başkasın öncelemek gibi bir düşünceniz olması gerekiyor. Mesela bu çalışan kişiler profesyonel olduğu zaman işlerin daha tıkırında ilerlediğini görebiliyorsunuz, daha profesyonel bakıyor meseleye ama orada da o gönüllük meselesi ne kadar oluyor. Bir noktada, bir özel sektörde çalışan kişinin mantığına bürünmek zorunda kahyorsunuz." (Kadın, Uzman)

Çocukları odağına alan kurumsal bir STK, gönüllük ve uzmanlaşmayla ilgili bu çelişkiye karşı, kurumunda hem profesyonel insan kaynağına hem de emeğinin karşılığını alan gönüllülere yer vermiştir. Görüşülen kişi bunu şu şekilde izah etmektedir:

"Bașta o kaynağı bulacaksınız ama onun da gönüllülük ilkesinin etrafında olması gerekir. Diyelim ki o çalışmalar içinde geçimini ondan sağlayan [biri var]. Bir kere onun hakkını vereceksiniz. Burada yanlış anlaşılmasın gönüllülük. Evet, o profesyonel desteği de alsanız onun bunu aym zamanda gönüllü yaptığına dikkat edebilirsiniz. Ama o çalışamın emeğini karşılayacaksını yani. Diyelim uzman olmamış ama bütünü [yapılacak işin bütününü] kavramasa da orada bu kadarın kaldırabiliyor. Öbürü geliyor ben [yapılacak işin] bu kadarm diyor. Onları bütünleștirdiğinizde, bir ekosisteme dönüștürebildiğinizde ve gönüllülükle ilgili o yürüyüşü başlattı̆̆ınıda görüyorsunuz ki orada sonuç alıyorsunuz. Ama asıl o bilen insan orada yoksa onun etrafindaki halkaların hiçbiri çalışmıyor". (Erkek, Yönetici)

STK'lar demokrasinin göstergelerinden biri olarak kabul edilmektedir (Keser \& Hışım 2016). Böyle kabul edilmesine rağmen kurumların bu anlayışı kendi içlerinde tam olarak uygulayamadığı görülür. Nitekim STK yöneticilerinin olağan dışı bir durum olmadığ1 
müddetçe mensubu olduğu STK'yı sürekli yönetmeleri ve STK'ları kendilerine bağımlı kılmaları bunun bir göstergesidir. Örneğin; medyanın aileye yönelik etkilerini inceleyen dernek yetkilisi, yapılan görüşmede 13 yıldır bu işi yaptığını ve aynı pozisyonda olduğunu söylemiştir.

Bir STK yetkilisi ise Türkiye'de kurumsallaşamayan STK'ların yönetimlerinde seçilen ve değişen bir yönetici profilinin olmadığını ifade etti. Bu bağlamda STK'ların demokratik olarak yönetilmesinin kurumsallık anlayışıla bağlantılı olduğunu ifade etmektedir. Görüşülen yetkili bu durumu şu sözleriyle açıklamaktadır:

"Çok ciddi bir zafiyetin olduğunu görüyorum. En hak temelli çalışan kurumun, STK'nin bile bir rotasyon sistemi yok. Aynı insan senelerce görüyorsunuz. Kurumsallaşma [için] oralarda bir seçimin olması, demokratik temsilin olması, rotasyonun olması [gerekir]. [Ama kurumsallaşmamış STK'lar] belli bir süre sonra 15 kişinin aktivizm yaptığ , başında da bir lider kahramanın olduğu organizasyona dönüşüyorlar. Dolayısıyla o açıdan özellikle aktivist hak temelli çalışan STK'ların kurumsallaşmalarında çok büyük bir sorun olduğunu düşünüyorum. Bunun [bu durum] tabii Türkiye'nin demokratikleşmesinden bağımsız düşünülemez. Demokrasi azaldıkça bu tip organlara katılımcıllk, temsiliyet kaçıılmaz olarak zayıflıyor. 10-15 kişinin üzerine kalıyor. Ama öyle olmasa da bu zaaf zaten Türkiye'deki her türlü hak temelli organizasyonun genel zaafi." (Erkek, Direktör)

Faaliyet raporları, bir araştırma varsa araştırma raporları STK'nın kurumsallı̆̆ının göstergelerinden biridir. Söz uçar yazı kalır anlayışıyla bakıldığında hem alanda görünür olmak hem de bir bellek oluşturmak STK'lar açısından önem arz etmektedir. Bu bağlamda yapılan görüşmelerden hareketle; kurumsallaşan STK'lar, verilerin elde edilmesi ve saklanmasına karşı oldukça hassas davranırken henüz kurumsallaşamamış STK'ların bu konudaki hassasiyetinin daha düşük düzeyde olduğu görülmektedir. Aile üzerine çalışan bir STK yetkilisi bu konuda şunları söylemektedir:

"Yani çok akademik değiliz. Hepsinin raporları anketleri var ama o anketlerin sonradan raporlandığını düsünmüyorum. Yok yani, anketler şu anda birikmiş duruyor öyle. Onlar bir rapor şeklinde çıkarılmamıs, onlar öyle anket olarak saklanmaktansa rapor olarak saklanmahydı diyorum. Data var ama sonuçlarn yok.” (Kadın, Yönetim Kurulu Üyesi)

Eğitim ve kültür temelinde çalışan bir başka STK yetkilisi de kurumlarında rapor gibi belgelere verdikleri önemi şu şekilde ifade etmektedir: "Dernek 
hafizasının olmasına çok önem veriyoruz ve her toplantımız kayıt altındadır. 2005'te kurulduğu günden beri her hafta toplanilır ve her hafta toplantı sonuçları kayıt altına alınır, raporlanır." (Kadın, Yönetim Kurulu Üyesi)

Yapılan görüşmelerden hareketle STK'ların diğer STK'larla ilişkilerinin ve iş birliğinin zayıf olduğu görülmektedir. Henüz kurumsallaşamamış STK'lar fikirsel anlamda beslenebilmek ve birbirleriyle etkileşim sağlamak için belli STK platformlarıyla iş birliği gerçekleştirse de bu iş birliğinin sahaya fazla yansımadığ görülmektedir. Daha kurumsal STK'lar ise kendisi gibi kurumsal yapıya ulaşmış STK'lar ile çalışmak istemektedir. STK'ların birbirleriyle kurdukları iletişime ve iş birliğine genel olarak bakıldığında; STK'ların devletle iş birliği yaparak fon alabileceği projelerde birbirlerinden faydalandıkları, birbirlerinin yaptıkları faaliyetleri duyurdukları, her zaman olmasa bile belli yardım faaliyetlerini birlikte yürüttükleri görülmektedir. Örneğin bir yetkili bu iş birliklerini şu şekilde dile getirmiştir:

"Bizim Türkiye Aile Platformu diye bir platforma üyeliğimiz var. Onlarla sadece bir araya gelip iște, yılda bir ya da iki, değerlendirme toplantılarn yapyoruz. Ama bu dernekler içinden bazılarl iște televizyonla ilgili, nasıl diyelim, zararl yayıları takip edip reaksiyon vermekle ilgili çalışyorlar ki çok önemli. Bazıları afiş çalışmaları yapıyorlar aileyle ilgili. Fakat çok etkili bir çalışma yok." (Kadın, Dernek Koordinatörï)

Başka bir dernek yetkilisi de diğer STK'larla iş birliği konusunda şunları dile getirmiştir:

"Ben[im] diğer STK'larla ortak yaptığım çalışmalar sadece yardım amaçll. 15-16 dernekli bir yardım kardeşliği platformumuz var. 0 platformla biz yardım faaliyetlerini düzenliyoruz, birçok yere yardım yaptık. Birçok güzel işler yaptık beraber. Bu dönemde daha çok oldu. Daha 15 gün önce Yemen için vardl, bugün Filistin için vardl... Bir de onların bir takım yaptığı yemekler oluyor, başka şeyler oluyor. Onlara da destek veriyoruz, katıliyoruz. Eğitimler oluyor konferanslar oluyor, gidiyoruz, katkı sağlıyoruz. Bak bugün mesela geldi. İște biz dediler Kudüs için eğitimler veriyoruz. Biz de dedik etrafa da duyururuz kendimiz de katılırız. Böyle işte dernekler arası alısverişlerimiz oluyor.” (Kadın, Yönetim Kurulu Üyesi)

Devletin özellikle son yıllarda STK'ları işin içine katması, onlarla ortaklık yapması, onlara hibe sağlaması daha önce de belirtildiği gibi STK'ları üçüncü bir sektör konuma getirmiştir. Kamu-STK iliş- 
kilerine bakıldığında devletin genelde kendine yakın gördüğü ve ekonomik açıdan güçlü STK'larla daha iyi ilişkiler kurduğu görülmektedir (Akçeşme 2013). Bu durumun bir sonucu olarak STK'lar zamanla siyaset için kullanılan bir basamak işlevi kazanmıştır. Bu işlev, STK'lar arası güvene zaman zaman şüphe düşürmekte, dolayısıyla iş birliğini olumsuz etkilemektedir. Bir katılımcı bu konuda şöyle yakınmıştır:

"Yani biz de şu anda [iş birliğini] geliștirmek üzere kafa yoruyoruz. Herkes önce kendi derneğini ve vakfını hedefliyor. Eğer başka bir mensubiyeti varsa onu hedefliyor. Sonra sizin yapmizı [sizin kurumunuzu] hedefliyor. [Bunun] ciddi anlamda sıkıntılı olduğunu düşünüyorum. Reklamasyona önem veren veya siyasete atlayan bir yapı değilseniz, böyle bir çizginiz de yoksa, orada hizmet üretmek de ayrica zor gelebiliyor insanlara. Sivil toplum kuruluşlarıyla birlikte çalışabilmek, dernek ve vakıfları bulușturabilmek zor. Biz özellikle [STK'ların kolaylıkla] ulaşamayacakları bilgileri çok farkh kaynaklardan toplayıp [bize gelenleri] yönlendirmeye çalışıoruz. 0 yapıyı [iş birliğini] diri tutabilmek için. Bu yapının bir parçası olarak kendilerini görebilmeleri için. Toparlamaya ve toplantılarda onlara cazip gelecek șeyler yapmaya çahıšyoruz." (Kadın, Yönetim Kurulu Üyesi)

\section{STK'larda Eleştirilen Durumlar}

Örneklemdeki STK temsilcilerine yöneltilen sorular neticesinde bu temsilcilerin diğer STK'larda yapılan faaliyetlere karşı eleştirileri olduğu görülmektedir. Bu eleştirilerin farklılaşmakla beraber benzerliklerinin olduğu da görülmektedir. Aşağıda STK temsilcilerince dile getirilen eleştirilere yer verilmektedir. STK'larda görülen genel bir problem belli bir alan veya belli bir konuya odaklanamamalarıdır. Bu, yapılan görüşmeler sonucunda açığa çıkmakla beraber daha çok aile ile ilgilenen seküler bir STK'nın temsilcisi ve çocuklar ile ilgilenen muhafazakâr bir STK'nın temsilcisi bunu üstüne basarak ifade etmiştir. Odak belirlenememesinden dolayı yapılan faaliyetlerin amacına ulaşması zorlaşmaktadır.

Odak belirlenmesi konusunda ise farklı görüşlerin ortaya çıktığı görülmektedir. Bazı STK'ların temsilcileri ailenin bir bütün olarak ele alınması gerektiğini savunurken, bazı STK'ların temsilcileri ayrı ayrı bireyler olarak ele alınması gerektiğini ifade etmektedir. Ailenin bir bütün olarak alınmasının daha doğru olduğunu savu- 
nan, dezavantajlı çocuklara aile kazandırma odaklı bir STK mensubu bunu şu şekilde ifade etmektedir:

"Yani aileyi parçalayarak yaklaşan yaklaşım bana uygun gelmiyor. İște kadın için yola çıkanlar, çocuk için yola çıkanlar, işte șimdi bir de erkekler için başladı. Erkeklerin hakların korumaya çalışanlar da var. Yani bu parça parça ele alnnacak bir şey değil. Aslında bir bütün." (Kadın, Koordinatör)

STK'larda kadının yüceltilmesinden ziyade ailenin bir kurum olarak güçlendirilmesini savunan birçok katılımcı vardır. Muhafazakâr sayılabilecek bir STK temsilcisi kadınların birçok STK'nın odağı olmasından ve bunların bazılarının aileyi temsil eder görünümde olmasından şu şekilde şikâyet etmektedir:

“...çok kadın odakh gidiyorlar, sanki aile sadece kadın haklarn gibi algilanyor. Hâlbuki bizim ailede güçlendirmek istediğimiz şey kadın haklarn değildir. Yani ya da kadının yüceltilmesi değildir" (Kadın, Yönetim Kurulu Üyesi) Maddi destek konusunda sıkıntılar çekildiğini söyleyen birçok STK yetkilisi devlet kurumlarından daha fazla maddi destek beklemektedir. Aileyi odağına almış seküler bir STK'yı temsil eden bir katılımcı bu durumu şu şekilde ifade etmektedir; "Biz çok odaklıyız ama diğer STK'lar da bence çok yok yani. Fonlarla da ilgili yani fon işi çıktı çıkalı herkes şuna bakıyor yani oradan fon verilir mi." (Erkek, Direktör) Bu ifadeden de anlaşılacağı üzere bu maddi boyut bazı STK'ların odaklarını belirlemede ve faaliyetlerini şekillendirmelerinde büyük bir rol oynamaktadır.

Dikkat çekilen başka bir nokta ise; yapılan faaliyetler göz önünde bulundurulduğunda en önemli görülen şeyin devamlılık olduğunu birçok STK temsilcisi ifade etmektedir. Devamlı olmayan faaliyetlerin bir değerinin olmadığı veya en azında amacına ulaşamayacak olması anlaşılmaktadır. Muhafazakâr bir STK temsilcisi bu konuda şu ifadeleri kullanmaktadır:

"Birkaç kere saha araşttrmamız oldu ylllar önce hani belli konularda. Ama bu devamlilı tabii, devamlilğın olmamasının birinci nedeni demin söylediğim gibi yeni kadrolar yetiştirememek; ikincisi de maddi, yani finans meselesi." (Kadın, Yönetim Kurulu Üyesi)

Burada da görülmektedir ki devamlılığın sağlanması için şartların olgunlaşması da gerekmektedir. Bu şartlar arasında yukarıda bah- 
sedilen maddi destek söz konusu olduğu gibi alttan gelen yeni gönüllülerin yetiştirilmesi de önemlidir.

Muhafazakâr STK'lar tarafindan dile getirilen başka bir şikâyet ise politikaların ve faaliyetlerin genel olarak Batılı değerlerden örnek alınarak yapıldığıdır:

“...Biz hep önümüzü Batı'ya döndürmüşüz ve onlar taklit ederek bir şeyler yapmaya çalışıoruz; hâlbuki bizim kültürümüzde aile çok önemlidir, ailenin her ferdi çok çok önemlidir. Dinimiz de zaten bizden bunu istiyor ve aile fertlerinin birbirleri üzerindeki haklarından hep bahsediliyor ama maalesef biz bunların hepsini unutmuşuz, arkamıza almışı; bunların hepsinin Batı'yla çözüleceğini zannediyoruz, aslında buna hiç gerek yok, bizim bu konuda çok derin birikimlerimiz var. Dinimizdeki insanların o birbirlerine olan saygısını, sevgisini, hürmetini, haklarını insanlar düşünse bu sıkıntıların hiçbirisi olmaz diye düşünüyorum." (Kadın, Yönetim Kurulu Üyesi)

Burada birçok muhafazakâr kurum temsilcisinin vurguladığı husus, kendi öz değerlerimize dönmemiz gerektiği olmuştur. Karşılaşılan bu yanlış temsilin ise medyadan ortaya çıktığı sıklıkla savunulmuştur. Medyanın ortaya çıkardığı bu yanlış aile temsili birçok katılımcıya göre büyük bir sorundur. Buna binaen muhafazakâr bir STK temsilcisi "kendi öz değerlerimizi" de medya ile insanlara tanıtmamız gerektiğini şu şekilde ifade etmiştir:

"Yani belki gelenekçi gelebilir bu size ama ben kesinlikle kendi öz değerlerimizi vurgulayan çok fazla çalışma yapılması gerektiğini düşünüyorum. Ama bunlar seminerler değil yani. Bunlar biraz başladı, eskisi kadar ümitsiz değilim ama insanların çok kullandığı medya kanallarıla yapılmalı. Yani televizyon, internet, her neyse, gazeteler, bizim öz değerlerimize dönmemizi sağlayacak daha yoğun çalışmalara ihtiyacımız var. Filmler çekilmeli, çizgi filmler yapılmalı, bunun sayısının artması ve insanlara ulaşabilir olması lazım. Bence STK'lar bu alana yoğunlaşmalı.” (Kadın, Dernek Koordinatörü)

Birçok STK eğitim ve seminerler verdiğinden söz etmiş olsa da hepsinin ana şikâyeti STK'ların yeterli derecede eğitim vermiyor olmasıdır. Bu sorunu dile getiren STK'lar genel olarak eğitimlerin kişilere özel olması gerektiğini ve STK'nın odak aldığı konu ile ilgili detaylı bilgiye ve kaliteli eğitime sahip olması gerektiğini vurgulamışlardır. 
Eğitim alanında başka bir şikâyet ise eğitimlerin sürekliliğidir. Eğitimlerde sürekliliği önemseyen STK'lar bu koşulun sağlanmadığ1 eğitimlerin bir değerinin olmayacağı kanaatindedir. Fakat bu sürekliliğin sağlanması için katılımcı da elzemdir. Bu husus ise başka bir şikâyeti doğurmaktadır, bu da katılımcı bulmak konusunda karşılaşılan sıkıntılardır. Özellikle erkeklere ulaşmak konusunda sıkıntı çekildiği vurgulanmaktadır. Fakat genel olarak da katılımcı bulunmasında sıkıntı çekildiği görülmektedir. Bu konuda daha çok insana ulaşabilmesi beklenen kadın odaklı muhafazakâr bir STK temsilcisi, şikâyetini şu şekilde dile getirmektedir:

"Aslına bakarsanız gönüllülük meselesi artık kalmadı diyemem ama üye olmak demek sadece kâğıt üzerinde üye olmak gibi bir noktada kahyor. Yani yapmıs olduğunuz programlara katılım bu anlamda yeterli olmuyor maalesef." (Kadın, Uzman)

$\mathrm{Bu}$ ifadeden de anlaşılmaktadır ki ne kadar üye sayısı çok gibi görünse de aslında önemli olan, yapılan faaliyetlere katılım sayısıdır. Eğitimler alanında dile getirilen başka bir husus ise verilen seminerler konusundadır. Aile Bakanlığı ile yürüttüğüu bir çalışmadan bahseden, odağı aile olan bir STK temsilcisi bu hususu şöyle dile getirmektedir:

“Şunu söyleyeyim; Aile Bakanlığı'yla, aile eğitim programı başlattı biliyorsunuz, ilk uygulayan kurumlardanı biz, ama gönderdikleri eğitimcilerin kaliteleri o kadar düşük ki... Kayıt almışım, üç beş ay sürecek, haftada iki gün olacak, böyle ciddi bir program. Yoklaması alınan [ve] takip edilen [bir program] ama orada işte benim karşıma bilim adamlarından bahseden, filozoflardan bahseden, Freud'un bilmem neyinden bahseden, hani halkın dilinden çok uzak, pratikte bir fayda sağlamayan insanlarla eğitimler yapmaya çalıştılar yani. Ve bunu biz bir iki ay yürütebildik, en son zaten bizim kendi ekibimiz karşı çıktı bu olaya." (Kadın, Yönetim Kurulu Üyesi)

$\mathrm{Bu}$ ifadeden de anlaşılmaktadır ki yapılan seminerlerde öğretici, gelen halkın seviyesinde olmakla beraber hitabetini de onlara uygun yapmalıdır. Bu alanda bir sıkıntı meydana geldiği zaman seminerler amaçlarına ulaşamamaktadır. Amacına ulaşamayan seminerler de durdurulmak zorunda kalmaktadır. 


\section{SONUÇ VE ÖNERILER}

Türkiye'de uzunca süredir aile kurumu ve ilgili alanlarda tartışmalar devam ediyor. Hızlı sosyal değişimin bir yansımasını da gösteren aileye dair tartışmalar, bir boyutuyla sivil toplumun bu sosyal değişime nasıl cevaplar ürettiğini veya üretemediğini göstermesi açısından oldukça önemlidir.

Bu sosyal değişim bir yönüyle aile yapısındaki değişimi tetiklerken diğer taraftan ailenin dönüşümü sosyal değişimin de hızlanmasına neden oluyor. Bu baş döndürücü değişim furyası doğal olarak sivil toplumun da dönüşmesine, aile odaklı hizmet veren kurumların ihtiyaçlarının, odaklarının ve faaliyetlerinin yeniden şekillenmesine neden oluyor. Diğer taraftan son yirmi yıldır devlet yapılanmasının ve uluslararası gelişmelerin de katkısıyla devlet-sivil toplum, devlet üstü güçler-sivil toplum ve sivil toplum-sivil toplum ilişkileri de dönüşüm içine giriyor (Sunar 2018). Özellikle uzun yıllar karar alma mekanizmalarından dışlanan ve devlet kurumlarına şüphe ile bakan muhafazakâr kesimin sivil toplum kurumlarının önemli bir kısmı devlet ile yakın ilişkiler kurarak seküler kabul edilebilecek kurumlara kıyasla önemli destekler almakta ve politika yapımına katkı sunmaktadırlar. Mülakat ve gözlemler çerçevesinde öne çıkan bulgular aşağıdaki gibi sıralanabilir:

* Veri toplanan STK'ların önemli bir kısmında kurumsallaşma adına sıkıntılar yaşanmaktadır.

Kurumsal yönetimin ve organizasyonel yapının kuralları net tanımlanmamıştır. Gönüllülük ruhu kaybedilmeden, uzman çalışanların destek verdiği etkin ve kurumsal bir yapı birçok STK'da başarılamamıştır

* Kurumlar finansal olarak sürdürülebilmekte zorlanmaktadirlar.

Kurum faaliyetlerinin kalıcı olarak sürdürülebilmesi ve faaliyetlerinin güçlenmesi için süreklilik gösteren finansal kaynaklara ihtiyaç vardır. Yapılan görüşmelerde birçok kurumun finansal düzeyde arzu edilen seviyeye gelmediği, finansal olarak kaynaklarını çeşitlendirip, güçlendiremediği tespit edilmiştir. Başlangıçta bireysel bağışçılarının kısıtlı destekleriyle 
küçük çaplı faaliyetler yapan birçok STK, günümüzde daha çok proje ve hibe destekleriyle çalışmalarını devam ettirmektedir. STK faaliyetlerinin ulusal ve uluslararası projelerle desteklenmesi, faaliyetlerini geliştirirken kurumsallaşmalarına da olumlu katkı sağlamıştır. Ancak kapsamı dar ve belirli bir zaman aralığı için yapılan proje destekleri, alternatif finansal kaynak arayışlarının azalmasına da neden olmuştur.

* Birçok STK'nın net olarak tanımlanmış bir faaliyet alanı yoktur.

Birçok STK eğitim, sosyal yardım, seminer, gezi gibi çok farklı alanda çocuk, genç, kadın, anne, yoksul, göçmen gibi değişen gruplar için çeşitli faaliyetlerde bulunmaktadırlar. Faaliyetlerdeki bu farklılaşma ve çeşitlilik, her ne kadar değişen toplumun ve ailenin ihtiyaçlarına cevap veriyor gibi görünse de STK'larda odak kaymasına neden olabilmekte; STK'ların asıl hedeflerinin zaman içinde unutulması riskini doğurmaktadır. Diğer taraftan belli bir odağı olmayan kurumlar yaptıkları faaliyetlerde yeteri kadar derinleşememekte ve arzu edilen toplumsal faydayı üretememe riskiyle karşı karşıya kalmaktadırlar.

* Kurumların bazılarında genç kalifiye gönüllü bulmakta s1kıntılar yaşanmaktadır.

STK temsilcilerinin önemli bir kısmı genç kalifiye elaman bulamadıklarını, gelenlerin kısa sürede kurum değiştirdiğini söylemektedirler. Bu sorun aslında Türkiye'deki birçok STK'da yaşanmaktadır. Daha çok gönüllü yapılan sivil toplum faaliyetlerinin maddi getirisi de oldukça düşük olmakta, birçok genç için cazip bir kariyer sunmamaktadır. Bununla birlikte toplumumuzda pek de yaygın olmayan gönüllülük ve gönüllü faaliyetlere katılım, STK'ların insan kaynağı bulmalarını da zorlaştırmıştır. Özellikle 15 Temmuz 2016'daki darbe girişimi sonrası yaşanan toplumsal travma, vatandaşların birçok sivil toplum kuruluşuna bakışlarını olumsuz etkilemiş olabilir. Ayrıca bazı STK'larda kurumsallaşmada yaşanan sorunlar, daha çok birkaç kişi üzerinden yürüyen faaliyetler ve STK faaliyetlerinin diğer gönüllülerle iş birliği içinde kapsayıcı bir biçimde her zaman yapılamaması, STK'lara daha geniş kapsamlı katılımı engellemektedir. Bunlardan ötürü 
gönüllülükle ilgili sorunlar hem makro ölçekteki sosyal, siyasi ve ekonomik gelişmelerden hem de kurumların kendi iç yapılarındaki sorunlardan kaynaklanmaktadır.

* Özellikle son yıllarda birçok STK, devlet ve uluslararası kurumlarla yakın ilișkiler geliștirmektedir.

Küreselleşmenin de bir boyutu olan yerel aktörler ve diğer paydaşlarla devletin yakın iş birliği geliştirmesi, son yirmi yılda artarak devam ediyor. Gerek ulusal ve uluslararası kurumlar tarafından düzenlenen faaliyetler, gerekse bu kurumların sağladığı proje ve hibeler, sivil toplum kuruluşlarının ulusal ve uluslararası çapta daha kapsamlı ve nitelikli çalışmalar yapmalarını sağlıyor. Ancak bu ilişki, devlet ve uluslararası kurumlar nezdinde sivil toplum kuruluşlarının her zaman kendi seslerini duyurmalarını ve kendi fikirlerini sunmalarını beraberinde getirmiyor. Çoğu zaman da kadına karşı şiddet, eğitim gibi sadece belirli alanlarda sınırları çizilmiş faaliyetler yapmalarını beraberinde getiriyor. Bu da ister istemez sivil toplumun çoğulcu yapısını destekler gibi gözüken finansal katkıların, sivil toplumu "hizaya sokmak" için kullanılmasına da neden olabiliyor. Mülakatta bazı STK temsilcilerinin özellikle bu konuyu gündeme getirmeleri ve kendi ajandalarından uzaklaştıklarını söylemeleri, demokrasi ve çoğulculuk açısından önemli bir mesele. Diğer taraftan belirli STK'ların siyaseten veya ideolojik olarak politika yapıcılar tarafindan tercih edilmesi veya faaliyetlerinin desteklenmesi ise birçok katılımcı tarafından eleştirilmiştir. Bazı STK'ların ulusal ve uluslararası proje destekleri alabilmek için oluşturduğu özel birimler varken, bazıları ise bu tarz destekleri planlı bir biçimde gündemlerine almamaktadır.

* Diğer STK'larla yapılan iş birlikleri istenilen düzeyde değildir.

Birçok STK temsilcisi devlet, akademi ve diğer STK'lar ile iş birliği yaptığını; ancak bunların kalıcı ve uzun soluklu birlikteliklere dönüssmediğini ifade etmiştir. Katılımcıların önemli bir kısmı daha etkili olabilmek ve toplumsal faydası yüksek projeler geliştirmek için başta STK'lar olmak üzere diğer kurumlarla iş birlikleri geliştirmek isterken, bazı katılımcıların ise bu konuda çok istekli ol- 
madıkları görülmüştür. Özellikle muhafazakâr ve seküler STK'ların ortak projeler geliştiremedikleri, benzer alanlarda faaliyet gösterseler de birbirlerine kuşkuyla yaklaştıkları bulunmuştur.

* Erkeklerin aile ve ilgili alanlarda sivil topluma katılımı oldukça düşüktür.

Aile odaklı çalışan STK'ların yöneticileri ve öne çıkan gönüllülerine göz atıldığında cinsiyet dağılımındaki uçurum kolaylıkla görülür. Araştırmaya katılan birçok katılımcı da bu sorunu dile getirmiş, erkeklerin aile meselesine yeteri kadar kafa yormadıklarını söylemiştir. Erkeklerin daha önemli görülen siyaset veya ticaret alanlarına odaklandıklarını, aileyi ise kadının omzuna yıktığı birçok katılımcı tarafında dile getirilmiştir. Özellikle muhafazakâr kesimden gelen birçok STK'nın kuruluş amacı ve ilk yıllarındaki faaliyetlerine bakıldığında, bu kurumlar daha çok kadınların "bilinçlenmesi", "iyi birer anne olması" ve kadınlar arası ilişkilerin düzenlenmesi için kurulmuştur. Bu çerçevede faaliyetleri daha çok kadına ve annelere hitap eden bu kurumalara erkeklerin uzak durması anlaşılabilir. Ancak gelinen noktada, erkeklerin bu kurumlarda aile ile ilgili faaliyetlerde görev alması gerektiği birçok katılımcı tarafından vurgulanmıştır.

* Geleneksel aileye ve aile değerlerine karşı artan tehditler olduğu birçok katılımcı tarafından vurgulanmıștır. Boşanma, sosyal medya bağımlılığı, iş-yaşam dengesine dair sorunlar, babaların annelere yeterli destek sunmamaları ve farklı birliktelik türleri sıklıkla aileye dair öne çıkan riskler olarak vurgulanmıștır.

Her ne kadar farklı katılımcıların farklı sorun tespitleri olsa da televizyon, internet ve sosyal medya bağımlılığı, eşler ve çocuklar arası ilişkilerdeki sorunlar, boşanma, sağlık ve yaşlanmaya dair riskler tüm katılımcılar tarafından öne çıkan sorun alanlarını oluşturmaktadır. Bununla birlikte kadına karşı şiddet, uyuşturucu bağımlılığı, kadın ve erkek arasındaki eşitsizlik de birçok katılımcı tarafindan dile getirilmiştir. Özellikle muhafazakâr STK'lar homoseksüel ilişkilerin medya ve belirli gruplarca normalleştirilmeye çalışıldığını ifade ederek, bu birlikteliklerin de aile kurumunu olumsuz etkilediğini dile 
getirmişlerdir. Yine bu çerçevede İstanbul Sözleşmesi birçok muhafazakâr STK temsilcisi tarafindan eleştirilmiştir. Özellikle gençler arasında evlilik dışı birlikte yaşam, bunun sosyal medya ve televizyon yoluyla olağanlaştırılması muhafazakâr STK'lar tarafından başlıca tehditler arasında dile getirilmiştir. Ayrıca kadına karşı şiddetin önlenememesi de öne çıkan sorun alanlarından biri olarak hemen hemen tüm STK'larca belirtilmiştir. Yoğun göç dalgasıyla birlikte gelen toplumsal değişim, genç Suriyelilerle yapılan evlilikler ve bunun aile üzerindeki riskleri de bazı katılımcılar tarafından vurgulanmıştır.

* $\quad$ Aile ile ilgili konularda kadının yalnız bırakılması sıklıkla dile getirilmektedir.

Erkeklerin ev işleri ve çocuk yetiştirmede kadınlara yeteri kadar destek vermedikleri, aileye dair konularda kadınları yalnız bıraktıkları birçok katılımcı tarafından sıklıkla vurgulanmıştır. Kadının istihdama katılımıyla birlikte üzerindeki yükün arttığını ancak bunun erkekler tarafından yeterli ölçüde paylaşılmadığını bilimsel çalışmalar da göstermektedir. Bu noktada ciddi psikolojik ve fiziksel sorunlar yaşayan kadınların iş-aile dengelerinde de bozulmalar olmakta, yaşanan sorunlar başta çocuklar olmak üzere tüm aile üyelerini olumsuz etkilemektedir. $\mathrm{Bu}$ çerçevede bazı katılımcılar eşlere ve ailelere verilecek eğitimlerin önemini vurgularken bazıları bu cinsiyet eşitliğinin daha ilkokul yıllarında öğretilmesinin önemine dikkat çekmişlerdir.

* CCalışmaya katılan tüm katılımcılar her türlü aksaklıklarına rağmen ailenin ve onun bireyi koruyucu özelliğinin toplumumuzun güçlü yönlerinden biri olduğunu ve korunması gerektiğini vurgulamaktadır.

Farklı siyasi görüşlere sahip sivil toplum yöneticileri günümüzün artan ekonomik ve sosyal sorunları da dikkate alındığında ülkemizde ailenin hala sığınılacak bir liman olduğuna, her türlü sorunlu yapısına rağmen ailenin korunması ve güçlendirilmesi gerektiğine vurgu yapmışlardır. Her kesim tarafindan benimsenen bu olumlu tutum, ileriye dönük kapsayıcı aile politikaları üretilmesi ve tüm aileleri etkileyen sorunlara ortak çözümler bulunması adına ümit vericidir. 
Mülakat bulguları ışığında aile ve sivil toplum kuruluşlarına dair genel öneriler aşağıdaki gibi sıralanabilir:

* $\quad$ Aile kurumunun toplumun önemli bir parçası olduğu unutulmadan, toplumsal değişimin getirdiği firsatlar ve riskler doğru anlaşılarak, değişen toplumun ve ailenin ihtiyaçlarını dikkate alan politikalar ve faaliyetler geliştirilmelidir.

Ailenin anne, çocuk, yaşlı demeden bir bütün olduğu ve ailedeki fertlerin tamamının ihtiyaçlarını dikkate alan bütüncül planlamalarla faaliyetlerin yapılması gerektiği unutulmamalıdır. Bu bütüncül politikalara ek olarak engelli, tek ebeveynli, yaşlı, yoksul vb. dezavantajlı ailelerin ihtiyaçlarını gözeten özel faaliyetler de ihmal edilmemelidir.

* STK'larda gönüllülük ruhu zedelenmeden bu kurumların profesyonelleşmesi önemlidir. Bunun için gerekli olan kurumsal altyapı sağlanmalıdır.

* STK'ların finansal olarak sürdürülebilir hale gelmesi, kaynaklarını çeşitlendirmesi ve tek bir finansal kaynağa bağlı kalmaması, sivil toplum kuruluşlarının sürekliliği için hayati önem taşımaktadır.

* STK'lar her alanda farklı faaliyetler düzenlemek yerine çalışma odaklarını netleştirmeli ve bu odaklarda derinleşmelilerdir. Önceden belirlenmiş açık amaçlar doğrultusunda faaliyetler düzenlemeli, bunların çıktılarını ise sistemli bir biçimde analiz etmelidirler.

* STK'lar hem kendi aralarında hem de devlet, piyasa ve uluslararası kurumlar ile daha etkin iş birlikleri kurmalıdırlar.

* $\quad$ STK'lar kuruluş gayeleri çerçevesinde ulusal ve uluslararası çevrelerde daha aktif lobi faaliyetleriyle aileye dair meselelerde kamuoyu oluşturmalı, sorunlu gördükleri meseleleri gündemde tutmalı ve bu sorunların çözümünde aktif destek sunmalidirlar. 


\section{KAYNAKÇA}

ACEV 2017. Türkiye'de İlgili Babalık ve Belirleyicileri, İstanbul: AÇEV Yayınları.

Acar, H. (2008). “Türkiye’de Ulusal Gençlik Politikası Nasıl Yapılmalıdır?” Uluslararası İnsan Bilim Dergisi.

Adak, N. (2007). "Kadınların İkilemi: İş ve Aile Yaşamı." Sosyoloji Dergisi Ülgen Oskay’a Armağan Özel Sayısı.

Akçeşme, F. (2013). "Sivil Toplum ve Türkiye Cumhuriyet'indeki Yeri.” HAK-İS Uluslararası Emek ve Toplum Dergisi, 202-225.

Arpacı, F. ve Ersoy, A.F. (2007). "Kadının Çalışmasının Ailenin Yaşam Kalitesine Etkisinin İncelenmesi." Aile ve Toplum Eğitim Kültür ve Araștırma Dergisi, 11.

Aydın, D. A. (1996). “Çocuğun Dini Şahsiyet Kazanmasında Ailenin Önemi.” Ondokuz Mayıs Üniversitesi İlahiyat Fakültesi Dergisi, 211-220.

Balaban, Y. A., İnce Ç. İ. (2015).” Gençlerin Sivil Toplum Kuruluşlarındaki Gönüllülük Faaliyetleri ve Gönüllülük Algısı: Türkiye Eğitim Gönüllüleri Vakfi (TEGV) Örneği.” Dokuz Eylül Üniversitesi, İktisadi ve İdari Bilimler Fakültesi Dergisi, Cilt:30, Sayı:2, s. 149-169.

Belligüçük, F. (2004). "Medyanın Aile Kurumu Açısından Eleştirel Okuması: Biz Evleniyoruz Programı Örneği.” Aile ve Toplum. 6 (2).

Bener, Ö. (2009). “Ev Kadınlarının Çalışma Yaşamına Katılım Konusunda Görüşlerinin STK'ların Yürüttüğü Kadın İstihdamı Faaliyetleri Çerçevesinde Değerlendirilmesi." Uluslararası İnsan Bilimleri Dergisi, Cilt:6, Say1:1.

Çiftçi, O. (1991). "Çocuğun Sosyalleşmesinde Ailenin Rolü.” Aile ve Toplum Dergisi. 2(2). 
Demirkan, S. (2006). "Türk Ailesinin Korunması ve Güçlendirilmesinde Sivil Toplum Kuruluşları ile İşbirliğinin Önemi.” Aile ve Toplum, Cilt: 3 Say1: 9. 91-96.

DPT (1989) “Türk Aile Yapısı Özel İhtisas Komisyonu: Altıncı Beş Yıllık Kalkınma Planı Özel İhtisas Komisyonu Raporu." Türk Başbakanlık Devlet Plânlama Teşkilâtı, Ankara.

Duggan, M., Lenhart A. ve Ellison N. (2015). "Parents and Social Media." Pew Research Center. 1(10).

Ekici, F.Y. (2014). Türk Aile Yapısının Değişim ve Dönüşümü ve $\mathrm{Bu}$ Değişim ve Dönüşüme Etki Eden Unsurların Değerlendirilmesi." The Journal of Academic Social Science Studies, (30).

Eröz, M. (1991). Türk Ailesi: Aile Yazıları I. Ankara: Başbakanlık Aile Araștırma Kurumu Yayınları.

Greenfield, P. (2014). Mind and Media. New York: Psychology Press.

Gül, S. S., Özen B., Kahya Ö. (2017). “Morçatı ve Şefkat-Der Örneğinde Kadına Yönelik Şiddetle Mücadelede Sivil Toplumun Rolü.” SDÜ Fen-Edebiyat Fakültesi Sosyal Bilimler Dergisi, Say1: 42, s. 199-226.

Günay, G. ve Bener, Ö. (2011). “Kadınların Toplumsal Cinsiyet Rolleri Çerçevesinde Aile İçi Yaşamı Algılama Biçimleri.” Türkiye Sosyal Araștırmalar Dergisi, (3).

Hochschild, A., \& Machung, A. (2012). The Second Shift: Working Families and The Revolution at Home, Penguin.

Kafesoğlu, İ. (1997). Türk Milli Kültürü. İstanbul: Ötüken Yayınları.

Kaya, S. (2018). "Kadın ve Sosyal Medya." Gaziantep University Journal of Social Sciences. 17 (2). 563-576.

Kaypak, Ş. (2015). “Devletten Yerel Yönetime Değişim Sürecinde Sivil Toplumun Yeni Yüzü.” Bitlis Eren Üniversitesi Sosyal Bilimler Dergisi, 34-57.

Keser, H. ve Hışım, S. (2016). “Demokrasilerde Sivil Toplumun Rolü.” İnönü Üniversitesi Hukuk Fakültesi Dergisi, 201-224.

Kıray, M.B. (1999). Toplumsal Yapı ve Toplumsal Değişme. İstanbul: Bağlam Yayınları. 
Nalini R. \& K. Krishnakumar K. (2017). "Status Of Women Employees In Ngos: A Qualitative Analysis.” Research on Humanities and Social Sciences, Vol. 7, No.17.

Kuzucu, Y. (2011). "Değişen Babalık Rolü ve Çocuk Gelişimine Etkisi.” Türk Psikolojik Danışma ve Rehberlik Dergisi. 4(35).

Petrikova Ivica (2015) "NGO Effectiveness: Evidence from the Field of Child Labour in El Salvador." Forum for Development Studies, 42:2, 225-244, DOI: 10.1080/08039410.2015.1010567

Rosy, S. Y. Sabiha Yeasmin Rosy (2016). "Bangladeshi Women Trafficking Survivors Situation in Family and Society: NGO Response towards their Reintegration." Multidisciplinary Journal of Gender Studies. 5(1), 911-928. doi: 10.4471/generos.2016.1572.

Sloat, Amanda. (2005). "The Rebirth Of Civil Society: The Growth Of Women's Ngos in Central and Eastern Europe." European Journal of Women's Studies. 12:437. DOI: 10.1177/1350506805057100.

Strydom, M. (2010). "The Implementation of Family Preservation Services: Perspectives of Social Workers at NGOs." Social Work/Maatskaplike Werk, 46(2).

Sunar, L. (2018). Türkiye'de İslami STK’ların Kurumsal Yapı ve Faaliyetlerinin Değişimi. İstanbul: İLKE İlim Kültür Eğitim Derneği.

T.C. Başbakanlık Aile Araştırma Kurumu Başkanlığı, (2002). 2001 Yilı Aile Raporu.

T.C. İçişleri Bakanlığı Sivil Toplumla İlişkiler Genel Müdürlüğü, (2020). Derneklere İlişkin İstatistikler. https://www.siviltoplum.gov.tr/ dernek-sayilari/.

T.C. Vakıflar Genel Müdürlüğü, (2019). Yeni Vakıfların Hedef Kitlesi 2017. https://www.vgm.gov.tr/.

Talas, M. (2011). "Sivil Toplum Kuruluşları ve Türkiye Perspektifi." TÜBAR, 29, 337-401.

Terzioğlu, G. (1988). “Kadınların Evle İlgili Günlük Faaliyetlerinin Değerlendirilmesi.” Ev Ekonomisi Dergisi. 
Tuncay, S. (2000). “Türkiye'de Gençlik Sorunlarının Psikolojik Boyutu.” Muğla Üniversitesi SBE Dergisi.

Van Huyssteen, J., \& Strydom, M. (2016). “Utilising Group Work in The Implementation of Family Preservation Services: Views of Child Protection Social Workers." Social Work. 52(4), 546-570.

Yentürk, N., Kurtaran, Y., Uran, Ş., Yurttagüler, L., Akyüz, A., Nemutlu, G., (2006). "İstanbul Gençliği-STK Üyeliği Bir Fark Yaratıyor mu?” İstanbul Bilgi Üniversitesi STK Eğitim ve Araștırma Birimi, İstanbul Bilgi Üniversitesi Gençlik Çalışmaları Birimi, Gençlik Çalışmaları Araştırma Raporları 1

Ylldırım, M. (2013). “Sivil Toplum ve Devlet.” Cumhuriyet Üniversitesi Sosyal Bilimler Dergisi. 27(2), 226-242. 
